\title{
From Drawn to Printed Model Book: Jacques Androuet Du Cerceau and the Transmission of Ideas from Designer to Patron, Master Mason and Architect in the Renaissance
}

\author{
Myra Nan Rosenfeld
}

Volume 16, numéro 2, 1989

Études sur l'architecture et son environnement

Studies on Architecture and its Environment

URI : https://id.erudit.org/iderudit/1073144ar

DOI : https://doi.org/10.7202/1073144ar

Aller au sommaire du numéro

\section{Éditeur(s)}

UAAC-AAUC (University Art Association of Canada | Association d'art des universités du Canada)

ISSN

0315-9906 (imprimé)

1918-4778 (numérique)

Découvrir la revue

Citer cet article

Rosenfeld, M. N. (1989). From Drawn to Printed Model Book: Jacques Androuet Du Cerceau and the Transmission of Ideas from Designer to Patron, Master Mason and Architect in the Renaissance. RACAR : Revue d'art canadienne / Canadian Art Review, 16(2), 131-145. https://doi.org/10.7202/1073144ar

\section{Résumé de l'article}

L'invention de l'impression par caractères mobiles par Johannes Gutenberg à Mayence vers 1455 transforma radicalement la fabrication du livre et par conséquent permetta à l'auteur de présenter ses idées à un plus large publique. Quand on regarde de plus près le développement du livre d'architecture imprimé et illustré en France pendant la Renaissance, une des personnages les plus importantes fût Jacques Androuet Du Cerceau (Paris, vers 1520-Paris vers 1586). Dans l'article suivant, l'auteur propose d'analyser la contribution de $\mathrm{Du}$ Cerceau à la diffusion de modèles d'architecture au mécène, au maître maçon, et à l'architecte. Le métier de l'architecte était en pleine évolution. L'invention de l'impression par caractères mobiles et de la gravure contribuèrent à élever le niveau de connaissances du maître maçon qui devenait ainsi un architecte. Pour que le bâtiment pût être bien conçu, il fallait que le mécène fût aussi bien instruit que le maître maçon et architecte.

Deux recueils de gravures conservés à la bibliothèque du Centre Canadien d'Architecture, Détails d'ordres d'architecture, grand format et Temples et habitations fortifiés, nous montrent combien l'invention de l'impression par caractères mobiles et de la gravure apportèrent une nouvelle cohérence à l'éducation du maître maçon ainsi qu'à celle du mécène. En outre, la suite des Temples de habitations fortifiés met en évidence la grande connaissance de la part de Du Cerceau de l'architecture romaine et de l'architecture italienne contemporaine qu'il a connues grâce à un voyage à Rome entrepris entre 1530 et 1540 et par l'intermédiare de carnets de dessins qu'il a lui-même transformés en receuils de gravures.
Tous droits réservés @ C UAAC-AAUC (University Art Association of Canada | Association d'art des universités du Canada), 1989
Ce document est protégé par la loi sur le droit d'auteur. L’utilisation des services d'Érudit (y compris la reproduction) est assujettie à sa politique d'utilisation que vous pouvez consulter en ligne.

https://apropos.erudit.org/fr/usagers/politique-dutilisation/ 


\title{
From Drawn to Printed Model Book: Jacques Androuet Du Cerceau and the Transmission of Ideas from Designer to Patron, Master Mason and Architect in the Renaissance
}

\author{
MYRA NAN ROSENFELD
}

For Janet Byrne and Phyllis Lambert

\section{RÉSUM É}

L'invention de l'impression par caractères mobiles par Johannes Gutenberg à Mayence vers 1455 transforma radicalement la fabrication du livre et par conséquent permetta à l'autcur de présenter ses idées à un plus large publique. Quand on regarde de plus près le développement du livre d'architecture imprimé et illustré en France pendant la Renaissance, une des personnages les plus importantes fût Jacques Androuet Du Cerceau (Paris, vers 1520-Paris vers 1586). Dans l'article suivant, l'auteur propose d'analyser la contribution de Du Cerceau à la diffusion de modèles d'architecturc au mécène, au maître maçon, et à l'architectc. Le métier de l'architecte ćtait en pleine évolution. L'invention de l'impression par caractères mobiles et de la gravure contribuèrent à élcver le niveau de connaissances du maître maçon qui devenait ainsi un architecte. Pour que le bâtiment pût être bien conçu, il fallait que le mécène fût aussi bien instruit que le maître maçon et architecte.

Deux recueils de gravures conservés à la bibliothèque du Centre Canadien d'Architecture, Détails d'ordres d'architecture, grand format et Temples et habitations fortifiés, nous montrent combien l'invention de l'impression par caractères mobiles et de la gravure apportèrent une nouvelle cohérence à l'éducation du maître maçon ainsi qu'à celle du mécène. En outre, la suitc des Temples de habitations fortifiés met en évidence la grande connaissance de la part de Du Cerceau de l'architecture romaine et de l'architecture italienne contemporaine qu'il a connues grace à un voyage à Rome entrepris entre 1530 et 1540 et par l'intermédiare de carnets de dessins qu'il a lui-même transformés en receuils de gravures.
The invention of printing in the middle of the fifteenth century revolutionized the way in which ideas were transmitted thereby making it possible for writers to reach a mass audience. It is generally agreed that Johannes Gütenberg issued the first book printed with moveable type, his threevolume, forty-two-line Bible, at Mainz in 1455. Soon after, printing presses with moveable type were established in other European countries. ${ }^{1}$

1 Lucien Febvre and Henri-Jean Martin, The Impart of Printing 1450-1800, The Coming of the Book, trans. Daniel Gerard, ed. G. Nowell-Smith and David Wootton, 2nd English ed. (London, 1984), 46-56; Henri-Jean Martin, "La révolution de l'imprimé," in Histoire de l'édition
During the fifteenth and sixteenth centuries, there was still a close relationship between the printed book and the traditional handmade manuscript. Publishing houses continued to make manuscript copies of the same texts they produced in printed books. Moreover, the layout of the printed book took over many characteristics of the hand-made manuscript. ${ }^{2}$

française, ed. Henri-Jean Martin, Roger Chartier, and Jean Vivet (Paris, 1982), I, 145-61

2 Sandra Hindman and James Douglas Farquhar, Pen to Press: Illustrated Manuscripts and Printed Books in the Firs Century of Printing (Baltimore, 1977), 101-56; M. LehmannHaupt, "The Heritage of the Manuscript," in P. Hofer, $A$ History of the Printed Book (New York, 1938), 2-23. 
In France, the first printing press with moveable type was established in Paris at the Sorbonne by the humanists Guillaume Fichet and Jean Heynlin. Their initial venture was the 1470 edition of the Lettere of Gaspari de Bergamo. By the early 1480 s, books were published with woodcut and engraved illustrations. Antoine Vérard, one of the most important Parisian publishers of the time, had a large clientele consisting of nobles and members of the royal family for whom he commissioned luxury manuscript copies on vellum of the same printed and illustrated books he produced. ${ }^{3}$ Printing presses and publishing houses were established by the 1490s in 30 of the major commercial, university, and governmental centres in France. ${ }^{4}$ The book became a commodity, and wealthy businesspeople hired printers and designers as well as scholars to work for them. ${ }^{\bar{j}}$

When we turn to the production of illustrated books on architecture, a key figure in sixteenthcentury France was Jacques Androuet Du Cerceau. His workshop produced books and manuscripts on architecture, furniture, ornament, perspective, and geometry, maps, and suites of engravings, etchings, and drawings in which figurative compositions as well as buildings were depicted. ${ }^{6}$ Du Cerceau's intention that his publica-

3 Jeanne-Marie Dureau, "Les premiers ateliers français," in Histoire de l'édition, ed. Martin, Chartier, and Vivet, 16375; Albert Lamarre, "I.es incunables : la présentation du livre," in Histoire de l'édition, ed. Martin, Chartier, and Vivet, 195-216; for Antoine Vérard, see Dominique Coq, "L.es incunables : textes anciens, textes nouveaux," in $\mathrm{His}$ toire de l'édition, ed. Martin, Chartier, and Vivet, and Febvre and Martin, Impact of Printing, 120-21. One of the first illustrated books printed in France was the Mirroir de la rédemption de l'humain lignage, published in 1478 in Lyon using woodcut illustrations from an earlier German edition published in Basel in 1476. Among the earliest illustrated books printed in Paris were the Missale Parisiense and the De Casibus mulieribus by Boccaccio, printed in 1481 and 1483 respectively, by Jean Dupré. The Missale was published with engraved illustrations.

4 Dureau, "Les premiers ateliers," 164.

5 Febvre and Martin, Impact of Printing, 117-20. One such entrepreneur, Barthélemy Buyer, the son of a wealthy lawyer and member of the City Council of Lyon, invested in publishing houses in Lyon, Paris, and Toulouse and had business contacts with other publishers in Venice, Germany, and Spain.

6 The first attempt to write a monograph on Jacques Androuet Du Cerceau and his family was carried out by Henry de Geymüller, Les Du Cerceau, leur vie et leur oeuvre (Paris and London, 1887). Geymüller's work is fundamental, but needs to be updated. There is a definite need for a new catalogue raisonné of Du Cerceau's prints and drawings, since many of the items in Geymüller's book have changed location, attribution, number of folios, and dimensions. Geymüller did not have the advantage of modern photography and did not compare the various states of the suites or editions of books in different collections. Du Cerceau's oeuvre will be re-examined in an exhibition to be organized by the CCA: Theory and Practice, French Publications on Architecture, 1500-1650. tions be used by an audience drawn from many levels of society is clearly expressed on the title page of the first French edition of his Livre d'architecture, published in Paris in 1559:

Parallèlement à l'imitation des dicts plans \& desseigns. non seulement les maçons, charpentiers, \& autres ouvriers, mais aussi ceux, qui se delectent à la pourtraicture, peuvent prendre instruction à bien desseigner $\&$ accomoder tous logis \& bastiments, chosc qui apporte grand plaisir \& proffit.

When Du Cerceau refers to both the profit and pleasure derived from the perusal of this book, he is obviously referring to its function both as a model book for masons and architects and as a picture book for patrons. Of course, Du Cerceau was closely following the examples of Albrecht Dürer and Sebastiano Serlio, who had written the first original practical manuals on architecture with woodcut illustrations published in Europe in a vernacular language. Dürer's Etliche Underricht zu Befestigung der Stett, Schloss und Flecken, first published in Nuremberg in 1527, was republished in Latin in Paris in 1535 as De Urbibus arcibus castellisque. Serlio's Book Iv, Regole generale di architettura (On the Orders), the first instalment of his manual, was published in Venice in 1537. His second instalment, Book III, Il terzo libro (On Antiquity), dedicated to King Francis I of France, was published in Venice in March of 1540, just before Serlio left Italy for France in 1541 to take up permanent residence as royal architect. Serlio published Books I and II, Il primo [secondo] libro (On Geometry and Perspective), in Paris in 1545, Book v, Quinto libro d'architettura (On Churches), in Paris in 1547, and the Libro extraordinario (On Doors) in Lyon in 1551. This later book had engraved illustrations separated from the short text. Engravings, which could not be integrated with letterpress as easily as woodcuts could, began to be used frequently in books only towards the middle of the sixteenth century. ${ }^{8}$

7 Jacques Androuet Du Cerceau, Livre d'architecture (Paris: Benoît Prévost, 1559; cCA Library, X0006179). See Geymüller, Les Du Cerceau, 319; Jacques-Charles Brunet, Manuel du libraire et de l'animateur de livres, I, I $1^{\mathrm{e}}$ partie (Paris, 1860), 280; Ruth Mortimer, Harvard College Library, Department of Printing and Graphic Arts, Catalogue of Books and Manuscripts, Part 1: French 16th Century Books (Cambridge, Mass., 1964), no. 22, 27. A Latin edition of the same book, De Architectura, was also published by Benoît Prévost in the same year (cCA Library, 87-86091)

8 Myra Nan Rosenfeld, Sebastiano Serlio, On Domestic Architecture (New York and Cambridge, Mass., 1978), 37. The first illustrated book on architecture published in France was Dicgo de Sagredo's Medidas del Romano (Toledo, 1526), which was reprinted as Raison d'architecture antique (Paris, 1527). For the use of engraved illustrations with letterpress, see Robert Brun, Le livre français illustré de la Renaissance (Paris, 1969), 95-102. The cca Library has the first editions of the German and Latin versions of Dürer's 
Du Cerceau's role in his enterprise has been the source of much confusion. In a pioneering article published in 1977, Janet Byrne proposed that Du Cerceau should be considered a publisher who directed a large workshop consisting of designers, draughtsmen, and printers. As Byrne has noted, Du Cerceau must have provided the original designs and had the members of his workshop execute the books, drawings, and prints in a massproduction fashion. There must have been a division of labour with some artists drawing outlines, others adding wash, some engraving the plates, and others printing them. This workshop practice, common in scriptoria in the Middle Ages, makes it almost impossible for the art historian to identify those drawings and prints actually executed by Du Cerceau himself. ${ }^{9}$ In addition, Du Cerceau sometimes contracted his books out to other printers and publishers. ${ }^{10}$

Janet Byrne's suggestion that Jacques Androuet Du Cerceau should be considered a businessmanentrepreneur as well as a designer is supported by documents recently published by David Thompson. Du Cerceau's father, Yves Androuet Du Cerceau, was identified as a wine merchant in an inventory of his possessions drawn up in Paris on 23 March 1546, just after his death. ${ }^{11}$ In addition to publishing several suites of engravings on ornament and on architecture in Orléans between 1549 and 1551, Jacques Androuet Du Cerceau himself was also active as a wine merchant. He is mentioned on 16 October 1557 as owning a vineyard in Orléans and in May 1558 was involved in a commercial transaction involving the sale of wine

book (8216 and POX16811), the first edition of the French version of Sagredo's book (86-B16092), and the first editions of all of Serlio's books except for Book IV, which it has in the second Venetian edition of 1540 (X0006181, WX191, and 86B16809).

9 Janet Byrne, "Een Zeldam ornament boekje uit het atelier van Jacques Androuet Du Cerceau," Bulletin van het Rijksmuseum, xxv, 1 (1977), 3-15, English summary, 45-49. See other articles by Byrne on Du Cerceau where she takes a similar point of view: "Jacopo della Nave or Jacques Androuet Du Cerceau," Metropolitan Museum Journal, viI (1973), 143-49; "Some Attributions Undone," Master Drawings, xIII, no. 3 (1975), 240-49, pls. 16-21; "Du Cerceau Drawings," Master Drawings, xv, no. 2 (1977), 147-61, pls. 9-17; and "Some Sixteenth-Century Designs for Tombs and Fountains in the Metropolitan Museum," Master Drawings, XXI, no. 3 (1983), 263-70, pls. 11-27b.

$10 \mathrm{See}$, for instance, the first editions of Petit traité des cinq ordres de Colonnes (Paris, Pour Jacques Androuet Du Cerceau, 1583; cCA Library, 85-B3155); Leçons de perspective positive (Paris, Par Marmert Patisson Imprimeur, 1576; CCA Library, X372), and Livres des édifices antiques romans (Paris, Par Jacques Androuet Du Cerceau, 1584; CCA Library, 88-B6841).

11 David Thompson, Androuet Du Cerceau, les plus excellents bastiments de France, trans. Catherine Ludet (Paris, 1988), 310 , Archives Nationales, Paris, Minutier Centrale, CxxII, 56 . in Paris. ${ }^{12}$ The profession of architect was in a state of evolution during the first half of the sixteenth century. Du Cerceau was called "pourtrayeur" and "architecte" in documents of 28 June 1545 and 23 March 1546. ${ }^{13}$ These titles were references to the fact that he played a role primarily as a designer and draughtsman rather than as practising architect in the modern sense like his sons Baptiste Androuet Du Cerceau and Jacques Androuet Du Cerceau, the Younger, who were responsible for supervising the construction of their buildings as well as designing them. Jacques Androuet Du Cerceau must have been trained as an engraver or as a draughtsman rather than as a master mason. In addition to his activity as a publisher, Jacques Androuet Du Cerceau must have been called on to execute drawings of buildings designed either by himself or by others for patrons, contractors, and designers. On other occasions he is documented as being employed as an expert consultant. ${ }^{14}$

12 Thompson, Les plvs excellents bastiments, 311, A.N. M.C., xxxili, 42. The reference for the second document of 1558 is given only as P. Renouard, Imprimeurs et libraires Parisiens $d u X X V I^{e}$ siècle (Paris, 1964), I, 94, Archives Natiotionales, $\mathrm{Z}(\mathrm{lH}) 49$, folio 50 verso. The most important of the suites with engraved title pages that indicate date and place of publication are: The Arcs, Iacobus Androveitus $d u$ Cerceau. Lectoribus.s. En vobis candidi lectores et architectvrae studiosi quinque et viginti exempla Arcum ... (Orléans, 1549; New York, Metropolitan Museum of Art, Department of Prints and Photographs, 39.95.1); the Fragments Antiques, Iacobus Androvetivs Dvcerceau. Lectoribus. s. cum natus essem dvodecim fragmenta structurae veteris commendata monumentis a Leonardo Theodorico... (Orléans, 1550; New York, Metropolitan Museum of Art, Department of Prints and Photographs, 20.82, 31.74.2, and 48.13.4); the Moyens Temples, Iacobvs Androvetius du Cerceau. Lecotoribus.s Qvoniam apvd veteres alio structurae. Genere Templa... (Orléans, 1550; New York, Metropolitan Museum of Art, Department of Prints and Photographs, 20.82); the Petites grotesques, Jacobus Androvetius dv Cerceau. Lecotoribvs. s. Nihil alivd semper cogitanti et molienti mihi, quam vt promissa ex solverem quod testantur satis superiores nostri labores... (Orléans, 1550; cCA Library, WX6218); the Vues d'optique, Iacobus Androvetivs dv Cerceau. Lecotoribus. s. Veteri consvetudine institvquve nostro novos subindè (Orléans, 1551 New York, Metropolitan Museum of Art, Department of Prints and Photographs, 49.46.55-60, 59.599.1-2, and 58.581.1); see Geymüller, Les Du Cerceau, 302, 300, 307, 316,300 , respectively, and D. Guillmard, Les maîtres ornemanistes (Paris, 1880; reprint ed., Amsterdam, 1968), 10-13; André Linzeler, Bibliothèque Nationale, Département des estampes. Inventure du fonds français. Graveurs du Seizième siècle, I (Paris, 1932), Ed. 2i, 68-69, Ed. 2b, 55, Ed. 2c, 56-57. Ed. 2g, 67-68, Ed. 2d, 60-61, respectively.

13 Thompson, Les plus excellents bastiments, 310, document of 23 March 1546, cited above in note 11: "pourtrayeur demeurant à tours." Document of 28 June 1545, "maistre Jacques Androuet, Architecte," A.N., xia, 1556, f. 124r, in Thompson, Les plus excellents bastiments, 310 .

14 Thompson, Les plus excellents bastiments, 312, 30 August 1581, Archives Municipales de Montargis, CC II. Du Cerceau was asked to inspect the bridge and two gates of the fortified walls of Montargis. 
Du Cerceau enjoyed royal and aristocratic patronage for his publishing endeavours. On 28 June 1545, he was given protection by King Francis I for three years against the copying of "ouvraiges et figures d'architecture, cornices, moresques, et compartiments." ${ }^{15}$ By 1 September 1546, he was under the protection of Marguerite d'Angoulême, Queen of Navarre and sister of Francis I, since in a document regarding the death of his father in that year Du Cerceau was called "Architecteur de la Royne de Navarre, demeurant à Orléans." During the same years, Marguerite de Navarre was also the patroness of Sebastiano Serlio, since she had been paying him an annual stipend in Venice since 1 January 1540 before he came to France. ${ }^{16}$ Du Cerceau's other royal patrons included King Henry II; Renée de France, Duchesse de Ferrare $;{ }^{17}$ her daughter Anne d'Este and son-in-law Jacques de Savoie, Duc de Nemours; ${ }^{18}$ King Henry III; Queen Catherine de Medici; and King Charles Ix. ${ }^{19}$

15 See note 13.

16 David Thompson, Jacques Androuet Du Cerceau, the Elder: A Profile of a French Architectural "Vulgarisateur" of the Sixteenth Century (unpublished $\mathrm{PhD}$ thesis, London University, 1975), 14, A.N., M.C., viII, 168, 1546. Rosenfeld, Sebastiano Serlio, 20; Serlio's Book v, On Churches, published in Paris, was dedicated to Marguerite de Navarre, who died on 21 December 1549.

17 For Renée de France and King Henry II, see Thompson, Les plvs excellents bastiments, 5, 8, 310,311, and Jacques Androuet Du Cerceau, 18-19, 25-30. Jacques Androuet Du Cerceau is mentioned in documents pertaining to Renée de France at Montargis from 1564 to 1575 , the year she died. One of his tasks was to distribute alms for her. The first edition of the Livre de grotesques, known as the Grandes grotesques (Paris: André Wechel, 1566), was dedicated to Renée de France (CCA Library, 85-B18281 and 88-B6841). Thompson has also noted a document in the Archives du Loiret, now destroyed, of 21 July 1551, mentioning that Du Cerceau was involved in the design of the Entry of Henry II into Orléans on 14 August 1551. The first edition of Du Cerceau's Livre d'architecture of 1559 was dedicated to King Henry II.

18 See Thompson, Les plus excellents bastiments, 8, 122-23, and Jacques Androuet Du Cerceau, 27, 30-32. The design of the Château of Verneuil-sur-Oise, illustrated in Les plus excellents bastiments de France, which belonged to Anne d'Este and Jacques de Savoie, has been attributed to Du Cerceau with no documentary evidence. The Livre des edifices antiques romains, published in 1584, was dedicated to Jacques de Savoie.

19 The first edition of the Second livre d'architecture, published in Paris in 1561, is dedicated to King Charles Ix (cCA Library, 85-B18281). The two volumes of the first edition of Les plvs excellents bastiments de France, published in Paris in 1576 and 1579, and the Leçons de perspective positive of 1576 are all dedicated to Catherine de Medici. See Lawrence Hall Fowler and Elizabeth Baer, The Fowler Architectural Collection in the Johns Hopkins Library (Baltimore, 1961), 19; Geymüller, Les Du Cerceau, 312; Renouard, Imprimeurs, I, 97; and Guillmard, Les maîtres, 14, all of whom have noted the existence of a 1572 edition of the third Livre d'architecture dedicated to Charles Ix. The CCA Library owns the 1582 edition (85-B3181) dedi-
Knowledge of Jacques Androuet Du Cerceau's life is fragmentary. He was born around 1520, but there is no record of his existence before the document of 28 June 1545 giving him royal protection. From 23 March 1546 to 16 October 1557, he is recorded as living in Tours and Orléans, and from May 1558 to 1564 he appears to have lived in Paris. It seems to have been after his move to Paris that Du Cerceau began to publish books on architecture. Until his Livre d'architecture appeared in Paris in 1559, his suites of etchings and engravings published in Orléans carried only a title page. Du Cerceau was a Protestant, and after the 1563 Edict of Amboise, which forbade Protestant meetings in Paris, he must have moved to Montargis where he was patronized by Renée de France. He is mentioned intermittently in documents at Montargis from 1565 until 1581. Renée de France, who died in 1575, was, like Queen Marguerite de Navarre, a sympathizer with the Protestant cause. ${ }^{20}$ Du Cerceau's exact place of residence from 1581 to 1586 is not known. He was dead by February 1586 when his possessions were divided among his children in Paris. ${ }^{21}$

The Canadian Centre for Architecture owns a rich and varied collection of printed books, suites of engravings, and manuscripts by Jacques Androuet Du Cerceau and his workshop. ${ }^{22}$ One

cated to Henry III. The attribution of the design of the Château de Charleval, illustrated in Les plus excellents bastiments de France, and built for Charles Ix, is not based on any documentary evidence. See Thompson, Les plus excellents bastiments, 208-209.

20 Thompson, Jacques Androuet Du Cerceau, 25-30, and Les plus excellents bastiments, 8,311

$2 \mathrm{I}$ Thompson, Les plus excellents bastiments, 313, Bibliothèque Nationale, Cabinet d'Hozier, no. 9, f. 2081.

22 The first drawings attributed to Du Cerceau were acquired by Phyllis Lambert in 1974. These are 17 folios of pen and ink drawings containing details of the orders executed by a member of Du Cerceau's workshop between 1545 and 1550 (Department of Prints and Drawings, DR 1974:0001:001-016. The drawings in the CCA measure approximately $36.8 \times 27.4 \mathrm{~cm}$. Provenance: Paris, Laget, Catalogue, Supplement [1971-72], no. 2748; New York, Lucien Goldschmidt, Catalogue 41 [1972], no. 128, to CCA, 1974. See Architecture and Its Image, nos. 113.1-3, 307, folios 4, 8, 17). The watermarks, a cross held by a bird (Briquet, no. 1255, used in Troyes 1532-39) are identical to those found in a series of 17 folios with drawings of similar subject matter in the Réserve of the Cabinet des estampes of the Bibliothèque Nationale, Ed. $2 r+$, Geymüller, Les Du Cerceau, 105, 109, part of Recueil C, $24.2 \times 34.5 \mathrm{~cm}$. After the Canadian Centre for Architecture was founded in 1979, the Prints and Drawings Department added to its collection in 1986 a model book (DR 1986:0108:001-081) consisting of 81 folios of pen and ink drawings on vellum on which designs of the orders, fountains, temples, churches, and palace façades were drawn. These drawings, measuring approximately $21.8 \times 31.2 \mathrm{~cm}$ each, were probably executed by members of Du Cerceau's workshop sometime after 1561, the date of the first edition of the Second livre d'architecture. 
volume in particular merits study. It contains two suites of engravings executed by the workshop, known as Temples et habitations fortifiés and Détails d'ordres d'architecture, grand format. The two suites of engravings reveal the close relationship between drawn and printed model books during the Renaissance, Du Cerceau's knowledge of ancient Roman and contemporary Italian architecture, and the actual use of these model books by patrons, architects, and master masons in sixteenth-century France. In addition to the two suites of engravings by Du Cerceau, this volume contains the first edition of Sebastiano Serlio's Book v, On Churches, printed in Paris in 1547. The binding, covered in marbled paper and measuring 38.2 by 25.4 centimetres, was made either at the end of the nineteenth or at the beginning of the twentieth century. ${ }^{23}$ The pages of the three parts of the volume are all the same size, 37.2 by 24.2 centimetres, and thus appear to have been uniformly cut when they were placed into the binding. At the time that the three parts were bound together, someone placed numbers in brown ink in the upper right-hand corner of the folios of the two Du Cerceau suites to correspond to the printed numbering of the folios of Serlio's book. ${ }^{24}$

Provenance: Robert, Cardinal of Olmütz, by 1849; London, Rudolf Eisenman, by 1948; to Cambridge, Philip Hofer, by 1948; to Myron Hofer II, by 1952; on deposit at Harvard University, 1951-85; to Boston, Ars Libri, by 1985; to CCA, 1986. It is not possible to identify this model book with any of the recueils listed by Geymüller, Les $D u$ Cerceau, 105. See Architecture and Its Image, no. 114. 308, fol. 32. The first book by Du Cerceau acquired by Phyllis Lambert in 1978 was the first edition of Lecons de perspective positive (Paris, 1576). 'The Library's collection was enriched in 1988 by the first edition of Du Cerceau's Livre des édifices antiques romains of 1584 .

23 cc.A Library, 87-B9512. The paper of the flyleaf is also of the nineteenth and twentieth centuries and has a watermark: MBM. Provenance: Acquired in 1987 by the CCA Library from Ben Weinreb, Ltd., London. Earlier provenance is unknown.

24 All the folios that follow Serlio's book are numbered except for two, a blank sheet between the Serlio book and the beginning of the Temples et habitations fortifiés, and one sheet between folios 88 and 89 of the Détails d'ordres d'architecture, grand format. Folios 1 through 35 contain the Serlio Book unnumbered. Folios 36 through 85 contain the complete set of the Temples (not in the correct alphabetical order), and folios 86 to 114 contain the complete set of the Détails d'ordres. The paper on all three items is sixteenth-century. Folios 1-35 have the watermark PS (Briquet, no. 9606, used in Paris between 1547 and 1550 ). Folios 36-85 have on intermittent pages the watermark grapes (Briquet, nos. 12.991-13.220 used in Europe from 1420 to 1600 ). Folios 86 - 114 have the watermark the circle (Briquet, nos. 2913-2932, used in France and Italy from 1293 to 1596). According to Guillmard, Les maîtres, 12-13, the complete set of the Temples et habitations fortifiés contains 50 folios marked $\mathrm{A}(1-3), \mathrm{B}(1-2), \mathrm{C}(1-3), \mathrm{D}(1-3)$, $\mathrm{E}(1-3), \mathrm{F}(1-3), \mathrm{G}(1-3), \mathrm{H}(1-3), \mathrm{I}(1-3), \mathrm{K}(1-2), \mathrm{L}(1-2), \mathrm{M}(1-$ 2), $N(1-3), O(1-2), P(1-4), Q(1-3), R(1-3)$ and that of the
It is not possible to determine whether these three parts were bound together in the sixteenth century. The folios of Serlio's Book v contain no hand-written inscriptions, whereas those of the two Du Cerceau suites do contain sixteenthcentury inscriptions written in ink. Those on the folios of the Temples are for the most part uniform, whereas those on the folios of the Détails d'ordres were made by three different hands. Various owners of these engravings tried to name the illustrations, since the two suites contain no text.

The most interesting inscriptions are found on the verso of the last folio of the Détails d'ordres. Four owners of this part of the volume signed their names (Fig. 131). The first also drew his self-portrait. The inscriptions read as follows:

A Jehan Fegueulx maçon et sculpteur suys et non a austre qui me trouvera/ cy me rende/ Jehan Fegueulx [self-portrait]/ Et depuis a Fleury [flourish] 1611 Fleury [flourish] tailleur de pierre [flourish] [illegible] ${ }^{25}$

The first and last signatures cannot be identified ${ }^{26}$ However, the second and third owners of this model book are well known. The third owner was Denis Fleury, a master mason and sculptor who lived on the rue des Lions and the rue NeuveSaint-Paul in Paris. We know through documents that he was responsible for the construction of the masonry of several important buildings built in and around Paris between 1566 and 1617. Among these are the Refectory, Guest-house, and church of the Chartreuse de Gaillon (1575); the Château de Wideville near Saint-Germain-en-Laye (1580); and the Hôtel de Claude de l'Aubespine on the rue des Bourdonnais in Paris (1585). ${ }^{27}$ The second owner who signed his name Fleury, with only the date of 1611 after it, was René Fleury. During the reigns of Henri IV and Louis XIII, René Fleury had the titles of "maitre général des oeuvres de maçonnerie du roi" and "conseiller du roi." An illustrious architect, René Fleury was active during the first half of the seventeenth century. Much new information about his career is soon to be published by Hillary Ballon. ${ }^{28}$

Détails d'ordres, grand format contains 30 folios unmarked See also Geymüller, Les Du Cerceau, 308, 314; Linzeler, Bibliothèque Nationale, Ed. 2c, 57, for the Temples; Ed. 2d, 59, for the Détails d'ordres.

25 I would like to thank Hillary Ballon for help in deciphering these inscriptions.

26 The last signature might read as Quiennhcar, but no masons or architects were found with a similar name in the card catalogue of masons at the Minutier Centrale of the Archives Nationales in Paris. No names were found similar to Fegueulx.

27 Catherine Grodecki, Documents du Minutier Centrale des notaires de Paris, 1500-1600, I (Paris, 1985), 51-52; II (Paris, 1986), 98

28 The publication of Hillary Ballon's dissertation, The Places 
The cca's engraved model book is not unique. The Musée du Louvre owns a model book of 49 drawings on vellum in which several signatures of its owner Charles du Ry are inscribed. Those found on the fly page are as follows:

Je suis à du Ry. ce présent livre appartient à Charles du Ry, architecte des bastiments du Roy travaillant pour Madame la duchesse de I ongueville à son Chasteau de Coulommiers, l'année que ledit Chastcau a esté commencé l'an 1613.

Charles du Ry, who executed some of the drawings in the model book, was a master mason. He was a relative of Salomon de Brosse, the architect of the Château de Coulommiers. It is quite possible, according to Rosalys Coope, that the Louvre's model book was given to Charles du Ry by Salomon de Brosse, who was a grandson of Jacques Androuet Du Cerceau. This model book contains several drawings of the Château de Verneuil and the Hôtel de Soissons, buildings associated with the Du Cerceau and de Brosse families. ${ }^{29}$ It has been suggested that model books executed on vellum were more often commissioned by wealthy patrons, whereas those drawn or printed on paper would have been commissioned by architects and masons. The example of the Louvre model book would refute this idea. The choice of vellum or paper, drawings or engravings, must have depended on how much money the person who commissioned the model book wanted to spend and not on that person's profession.

It is not possible to date either the Détails d'ordres or the Temples et habitations fortifiés securely since there are no known copies of these suites with a title page and date of publication. A hypothesis about the date of the Temples et habitations fortifiés will be proposed later. 'The Détails d'ordres appears to be a variant of a suite of 20 engravings known as the Détails d'ordres d'architecture, petit format which

Royales of Henry IV and the Urban Development of Paris 1600-1614 (Massachusetts Institute of Technology, 1984) by the Architectural History Foundation in New York will bring forward much new information ahout René Flcury. Those documents pertaining to Renć Fleury listed in the card catalogue of the Minutier Centrale of the Archives Nationales, but unpublished, are: cxxı 1569, cv 306, xIx 363, cV 307, LIV 480, cv 335, cV 342, xxix 174, cV 582, cV 381 , cv 384, c 387,1118

29 See Gencviève Monnier, Dessins d'architecture $d u x v^{\prime \prime}$ an XIX" siècle dans les Collections du Musée du Louvre (Paris, Cabinct des dessins, 20 March-2 June 1972), no. 22, RF 5946, 17-18, and Rosalys Coope, Salomon de Brosse (1.ondon, 1972), 219-20, 251-52, 274-77. Verneuil was partly constructed by Jean de Brosse, the son-in-law of Jacques Andronet Du Cerceau, beginning in 1568, and Salomon de Brosse, his son, between 1600 and 1617 , and the Hotel de Soissons was constructed by Jacques Androuet Du Cerceau, the Younger, between 1609 and 1622. See Thompson, Les plus excellents bastiments, 118-39, 314. also does not have a title page or date of publication. ${ }^{30}$ The Temples et habitations fortifiés is divided into two parts. Projects A to K seem to be temples or churches, and Projects $\mathrm{L}$ to $\mathrm{R}$ are most likely dwellings. This division must remain provisional since the inscriptions on the projects are not engraved and do not specify building type. The combination of temples, churches, and dwellings in one model book was not unusual in the Renaissance. It occurs in earlier Italian model books such as the two by Giuliano da Sangallo, one in the Vatican Library called the Barberini Codex, executed between 1485 and 1516, and the almost contemporary manuscript in the Bibliotheca Communale in Siena called the Siena Codex. In Book III, On Antiquity, Serlio illustrated villas such as that of Poggio Reale in Naples along with temples and ecclesiastical buildings like the Pantheon and the church of St. Peter's. ${ }^{31}$

The part of the suite devoted to temples is similar in subject matter to the suite of engravings of Christian churches and Roman temples known as the Moyens Temples, which was published with a Latin title page in Orléans in $1549 .{ }^{32}$ However, we cannot be sure that the Temples et habitations fortifiés was printed or designed at the same time as the Moyens temples, since Du Cerceau had prototypes of drawings which the workshop adapted in different printed and drawn versions. For instance, a drawing on vellum in the Bibliothèque Nationale by a member of Du Cerceau's workshop of a round, domed temple surrounded by a peristyle (Fig. 132), with the inscription "Temple de Jupiter," is actually a variant of Bramante's church of San Pietro in Montorio in Rome, which was illustrated in the engraved suite, the Moyens Temples (Fig. 133). ${ }^{33}$ While the engraving in the Moyens

30 The suite of engravings called Détails d'ordres, petit format, in the Bibliothèque Nationale, has a title page handwritten by the architect Callet listing Orléans as the place of publication and the date as 1549, which cannot be taken as evidence. See Linzeler, Bibliothèque Nationale, Ed. 2d, j9; Geymüller, Les Du Cerceau, 314; and Guillmard, Les maittres, 13. The engravings measure between 1.89 and $2.12 \mathrm{~cm}$ in height and 1.38 and $1.51 \mathrm{~cm}$ in width.

31 Scrlio, Book III, On Antiquity (Venice, Francesco Marcolini (la Forli, 1540; CCA Library, X0006181), folios CLI, VII-xviI, and xxxvII-xL. See also Christian Iluelsen, Il libro di Giuliano da Sangallo, Codice Vaticano Barberiano I.atino 4424, 1, notes, II, facsimile, 2nd ed. (Vatican, 1984). R. Falb, Il Tacuino (S.IV.7) senese di Giuliano da Sangallo (Siena, 1902). Sec folio xvin of the Siena Codex for the plans of the Pantheon and of a palace for Ferdinand of Aragon in Naples, and folio 8 recto of the Barberini codex for the lomb of Romulus and folio 8 verso for the same plan of the Palace for Ferdinand of Naples.

32 See note 12 and Linzeler, Bibliothèque Nationale. Ed. 2c. 56-57.

33 For the Temple de Jupiter, Bibliothèque Nationale, Réserve du cabinct des estampes, l.d. 2r, folio 3 verso, and 
Temples was copied from a woodcut illustration in Serlio's Libro terzo ${ }^{34}$ the drawing in the Bibliothèque Nationale was derived from the drawing of Bramante's church by Bernardo della Volpaia in a model book known as the Coner Codex, executed in Rome between 1513 and 1515.35 The church of San Pietro in Montorio and its variant, the Temple of Jupiter, both reappear in three other model books on vellum executed by the $\mathrm{Du}$ Cerceau workshop found in the Escorial, the Musée des Arts Décoratifs in Paris, and the Biblioteca Palatina in Parma. ${ }^{36}$

To understand what was meant by a model book in the sixteenth century and how architects, designers, masons, and patrons used these model books, it is necessary to investigate the sources of Du Cerceau's Temples et habitations fortifiés and Détails d'ordres d'architecture. There is an obvious connection between Du Cerceau's publications and the model book and manual composed by the Picard architect Villard de Honnecourt during the first half of the thirteenth century. Villard de Honnecourt's vellum manuscript, the only medieval model book by a French architect that has come down to us, contains drawings of plans and elevations of buildings and building parts, geometric diagrams, machines, and weapons. ${ }^{37}$ Until now, however, no attempt has been made to consider how Du Cerceau's books and suites of engravings are related to the development of Italian model books in manuscript form in the first half of the sixteenth century. Too much consideration has been given to Du Cerceau's dependence on Serlio's published manuals on architecture. Du Cerceau, of course, must have known Serlio, as David Thompson has suggested, since they both had the

Geymüller, Les Du Cerceau, 108, 109, 110, Recucil D. For San Pietro in Montorio, see folio 5 recto of Moyens Temples, Bibliothèque Nationale, Cabinet des estampes, Ed. 2c.

34 Serlio, Book III (Venice, 1540), folio xumir.

35 T. Ashby, "Sixteenth-Century Drawings Attributed to Andreas Coner," Papers of the British School at Rome, II (1904), 29, folio 33, and for the attribution, see Tilmann Buddenseig, "Bernardo della Volpaia und Giovanni Francesco da Sangello," Römisches Jahrbuch für Kunstgeschichte, xv (1975), 89-107.

36 Escorial, 28.Ir.5, folios 3 verso and 17 recto; Paris, Musée des arts décoratifs, CD 2698, folio 11 verso, folio 16 recto; Parma, Biblioteca Palatina, ms. 1208, folio 3 verso, folio 4 recto.

37 Paris, Bibliothèque Nationale, ms. fr. 19093. Roland Bechmann, in "Villard de Honnecourt: A Medieval Leonard," Apollo, cxxix, no. 326 (April 1989), 232-41, noted that since Villard called his notebook a "livre" and included page numbers on the folios and short texts written in Picard dialect, his manuscript should be considered more than just a model book. See also the latest facsimile edition. Régine Pernoud, Alain Erlande Brandenbourg, Jean Gimpel, and Roland Bechmann, Carnets de Villard de Honnecourt, XIII ${ }^{e}$ siècle (Paris, 1986). same patroness, Marguerite de Navarre. ${ }^{38}$ The evidence of the Temples and Détails d'ordres reveals that Du Cerceau's understanding of ancient Roman and modern Italian architecture was based not only on Serlio's published books but also on a knowledge of Italian sixteenth-century drawings, some of which may have belonged to Serlio and some of which Du Cerceau himself may have owned. ${ }^{39}$

From the third quarter of the fifteenth century well into the second half of the sixteenth century, architects and artists in Italy made studies of Roman buildings and their ornament in order to learn the principles of architecture. It was through the study of these monuments that new methods of depicting three-dimensional space were developed. Architects executed their drawings on individual sheets of paper and sometimes bound them together to make model books in which they kept repertories of the details of the orders as well as of important modern and ancient buildings. Sometimes these collections of drawings were also gathered together by patrons. ${ }^{40}$ Enlightened patrons consulted the drawings, while architects used them as a source of inspiration when designing modern buildings. Before the invention of printing, these individual drawings and sets of drawings had to be copied by hand since they were circulated among architects and patrons. ${ }^{41}$ Jacques Androuet Du Cerceau's two suites, Détails d'ordres d'architecture and Temples et habitations fortifiés, are printed versions of these Italian drawn model books. Du Cerceau achieved for the archi-

38 See notc 16

39 Thompson, Jacques Androuet Du Cerceau, 120-22. Because of this, he called Du Cerceau on 130 and 131 a "vulgarisateur" with a "lack of a profound knowledge of architecture." I do not necessarily agree

40 See John Shearman, "Raphael, Rome, and the Codex Escurialensis," Master Drawings, xv, no. 2 (1977), 107-10, 130-31. This Codex belonged to Don Rodrigo de Mendoza, a builder of a Calahorra Castle near Grenada, who was in Rome from 1506 to 1508. From Mendoza's collection it entered the Library of the Escorial in 1576 (Codex $28,11,12$ ). The Codex, executed by a member of Ghirlandiao's workshop in Florence, was probably brought from Florence to Rome by Giulia no da Sangallo, who gave it to Don Rodrigo.

41 These model books will be the subject of an exhibition at the cCA, From Sketchbook to Model Book and Treatise: The Renaissance Architect and Classical Antiquity 1450-1550. The literature on this subject is voluminous. The most recent contributions are the following: Arnold Nesselrath, "Raphael's Archaeological Method," Raffaello a Roma, Il convegno del 1983 (Rome, Bibliotheca Hertziana, Musei Vaticani, 1986), 357-71, pls. CXLII-CI.II, "I libri di disegni di antichità: tentativo di una Tipologia," Memoria dell'antico nell'arte italiana, ed. Salvatore Settis (Turin, 1986), III, 89-1 19, and Hubertus Günther, Das Studium der Antiken Architecktur in den Zeichnungen der Hochrenaissance (Tübingen, 1988). 
tectural drawing what the printed book had accomplished for literary texts. These printed model books could now be distributed more easily to a mass audience.

If we consider both the Détails d'ordres d'architecture and the Temples et habitations fortifiés in relationship to Italian sixteenth-century drawn model books, four main examples come to mind: the so-called Mellon Codex in the Morgan Library, executed between 1513 and 1520 by several artists; ${ }^{42}$ the Coner Codex in Sir John Soane's Museum; and the Vatican and Siena Codices by Giuliano da Sangallo, referred to above. ${ }^{43}$ These model books contain studies of details of the orders, plans, elevations, and perspective views of interiors anci exteriors of contemporary Italian churches and domestic buildings as well as of Roman temples, palaces, triumphal arches, baths, and tombs. ${ }^{44}$

The cCA's collection also contains a fragment of a drawn model book that may have originally been similar in content to the Barberini, Siena, Mellon, and Coner Codices. This model book can be closely related to Du Cerceau's Détails d'ordres d'architecture and Temples et habitations fortifiés. It was executed between 1520 and 1530 by an anonymous Italian artist and contains pen and ink drawings on 33 folios of Italian sixteenth-century paper. ${ }^{45}$ A large selection of Roman monuments

42 This manuscript has an inscription on the verso of the front cover / Anibale Fontannabonien / civis Bon / faciebat / M.1). XiII/. The sketchbook has been attributed to Domenico Antonio de Chiarellis, called Menicantonio, Domenico da Varignana, and an anonymous Venetian artist. See H. Naclod. "A Recently Discovered Architectural Sketchbook," Rare Books, vil, no. I (1955). 1-11; Christoph Frommel, Der Römische Palastbau der Hoch Renaissance (T'übingen, 1973), II, 16; and Sebastian Stor\%, in Raffaello architetto, ed. C. I. Frommel, S. Ray, and M. Tafuri (Milan, 1984), no. 3.2.12, 422-23. Sebastian Storz is preparing the facsimile edition. The manuscript was donated to the Morgan Library by Paul Mellon. See H. P. Kraus, Catalogue 75 New York, 1955), no.33, and The Paul Mellon (ifit to the Pierpont Morgan Library (New York, 1981), 27-28.

43 See notes 31 and 35 .

44 Monuments such as the Pantheon, the Colosseum, the Baths of Titus, the Basilica Aemilia, Bramantc's project for St. Peter's, the Palazzo della Cancelleria, and the Belvedere Courtyard of the Vatican Palace occur in the four codices. See notes 31,35 , and 42

45 CCA, Department of Prints and Drawings, DR 1982:002(): 0)1-033. Each drawing measures $32.5 \times 22.8 \mathrm{~cm}$. Provenance: London, Ben Weinreb Ltd.; to the CCA in 1982; by 1965 with H. P. Kraus, New York. See Catalogue 200 (1965), no. 200, 78. In this catalogue, the same English provenance is given for the cCA's and the Mellon's sketchbook. For the watcrmarks of the cCA's model book, see Briquet, three flowers in a circle surrounded by a star, nos. 6683-84, in use in Fabriano and in Rome, 1543-70. First published by James S. Ackerman, "The Tuscan/ Rustic Order: A Study in the Metaphorical Language of is illustrated in the cCA's Italian model book. Among these are the Temple of the Sibyl in Tivoli; the Temple of Fortuna Virilis near the Forum Boarium; the substructure of the Temple of Claudius on the slope of the Caelian Hill; the Carcer Mamertinus, the Roman State Prison at the foot of the Capitoline Hill; the Temple of Fortuna at Palestrina; the Mausoleum of Constantina, later the church of Santa Costanza; the Temple of Apollo at Largo d'Averno; the Garden Pavilion in the Licinian Gardens; the Maritime Theatre of the Villa of Hadrian at Tivoli; the Basilica of Maxentius; and details of the orders from various Roman buildings. ${ }^{46}$ John Bury discovered that all but 11 drawings in the CcA's model book are identical to sketches of ancient and modern buildings on the recto and verso of a sheet in the Uffizi (A 689) formerly attributed to Sallustio Peruzzi. Thus both the anonymous artist of the Uffizi sheet and the unknown draughtsman of the CCA's model book must have copied their drawings from similar prototypes. ${ }^{47}$

When we compare an engraved detail of the cornice of the Temple of Concord from Du Cerceau's Détails d'ordres, grand format (Fig. 134) to a drawing of two cornices in the ccA's Italian model book (Fig. 135), it is obvious that Du Cerceau must have used such Italian model books as a source. ${ }^{48}$ That the workshop of Du Cerceau produced both drawn and engraved versions of the same design is clearly shown by comparing the aforementioned engraved cornice (Fig. 134) to a drawing of an

Architecture," Journal of the Society of Architectural Historians, XI.II, no. I (March 1983), 23-24, fig. 10, folio 4 recto, fig. 12, folio 1 recto, and Phyllis Lambert, Centre Canadian d'Architecture/Canadian Centre for Architecture, Les débuts, The First Five Years (Montreal, 1988), no. 3, folio 4 recto, 38, and Architecture and Its Image, nos. 34.1-34.4, 200, ill. 201 , folios 17 recto, 15 recto, 15 verso, 1 recto, 2 verso. It is dated between 1520 and 1530 since the drawings are similar in style to those in both the Coner and Mellon Codices. In one case, folio 23 recto, the illustration of the garden pavilion in the Licinian garden, our anonymous artist copied the illustration on folio 15 of the Concr Codex (1513-15). Folio 32 recto depends on a drawing by Antonio da Sangallo, the Younger, of the Choir of St Peter's (Uf fizi A 45) executed between 1514 and 1521 . Sce Christof Thoenes, Die Frühen St-Peter-Entwürfe, 1505. 1514 (Tübingen, 1987), 116-17, figs. 110,106

46 Folios 13 recto, 13 verso, 14 recto, 15 recto, 15 verso, 17 recto, 4 recto, 1 verso, 2 recto, 3 recto, 19 recto, 21 recto, 22 recto, 25 recto, 29 recto, 5 recto, 6 recto, 7 recto, 8 recto, 9 recto, 10 recto, 11 recto, 12 recto, respectively. This manuscript will be studied in detail in the aforementioned exhibition on Renaissance model books.

47 John Bury, unpublished report, 1982, CCA, Department of Prints and Drawings, object file; for Uffizi A 689 recto and verso, see Alfonso Bartoli, I monumenti antichi di Roma (Rome, 1919), IV, pl. ccclxxiv, fig. 654.

$48 \mathrm{~J}$. B. Ward-Perkins, Roman Imperial Architecture, 2nd ed. (Harmondsworth, England, 1985), 39, fig. 16, 40. The temple was rebuilt by Tiberius, dedicated $10 \mathrm{AD}$. 
almost identical cornice in the cCA's collection (Fig. 136). This drawing is from a group of 17 folios of drawings on paper of details of the orders attributed to a member of Du Cerceau's workshop. The drawing of the cornice of the Temple of Concord does not appear to have been executed in preparation for the engraving, nor does it appear to have been exccuted after it. Both must have been derived from a common prototype. ${ }^{49}$

A comparison of the buildings in the ccA's Italian model book and several of the temples in $\mathrm{Du}$ Cerceau's Temples et habitations fortifiés reveals clearly that Du Cerceau had gained a knowledge of Roman architecture by copying similar drawings. Nine of the 11 temples in the Du Cerceau model book are identical to plans of buildings in the CcA's Italian model book. While Du Cerceau illustratcd both the interiors and exteriors of these buildings, no interior views have survived in the CCA's Italian model book. Ten of the 11 temples in Du Cerceau's model book are based on a circular plan and are crowned by a dome, in accord with the preference found in the writings of Alberti, Serlio, and Palladio for plans of religious buildings based on the circle. ${ }^{50}$

Du Cerceau's Project K, a round temple crowned by a central dome (Fig. 137), is identical to a drawing of a chamber from a Roman villa near Palestrina in the ccis's Italian model book (Fig. 138). ${ }^{51}$ The combined view of the interior and exterior of Project K (Fig. 139) gives us an understanding of the conventions Du Cerceau used to represent three-dimensional space. Du Cerceau cut away the wall to show half of a perspective section of the interior of the temple, in the same manner as the anonymous Italian draughtsman in the representation of Bramante's church of San Pietro in Montorio in the Gabinetto Nazionale delle Stampe, exccuted towards 1520, or Giuliano di Sangallo in his drawing of the so-called Temple of Portumnus at Ostia Antica in the Barberini Sketchbook; or even Serlio in some of the illustrations in Book III, On Antiquily, Book Iv, On the Orders, and Book v, On Temples. The viewpoint is very high in Du Cerceau's combined interior and

49 Sec note 22, cen DR1974:012.

$50 \mathrm{R}$. Wiltkower, Architectural Principles in the Age of $\mathrm{Hu}$ manism (New York, 1965), 3-27. Compare Du Cerceau, Temples et habitations fortifiés, $\mathrm{t}(\mathrm{)}$ the cCA's Italian model book: folios 72 verso to 29 recto, 75 verso to 28 recto, 80 recto to 30 recto, 83 recto to 24 recto, 63 verso to 19 recto, 66 recto to 22 recto, 69 recto (o) 26 recto, 48 verso to 31 recto, 77 verso to 20 recto, 51 verso to 18 recto.

51 Folio) 18 recto of the cca's Italian model book has an inscription: "a Palcstrina di matoni arodati." See Luigi Crema, L'architettura romana (Turin, 1959), fig. 806, 607; 608,609 . Crema dates the Roman structure at the end of the third century AD. exterior view (Fig. 139)..$^{52}$ There are no crosssections drawn in orthogonal projection in the Temples el habitations fortifiés as there are in several rare drawings in the Codex Coner..$^{53}$ Likcwise, Du Cerceau does not always draw true elevations in orthogonal projection, since he often incorporates elements drawn in perspective in the same way as Bernardo della Volpaia in the Coner Codex; Giuliano da Sangallo in the Barberini Codex; and Serlio in Books III, IV, and v. ${ }^{54}$ Du Cerceau's avoidance of the orthogonal projection in the Temples et habitations fortifiés ties him very closcly to the draughtsmen of the aforementioned model books. His preference for the perspective section and high viewpoint in the Temples et habitations fortifiés reveals that he did not choose to follow the principles of orthographic projection Raphael elaborated in his letter of 1515 to Pope Leo x. Nor does Du Cerceau seem to have been closely influenced by those drawings of Antonio da Sangallo, the Younger, or Serlio in which elevations and cross-sections are shown in orthogonal projection. Antonio da Sangallo, the Younger, had used this method of projection in his drawings by $1520 .^{55}$ Serlio first consistently drew elevations and crosssections in orthographic projection in the two preparatory manuscripts for Book vi, On Domestic Architeclure, executed in France between 1541 and

52 Rome, Gabinetto Nazionale delle Stampe, 2510, folio 5 verso. Sce Günther, Das Studium, pl. 76a, 350-53, 375, and A. Nesselrath, no. 3.5.8, 440, in Raffaello architetto. For the Barberini Codex, folio 37 recto, inscribed "Tempidi Porto di la da (ostio," sec Iluelsen, Il libro, 1, 54. Scrlio, Book III (Venice, 1540), folio xxvir, Temple of the Sybil at Tivoli, XL, Dorne of St. Petcr's, Book v (P'aris, 1547), project I, folio 1 verso, project 2, folio 6 verso.

53 Sce Ashby, "Sixtecnth-(Century I)rawings," Codex Coner, folio 20, Mausoleum of Constantia, folio 38. Pantheon, folios 39, 40, Colosscum, and folio 46, Belvedere Courtyard. When Du Cicrceau does depict cross-scctions as in that of Castle K, they are not true cross-sections drawn in orthographic projection since elements of the exterior, such as the roof and dormer windows, are included, and the arches of the courtyard are shown in perspective.

54 See Ashby, "Sixteenth-Century Drawings," Coclex Coner, folio 34, Tempietto, folios 35-36, Pantheon, and Barberini Codex, folio 4 recto, Theatre of Marcellus, folio 5 verso, Markets of Trajan, folio 12 verso, Colosseum, in Huelsen, Il libro, II. Sec Scrlio, Book m (Venice, 1540), folios xi.ıx, Theatre of Marcellus, I.VI, Markets of Trajan, t.xxv-txxix, Colosseum, I.xxxvi, Bridges on Tiber, $c v$, Arch of Titus, Book Iv (Venicc, 1540), folios vi, vili, Tuscan Arches, xxxır, Doric Palace Façade, Bookv (Paris, 1547), project 6, folio 15. Scc in Du Cerccau, Temples, folios 73 verso $(\Lambda), 56$ recto $(M), 59$ recto $(N), 43$ recto (Q), 44 recto $(Q)$, for elevations of façades drawn in orthogonal projection.

55 Wolligang Lotz, "The Rendering of the Interior in Architectural Drawings of the Renaissance," Studies in Italian Renaissance Archilecture (Cambridgc, Mass., 1977), 1-66, and (Christof Thocnes, "La lettcra a Leone x," in Raffaello a Roma, 373-85. 
1550.56 Lotz and Thompson have noted that throughout his career, Du Cerceau showed a preference for the more pictorial methods of representing a building by perspective views or isometric projections. ${ }^{57}$

Like other Renaissance artists who studied classical antiquity, Du Cerceau often identified Roman tombs as temples. Project I (Fig. 140), a rather complex centralized structure with alternating round niches and pedimented aediculae in the interior, was based on a drawing of the Tomb of Romulus on the Via Appia in Rome (Fig. 141). This tomb was depicted not only by the anonymous artist of the CCA's Italian model book but also by Bernardo della Volpaia in the Coner Codex; by Giuliano da Sangallo in the Barberini Codex; by Baldazzare Peruzzi; by Sebastiano Serlio in Book III; and by Andrea Palladio. ${ }^{58}$ The depiction of the interior (Fig. 142) clearly reveals Du Cerceau's preference for the perspective section and his dependence on similar types of sections found in the Coner Codex and in Serlio's Books III and v. ${ }^{59}$ Du Cerceau's view of the interior of this temple, like the others in the suite, is too schematic to convey the spatial complexity projected in the ground plan.

An example of Du Cerceau's creative interpretation of classical antiquity is found in Project D (Fig. 143). The plan of this temple is based on a plan of the Serapaeum of Hadrian's Villa at Tivoli as it was depicted in the CCA's Italian model book (Fig. 144) ${ }^{60}$ However, Du Cerceau has changed this structure, transforming its half-dome into a full one and has added a modern Italian façade with a Serlian motif derived from his perusal of Serlio's Books Iv and v (Fig. 145) ${ }^{61}$ The addition

56 Rosenfeld, Sebastiano Serlio, 29-30, and Marco Rosci, Il Trattato di architettura di Sebastiano Serlio (Milan, 1967), 14.

57 Lotz, "The Rendering of the Interior," 32, and Thompson, Les plvs excellents bastiments, 14-18.

58 Ashiby, "Sixteenth-Century Drawings," Codex Coner, folio 6, Barberini Codex, folio 43 verso, in Huelsen, Il libro, II, and I, 59, Peruzzi, Uffizi A $111 \mathrm{r}$ in Heinrich Würm, Baldussare Peruzzi, Architekturzeichnungen, Tafelband (Tübingen, 1984), pl. 484, Sebastiano Serlio, Book III, folio, XLV and Andrea Palladio, RIBA, viII/7, in Heinz Spielmann, Andrea Palladio und die Antike (Munich, 1964), no. 7, 19, 137, fig. 4. See also Palladio, I Quattro Libri (Venice, 1570), folio 89. See Crema, L'architettura romana, $625-28$, fig. 829,625 , who dates this structure after $309 \mathrm{AD}$.

59 See note 57. Du Cerceau copied Serlio's perspectival section of the Pantheon from Book III, folio Ix, in folio 1 of the Moyens Temples. See Linzeler, Bibliothèque Nationale, Ed. 2c, 56. See also Serlio, Book v (Paris, 1547), project 3, folio 8 verso, project 5 , folio 16 recto.

60 Salvatore Aurigemma, Villa Adriana (Rome, 1984), 100-33, fig. 84, 105, and Ward-Perkins, Roman Imperial Architecture, 109-10, fig. 50, 109, dated after $130 \mathrm{AD}$.

61 This project was transformed into two designs for manors in the Troisième liure (Paris, 1582), projects I and viI. See of extra parts to this Roman building, common in the Renaissance, was the result of a lack of exact knowledge of its original configuration. Du Cerceau's interest in these Roman monuments was shared by his contemporaries in Italy. The temple illustrated in Project G (Fig. 146) was based on a drawing of the Cenotaph of Antonius, which was located near the Porta Maggiore in Rome (Fig. 147). ${ }^{62}$ It is extremely significant that Antonio da Sangallo, the Younger, used the same tomb as the basis for the plan of his church of the Madonna di Monte d'Oro near Montefascione, constructed between 1523 and $1548 .^{63}$ This close relationship between Roman tomb and Christian church epitomizes as well the Renaissance programme for the ideal church. ${ }^{64}$

Several other sixteenth-century Roman churches were used as sources of inspiration for some of the temples in Du Cerceau's Temples et habitations fortifiés. Project B (Fig. 148) was based on a drawing of Bramante's church of SS. Celso and Giuliano in Rome which was represented not only in the cCA's Italian model book (Fig. 149) but also in the Coner and Mellon Codices and in a drawing by Antonio da Sangallo, the Younger. ${ }^{65}$ Evidence of Du Cerceau's knowledge of the projects for the church of St. Peter's in Rome by Raphael and Antonio da Sangallo, the Younger, is illustrated by Project E. The complex plan (Fig. 150) was developed from a basic Greek Cross design. This plan, with its axial symmetry, angular exterior walls, and domes in the arms of the Greek Cross, appears to be a variant of the east end of a longitudinal project for St. Peter's in the Uffizi (A 254), which Antonio da Sangallo, the Younger, executed between 1518 and 1519 when he was assistant to Raphael, the capomaestro of the Fabbrica ${ }^{66}$ At this time, according to Christoph Frommel, Sangallo was still thinking of an alternative

Serlio, Book iv (Venice, 1540), folios xxxili-xxxıv, Doric Palace façades, Book v (Paris, 1547), façade of project 4, folio 10 verso

62 Ernest Nash, Pictorial Dictionary of Ancient Rome (London, 1968), II, 130, fig. 848, 132, on the Via Labicana, second century AD. Drawing by Sangallo, Uffizi (number unidentified by Nash).

63 Gustavo Giovannoni, Antonio da Sangallo il Giovane (Rome, 1959), I, 223-26, II, fig. 204 (Uffizi A 173). See also other drawings for this church, Uffizi A 1275 and A 947.

64 Wittkower, Architectural Principles, 25

65 Ashby, "Sixteenth-Century Drawings," Codex Coner, folios 18,19 . Mellon, folios 56 verso-57 recto. See also Ashby, 19, for mention of Uffizi A 875 by Antonio da Sangallo, the Younger.

66 Frommel, in Raffaello architetto, 267, ill., 248. See also Uffizi A 1368 by Sangallo, the Younger, for a similar type of centralized plan with oval chapels on diagonal axes, in Giovannoni, Antonio da Sangallo, II, fig. 10. Du Cerceau may have also been influenced by project 2 in Serlio's Book v (Paris, 1547), folio 5 verso. 
centralized plan for St. Peter's in the tradition of Bramante. In the right-hand margin of a second contemporary drawing in the Uffizi (A 252r), Sangallo made a sketch of a centralized plan for St. Peter's based on that of the Pantheon. ${ }^{67}$ The façade of Du Cerceau's Project E, with its triangular pediment above an attic and applied columns alternating with niches, is a variant of a third contemporary drawing in the Uffizi (A 73r) by Sangallo for the façade of St. Peter's. ${ }^{68}$

Peter Murray, Christoph Frommel, and Arnold Nesselrath have already noted that the façade of one of Raphael's projects for St. Peter's, represented in a drawing in the Mellon Codex, forms the basis for an engraving in Du Cerceau's Moyens Temples (Fig. 151). In contrast to the draughtsman of the Mellon Codex, who executed his drawing in 1518, Du Cerceau added two towers behind the church façade and simplified the decoration of the exterior. The workshop of Du Cerceau used the same design as a point of departure for other variants of St. Peter's which are called the Temple of Ceres in two manuscripts now in English collections. ${ }^{69}$ Peter Murray thought that in addition to the drawing in the Mellon Codex, Du Cerceau must have seen a wood model of St. Peter's because the towers at the back give Du Cerceau's engraved representation a three-dimensional quality. However, the addition of these towers may just as well have been an artistic convention. If Du Cerceau had seen a wood model by Antonio da Sangallo, the Younger, it would have had to have been the earlier one made in 1521 , since his façade bears little resemblance to that of the 1539 wood model now in St. Peters. ${ }^{70}$

67 Frommel, in Raffaello architetto, no. 2.15.11, 268, ill. 267. 68 Frommel, in Raffaello architetto, no. 2.15.28, 284, ill.

69 Frommel and Nesselrath, in Raffaello architetto, no. 2.15.14, Mellon Codex, folios 71 verso-72 recto, 270-71, ill., 271, Du Cerceau drawings and engraving, ill., 250. For the Moyens Temples, folio 24, see Linzeler, Bibliotheque Nationale, Ed. 2c, 56-57, and Peter Murray, "Menicantonio, Du Cerceau, and the Towers of St. Peter's," Studies in Renaissance and Baroque Art Presented to Anthony Blunt on His 60th Birthday (London, 1967), 7-12.

70) Murray, in "Menincantonio," 10, had compared folio 24 of the Moyens Temples to a drawing formerly in the Schloss Wolfegg (Thoencs, Die Frühen, fig. 28, 33) which shows one tower at the back. However, this drawing is much earlier and reproduces Bramante's façade for St. Peter's as shown in the foundation medal of Caradosso of 1506 , and it differs in detail from the Du Cerceau engraving which is closer to the Raphael project. I disagree with Murray that Du Cerceau based his engraving on Antonio da Sangallo, the Younger's, wood model for St. Peter's of 1539. Sangallo made an earlier wood model of St. Peter's in 1521 , but its exact configuration is unknown. Frommel suggested that the 1521 model is represented in some drawings by a contemporary French artist in the Staatsbibliothek in Munich (Codex Icon, 195). Sce Frommel, in Raffaello architetto, no. 2.15.44a-f, 299-300, ill., 301-302.
Project L (Fig. 152) begins the section devoted to dwellings in Du Cerceau's Temples et habitations fortifiés. Of the seven projects (L-R), the plans of five $(M, N, P, Q, R)$ are based on dwellings illustrated by Serlio in the two preparatory manuscripts for Book vi, On Domestic Architecture. ${ }^{71}$ According to Francesco Paolo Fiore, the plans of Projects $\mathrm{L}$ and $\mathrm{O}$ by Du Cerceau are based on a drawing by Francesco di Giorgio in the manuscript version of his treatise found in the Biblioteca Reale in Turin. ${ }^{72}$ In this section of the Temples et habitations fortifiés, Du Cerceau develops the theme of the Palace-Villa-Temple so eloquently formulated by Andrea Palladio in the archetypal monument of this genre, the Villa Rotonda. Palladio of course was preceded by other architects who experimented with this theme in the fifteenth and sixteenth centuries. ${ }^{73}$ These antecedents are clearly alluded to in the plan of Du Cerceau's Project L (Fig. 152) based on the plan of a building that Francesco di Giorgio identified in the Turin manuscript as the House of the Emperor Nerva in Rome. Three rectangular rooms, at right angles to one another, preceded by porticoes, lead to an inner courtyard and audience hall on the main central axis. On the exterior of the building, Francesco di Giorgio has placed segmental, curved porticoes. Du Cerceau's only change is the piers that have been added to the interior courtyard of Francesco di Giorgio's drawing. In the text of the Turin manuscript, Francesco di Giorgio clearly identified this building as a house:

in Roma dove se dice la chasa di cesari. Ma fu di Nerva et avia tre portichi de' quali in magior parte di tucti e tre si vede, hel quale hedificio la circumferentia he tucta di peperingnio-portico-portico-fondo-portico-portico.

In reality, Francesco di Giorgio was trying to represent the Temple in the Forum of Nerva whose façade appears above the plan in the Turin manuscript. ${ }^{74}$ In the view of the exterior of Project $L$

71 Compare the Du Cerceau to Serlio in Rosenfeld, Sebrastiano Serlio, folios 55 recto (M) to pl. LIV (P), folio 57 recto (N) to pl. $\mathrm{x}(\mathrm{R})$, folio 40 verso (P) to $\mathrm{pl}$ x xxi1 (25), folio 42 recto $(Q)$ to $\mathrm{pl}$. xxvin (22), and folio 45 recto $(\mathrm{R})$ to $\mathrm{pl}$. $x \times x$ (ET23).

72 Project $\mathrm{O}$ (folio 36 verso) is a variation of Project I.. Verbal conversation. Codex Saluzziano 148.

73 Rosenfeld, Sebastiano Serlio, 54, Project Y25, pls. xxxiI, xxxı11, Project 27, pls. xxxvi, xxxvi1, and Project 30, pl. xurv. See also Rosci, Il trattato, 76-77, and Wolfgang Lotz, "The Rotonda: A Secular Building with a Dome," in Studies, 190-96. The most important earlier prototype was Giuliano da Sangallo's Villa of Poggio a Cajano near Florence of 1485 which has a façade with a temple front.

74 Francesco di Giorgio Martini, Trattati di architettura, ingegneria e arte militare, ed. Corrado Maltese, transcribed by Livia Maltese Degrassi (Milan, 1967), I, 279, pl. 141, Codex Saluzziano, folio 77 recto. Maltese interpreted Francesco di Giorgio's text as relating to the Temple of 
(Fig. 153), Du Cerceau combines frontal and side elcvations of the building. The main façade, with its central Serlian motif, is derived from the façades of dwellings III and IV of Book viI, On Accidents, composed by Serlio at Fontaincbleau between 1542 and $1547 .{ }^{75} \mathrm{Du}$ Cerceau's palacevilla façade thus carries allusions to the Roman temple front. This method of combining a frontal elevation with a side elevation is used only rarely by Serlio but does occur often in earlier sixteenthcentury drawings, in particular in a drawing of a tabernacle in the Gabinetto Nazionale delle Stampe executed towards 1520 by an anonymous Italian artist. ${ }^{76}$ At first sight, the multiple temple fronts and conventions of representation used in the exterior view of Project L (Fig. 153) remind us of the illustration of the Villa Rotonda in Palladio's I Quattro Libri. ${ }^{77}$ Du Cerceau knew of Palladio's treatise, since a member of his workshop copied six villas from the Quattro Libri in a vellum manuscript, now in the Morgan Library, which was probably executed sometime during Du Cerceau's stay at Montargis between 1565 and $1581{ }^{78} \mathrm{How}$ ever, Du Cerceau does not combine a cross-section of the building in Project $\mathrm{L}$ with an elevation of the extericr as Palladio did in his illustration of the Villa Rotonda. This would have made the frontal and side elevations appear more plausible. The resulting spatial ambiguity of Du Cerceau's repre-

Nerva, but on another example on the verso of the same manuscript, folio 77 verso, Francesco di Giorgio used the word "tempio" to refer to the lemple of $\Lambda$ ntoninus and Faustina. Thercfore, I would assume that the word "chasa" on folio 77 recto is a reference to the Housc of the Caesars. Serlio in Book III (Venicc, 1540), folio Lxxx, identified Caracalla's Temple of Serapis (211-217 AD) on the Quirinal Hill as a palace "vestigi di un superbo Palažo." Sec: Ward-Perkins, Roman Imperial Architecture, 134. It is not possible to tell exactly how the façade of the temple in the Forum of Nerva on folio 77 recto relates to the plan. Du (erceau's project () (folio 36 verso) is based ont the same drawing by Francesco di Giorgio.

7.) Rosenfeld, Sebastiano Serlio, 22, and Serlio, Book VII, Sebastiani Serlii bononiensis liber septimus (Franklurt, 1575) folios 7 and 9

76 Gunther, Das Studium, G.N.S., 2510, folio 3 recto, pl. 74a, 339-49, Arnold Nesselrath, no. 3.4.8.440, in Raffaello architetto.

77 I (Quattro Libri (Venice, 1570), Book II, folio 19

78 Naomi Miller, "A Volumc of Architectural Drawings Ascribed to Jacques Androuet Du Cerceau, the Filder, in the Morgan Library. New York," Marsyas, xı (1962-64), 36, folio 103 verso, Villa Ihiene at Cigogna, folio 104 recto, Villa Mocenigio, 105 verso, Villa Emo at Fanzolo and the Villa Trissino at Meledo, 106 recto, Villa Polignana and the Villa $\Lambda$ rgarono. The 96 pages of the manuscript mcasure $32.5 \times 2.10 \mathrm{~cm}$. It was given by J. P. Morgan in 1927. Provenance: Sotheby's, London, 14 June 1926, no. 62; B. Ouaritch I.td., London, Catalogue no. 402 (1926), no. 3587. This manuscript will be inclucled in a new catalogue of French drawings in the Morgan I ibrary being prepared by Cara Denison :vith the assistance of Rurh Kraemer. sentation of the exterior of Project $\mathrm{L}$, in my opinion, indicates that he was not influenced by the illustration of the Villa Rotonda in Palladio's Quattro Libri but, rather, by an earlier sixteenthcentury drawing like the one of the tabernacle cited above. The additive quality of the design of Du Cerceau's palace façade makes it appear closer in conception to the façade of the fifteenthcentury Villa of Poggio a Cajano by Giuliano da Sangallo than to that of the Villa Rotonda. A variant of the engraved illustration of the extcrior of Project L (Fig. 153) was repeated by a member of Du Cerceau's workshop in an ink drawing that is part of a vellum model book in the CCA's collection (Fig. 154). ${ }^{79}$

The copies and variants Du Cerceau made in the Temples et habitations fortifiés of projects elaborated by Sebastiano Serlio in the earlier preparatory manuscript in the Avery Library for Book vi, On Domestic Archilecture, support David Thompson's thesis that Du Cerceau had a firsthand knowledge of the contents of Book vi even though it was never published. ${ }^{80}$ The plan of the pavilion in Project P (Fig. 155) is a variant of Serlio's original plan for the Grotte des Pins at Fontainebleau as illustrated in the Avery version of Book vi (Fig. 156). Serlio's project for the Grotte des Pins and a related house for King Francis $\mathrm{I}$ in the Avery manuscript are among the earliest secular buildings designed in the sixteenth century that have a centralized plan and are crowned by a dome. Both these designs had a certain influence on Palladio's design for the Villa Rotonda. ${ }^{81} \mathrm{Du}$ Cerceau did not slavishly copy Serlio. There are several changes in the plan, and the elevation of Du Cerceau's pavilion in Project $P$ (Fig. 157) retains only the rusticated basement of the exterior elevation of Serlio's design for the Grotte des Pins (Fig. 158). Du Cerceau has based the design for the upper floors of his pavilion on the above-mentioned drawing of a tabernacle exccuted by an anonymous Italian artist towards 1520, found in the Gabinetto Nazionale delle Stampe. ${ }^{82}$ Du Cerceau again adapted from this Italian drawing the convention of combining frontal and side elevations in one image.

Du Cerceau also took liberties with Serlio's designs in his elaboration of the series of fortified dwellings. The plan of Project R (Fig. 159) is based

79 See note 22

80 Ihompson, Jacques Androuet D) (erceau, 120-22, and Les plus excellents bastiments, 143-43, suggested that some of the projects Du Cerceau published in the Livre d'architecture in 1559 are derived from Book vi, for example Project Xvi, which is a version of Serlio's design for Ancy-lc-Franc.

81 See note 73

82 See note 76 
on Serlio's Castle for a Tyrant Prince in the Avery manuscript (Fig. 160). ${ }^{83}$ Du Cerceau eliminated the moat and fortified wall with triangular bastions that surround Serlio's castle and slightly changed the placement of the interior staircases. The elevation of the façade of Du Cerceau's Project R (Fig. 161) is completely different from Serlio's design. Du Cerceau's castle façade has little relationship to the plan. Instead of being built on a high basement with triangular bastions at the corners, this castle has round towers and appears to be an adaptation of Serlio's drawing of the façade of a pavilion for Francis I illustrated in the Avery manuscript for Book vi. Du Cerceau has incorporated into his own design its rusticated basement, round towers surmounted by conical roofs, and high dormer windows. ${ }^{84}$ The apparent carelessness with which the plan and clevation of Project R (Figs. 159 and 161) were placed one after the other supports Henry de (scymüller's attribution of the exccution of the suite of the Temples et habitations fortifiés to the workshop of Du Cerceau ${ }^{85}$ The workshop must have made up these model books rather hastily from the large repertory of drawings that belonged to Du Cerceau. The elevation of the façade of Project R (Fig. 161) reveals how perspective elements were incorporated into Du Cerceau's clevations. The thickness of the round towers is clearly indicated by the shadows created by a scries of parallel hatchings. A castle façade with round corner towers from Du Cerceau's engraved suite of 15 plates called Petites habitations ou Logis domestiques is very close in conception (Fig. 162).86

Thus, in conclusion, we have seen how Du Cerceau in the designs for the Iwo suites of engravings, Détails d'ordres d'architecture, grand format and Temples et habitations fortifiés, had access to a large selection of sixteenth-century Italian drawings. It is also apparent that he had a rather wide knowledge of ancient Roman and contemporary Italian architecture, from the Villa of Hadrian at Tivoli to the church of St. Peter's in Rome. Although it could be argucd that Du Cerceau knew these monuments only second-hand, through these Italian drawings, I am in agreement with Henry de Geymüller, Janet Byrne, and Francesco Paolo Fiore

8.3 Roscnleld, Sebastiano Serlio, pl. xxx (Project ET.23), 52-53.

84 Rosenfeld, Sebastiano Serlio, pl. xxxv (Project R 26). See also pl. xxxix (Project 28).

85 Geymüller, Les Du Cerceau, 308

86 Geymüller, Les Du Cerceau, 308, dated this suite between 154() and 1545. See Linzeler, Bibliolhique Nationale, Ed. 2c, 57-58. The set in the Cabinet des estampes has a title page handwritten by the architect (allet, with Orléans as a place of publication and a date of 155() , which cannot be used as evidence of date. See also (;uillmard, Les maîtres, 13. that Du Cerceau must have made a trip to Rome sometime in the 1530s, before he received protection from Francis $\mathrm{I}$ in $1545 .{ }^{87}$ It seems to me that Du Cerceau would not have been interested in these Italian drawings if he had not had first-hand contact with these Roman and Italian monuments.

A close relationship between Du Cerceau's designs and the earlier manuscript now in the Avery Library for Book vi, On Domestic Architecture, which Serlio executed at Fontainebleau between 1541 and 1547, indicates that Du Cerceau may have elaborated the designs for the suite Temples et habitations fortifiés during the early part of his career, between about 1545 and 1559 while he was living in Tours and Orléans. Many of the drawings that served as a source of inspiration for Du Cerceau are associated with designs for ecclesiastical buildings that Bramante, Raphael, and Antonio da Sangallo, the Younger, elaborated in Rome between 1510 and 1520. Du Cerceau may have acquired some of these drawings during his trip to Rome. Many of them may have also belonged to Serlio, since he was in Peruzzi's workshop in Rome from 1516 to 1528. Serlio himself reproduced both Bramante's and Raphael's projects for St. Peter's in Book III, On Antiquity. ${ }^{88}$ Serlio may even have given or sold some of these drawings, or copies of them, to Du Cerceau. Thompson has proposed that Du Cerceau may have added the French titles to some of the drawings in the Avery manuscript for Book vi. ${ }^{89}$ The possibility that Du Cerceau owned the Avery manuscript for Book VI, as well as other Italian drawings that may have belonged to Serlio, would disprove Jacopo Strada's statement in the preface to Book vil that he bought from Serlio in Lyons in 1550 all of his manuscripts as well as all the drawings by other artists that Serlio intended to publish during his lifetime. ${ }^{90}$ The fact that the Avery manuscript

87 Geymüller, Les Du Cerceau, 5-34, 106. Geymüller based his point of view on an album of drawings in the Staatsbibliothek in Munich (Recueil A. 106, Codex Icon 195) which has subsequently becn attributed to Phiibert I)clorme by Blunt and to Jean de (hencvières by Christoph lirommel, since it contains drawings of monuments in Rome such as Palazzo Branconio dell'A quila, the Palazzo Farnese and St . Peter's (see Frommel, no. 2.15.44a-f, 299-302, in Raffaello architetto). See also Janet Byrne, "Jacopo della Vave," 146-47, Paolo Fiore, "Palazzo e Tipologia Trionfale: Disegni inediti del Du Cerceau," Piscon, nos. 8-9 (1976), 112-23, on the basis of Codex Barberini Lat. 4398 in the Vatican Library, which is without doubt by 1) (erceau himself:

88 Rosenfeld, Sebastiano Serlio, 18, Serlio, Book III (Venice, 1540), folios xxxvil-xi.. See also Frommel, nos. 2.1.5.3-4, in Raffaello architetto, 259-60.

89. Thompson, Jacques Androuet Du Cerceau, 122, and Les ples excellents bastiments, 143. I do not think that the handwriting is Du Cerceau's.

90 Rosenfeld, Sebastiano Serlio, 26, Serlio, Book viI (Frankfurt, 1575), pl. 1.xv, lines 4-5. 
stayed in France until the beginning of the eighteenth century, the existence of the printer's proofs of Book vi in the Albertina (made in France at the end of the sixteenth and beginning of the seventeenth century), and the evidence of the dwellings based on designs by Serlio in the Temples et habitations fortifiés add support to Thompson's hypothesis that Du Cerceau may have owned the Avery manuscript for Book vi. ${ }^{91}$ Serlio's own contact with the Protestant milieu in Venice and France would have created personal links with Jacques Androuet Du Cerceau, as would the fact that they had common patrons in Marguerite de Navarre and the ruling family of the Duchy of Este. ${ }^{92}$ However, until more documentary evidence is discovered, we cannot know for certain whether Serlio gave these drawings to $\mathrm{Du}$ Cerceau in the hope that he would publish them for him, or whether Du Cerceau merely copied Serlio's projects and the drawings by others in his possession.

As much as the two artists may have been linked by a common milieu, there is an important difference between Serlio's publications and Du Cerceau's. Serlio's publications, except for the Extraordinary Book on Doors, are practical manuals, while Du Cerceau's are model books. Serlio accompanies his illustrations in Books I-VI with detailed texts in which he describes and analyzes his illustrations. These texts are found on either the same page as the illustration or the page opposite. In the Avery manuscript for Book vi, there are specifications as well as practical information on construction methods and in some cases, as in the illustrations of Town Houses $G$ and $P$, alternative solutions. ${ }^{93}$ In Du Cerceau's books, all the illustrations are placed at the end, with the descriptive texts grouped together at the beginning. Françoise Boudon has suggested that $\mathrm{Du}$ Cerceau's building designs were not meant to be built specifically as they were illustrated. They should rather be considered models that could be changed according to the desires of the patron, architect, or mason. ${ }^{94}$ In the texts, Du Cerceau does not analyze the buildings or explain to the reader how to actually construct them or even how to use the decorative motifs. The short commen-

91 Rosenfeld, Sebastiano Serlio, 27, ill. at end of text.

92 Rosenfeld, Sebastiano Serlio, 43-45, and Manfredo Tafuri, Venezia e il Rinascimento (Turin, 1985), 101-22.

93 Rosenfeld, Sebastiano Serlio, pls. xuIx (G), and LII-Lvi (P) and "Sebastiano Serlio's Contributions to the Creation of the Modern Illustrated Architectural Manual," Bulletino del Centro Internazionale di Studi di Architettura Andrea Palladio, xxxI (1989), 186-87.

94 Françoise Boudon, "Les livres d'architecture de Jacques Androuet Du Cerceau," Traités d'architecture de la Renaissance, ed. Jean Guillaume (Paris, 1988), 367-97. taries in Du Cerceau's books should be regarded more as descriptive titles for the illustrations than as analytical text. The only manual Du Cerceau produced was Leçons de perspective positive of 1576, which contains brief instructions on how to actually use principles of perspective. It is interesting that in one case, Sebastiano Serlio himself may have been influenced by Du Cerceau's suites of engravings and printed books. His Libro extraordinario, On Doors, published in Lyon in 1551, was unique in his oeuvre, since it was printed with engraved illustrations instead of woodcuts and was designed like Du Cerceau's books with all the illustrations at the end and short descriptive titles in letterpress at the beginning. ${ }^{95}$

The ccA's copy of the Détails d'ordres d'architecture, grand format is a precious document, since it provides us with concrete evidence of who owned and used Du Cerceau's model books. Denis Fleury, who owned this suite of engravings, signed a document on 10 February 1580, as "maistre maçon entrepreneur," with another Parisian mason, Guillaume Marchant, who was to guarantee his work, to build the Château de Wideville for Benoît Millon, Intendant des finances of King Henry III from 1573 to 1584 . The document indicates clearly that the building was to be constructed by Denis Fleury according to a drawing that Millon had someone else execute. Fleury was to execute the masonry "suyant le pourtrait et desseing qu'il [Benoît Millon] en a fait faire et icelluy monstré audit Fleury et à luy delaissé."96

Catherine Grodecki, who discovered this document, has suggested that Benoît Millon asked Jacques Androuet Du Cerceau to execute the drawing for the Château de Wideville, since the castle is identical in plan to Project XxII of the third Livre d'architecture, published in 1582, and is also very similar in elevation to a drawing executed by Du Cerceau himself of the exterior of a castle in the vellum model book now in the Morgan Library, which we have discussed above. ${ }^{97}$ Grodecki noted that in the introduction to the third Livre d'architecture, Du Cerceau admonished patrons to commission a good drawing of their projected buildings before their construction:

95 Rosenfeld, "Sebastiano Serlio's Contributions," 184-85.

96 Catherine Grodecki, "La construction du château de Wideville et sa place dans l'architecture française du dernier quart du $\mathrm{xvI}^{\mathrm{e}}$ siècle," Bulletin Monumental, cxxxvi, no. II (1978), 164. Archives Nationales, Minutier Centrale, liv 202 (René Contesse).

97 Grodecki, "La construction," 148-49, figs. 7-8, 143, fig 10, 144, Morgan Library, Du Cerceau manuscript, folios 69 verso to 70 recto. The drawing of the façade on folio 70 recto is in the hand of Du Cerceau. Several different artists contributed to this model book. See note 78 . 
avant qu'cntrer en despense pour bastir est très nécessairc de adresser et arrester le plan et le desseing de l'édifice pour entendre les commoditez de dedans, tant du premier qu'autres estages de dessus, aussi la symmetrie par le dehors, afin que, le bastiment estant parfait, le maistre et seigncur d'iceluy n'ait regret à la despense par luy faicte... . ${ }^{98}$

It is important to emphasize that Du Cerceau intended the drawing of the project to be of use to both the patron and the master mason. Benoît Millon owned copies of Du Cerceau's Les plus excellents bastiments de France (1576-79) and of his Leçons de perspective positive (1576). ${ }^{99}$ Obviously patrons needed these reference books to be informed about the latest trends in architecture and to supervise the work of the architects and master masons they hired.

The cca's copy of the Détails d'ordres d'architecture, grand format was owned by one sculptor, one master mason, and one architect. It reveals that architects and master masons like Denis Fleury, as well as patrons like Benoît Millon, owned and used these publications. The process of constructing a building in the Renaissance involved the close collaboration of patron, architect, and master mason, as it does today. These model books were a means for all parties to be educated in the rudiments of architecture and share the same information. Du Cerceau, as we have seen, was a synthesizer and popularizer of designs for buildings and concepts of architectural theory. Through the medium of printing, he was able to bring these projects and ideas to a mass audience spanning many sectors of society. One of the major groups that used $\mathrm{Du}$ Cerceau's model books was the new class of bourgeois-gentilhommes who, like Benoît Millon, had acquired wealth and positions in the royal bureauc-

98 Grodecki, "La construction," 141: Du Cerceau, Le troisieme livre (Paris, 1582), folio 4 recto.

99 Grodecki, "La construction," note 17, 170), Archives . Vationales, Minutier Centrale, Inventory of Benoît Millon's House in Paris, rue de Béthisy, t.rv, 30I (July 1593). racy, which permitted them to enjoy many of the aspects of the life of the noble classes by acquiring fiefs and building castles for themselves. ${ }^{100}$ The second major group was the master masons and contractors. While they learned the art of masonry in the corporations to which they belonged, it was through the model books of publishers like Du Cerceau and the printed manuals of authors like Sebastiano Serlio that the masons acquired the knowledge of design and theory that was to transform them into architects. Long after Colbert founded the Royal Academy of Architecture in 1671 , these printed books were to continue to play a major role in the education of patron, architect, and contractor.

\section{DFIDICATION}

This article is dedicated to Janet Byrne, who has shared with me over the years her vast knowledge of Du Cerceau's oeuvre; and to Phyllis Lambert, whose personal interest in Du Cerceau has made it possible for the CCA to acquire a varied collection of his work, as well as for me to carry out research on Du Cerceau in New York, Paris, and Rome.

\section{$\triangle C K N O W L E D G M E N T S$}

I would like to thank Daphne Roloff, former head Librarian of the CCA; Cara Denison and Dr. Ruth Kraemer of the Morgan Library in New York; Dr. Hillary Ballon of Columbia University; Marianne Grivel, Maxime Préaud, and Jean Toulet of the Bibliothèque Nationale in Paris; Claire Béchu of the Minutier Centrale in Paris; Father Lconard Boyle, PhD, of the Bibliotheca Vaticana; Dr. Christoph Frommel and Dr. Dieter Graf of the Bibliotheca Hertziana in Rome; and Francesco Paolo Fiore of the University of Rome.

100 George Huppert, Les Bourgesis Gentilhommes (Chicago, 1977).

Centre Canadien d'Architecturel Canadian Centre for Archilecture 1920, rue Baile

Montréal, Québec H3H2S6 


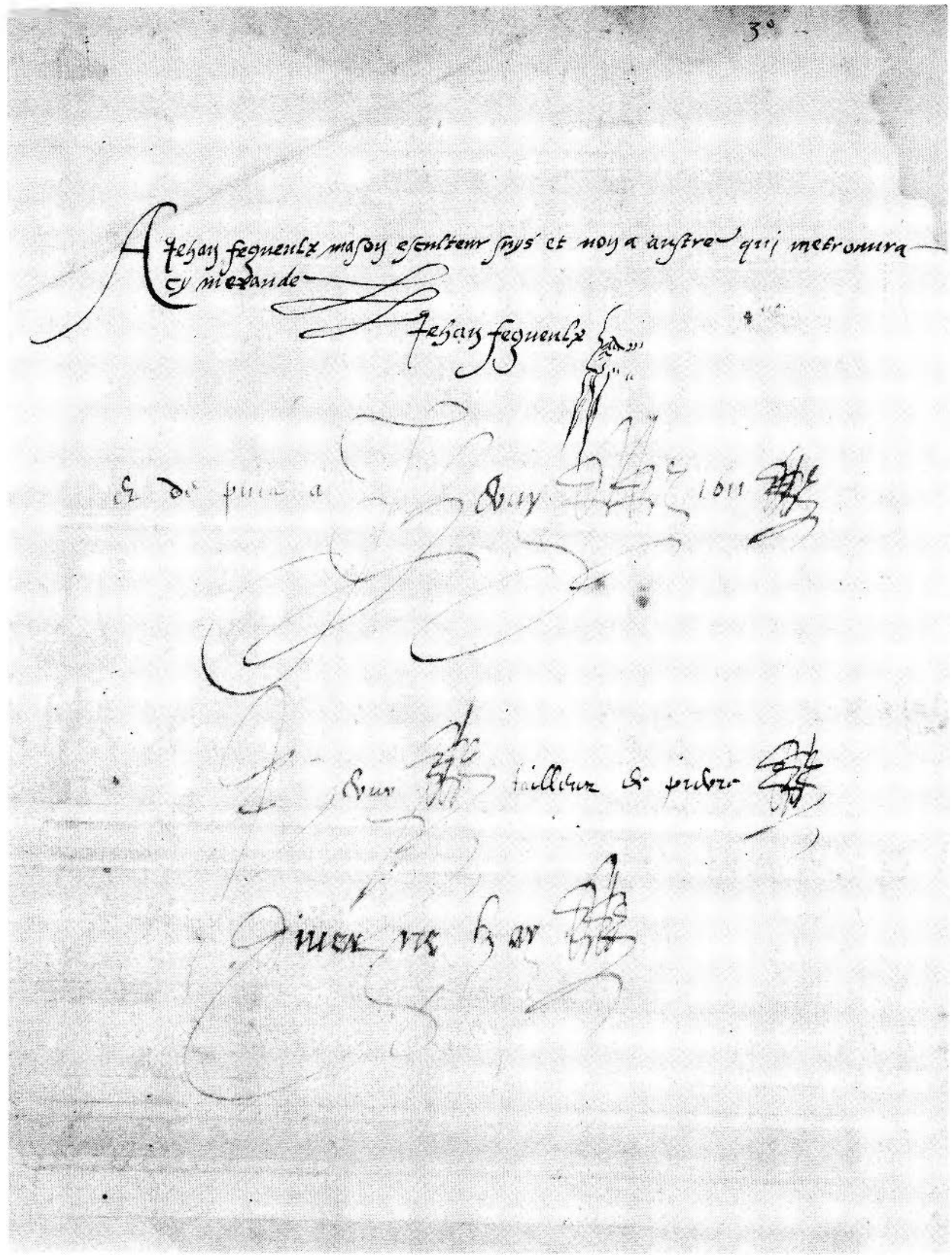

FigLRr. 131. Autographs of ()üners from Détails d'ordres d'architecture, grand format, folio 114 verso, pen and brown ink, $37.2 \times 24.2 \mathrm{~cm}$. IDX87-B9512, Collection Centre Canadien d'Architecture/Canadian Centre for Architecture, Montréal. 


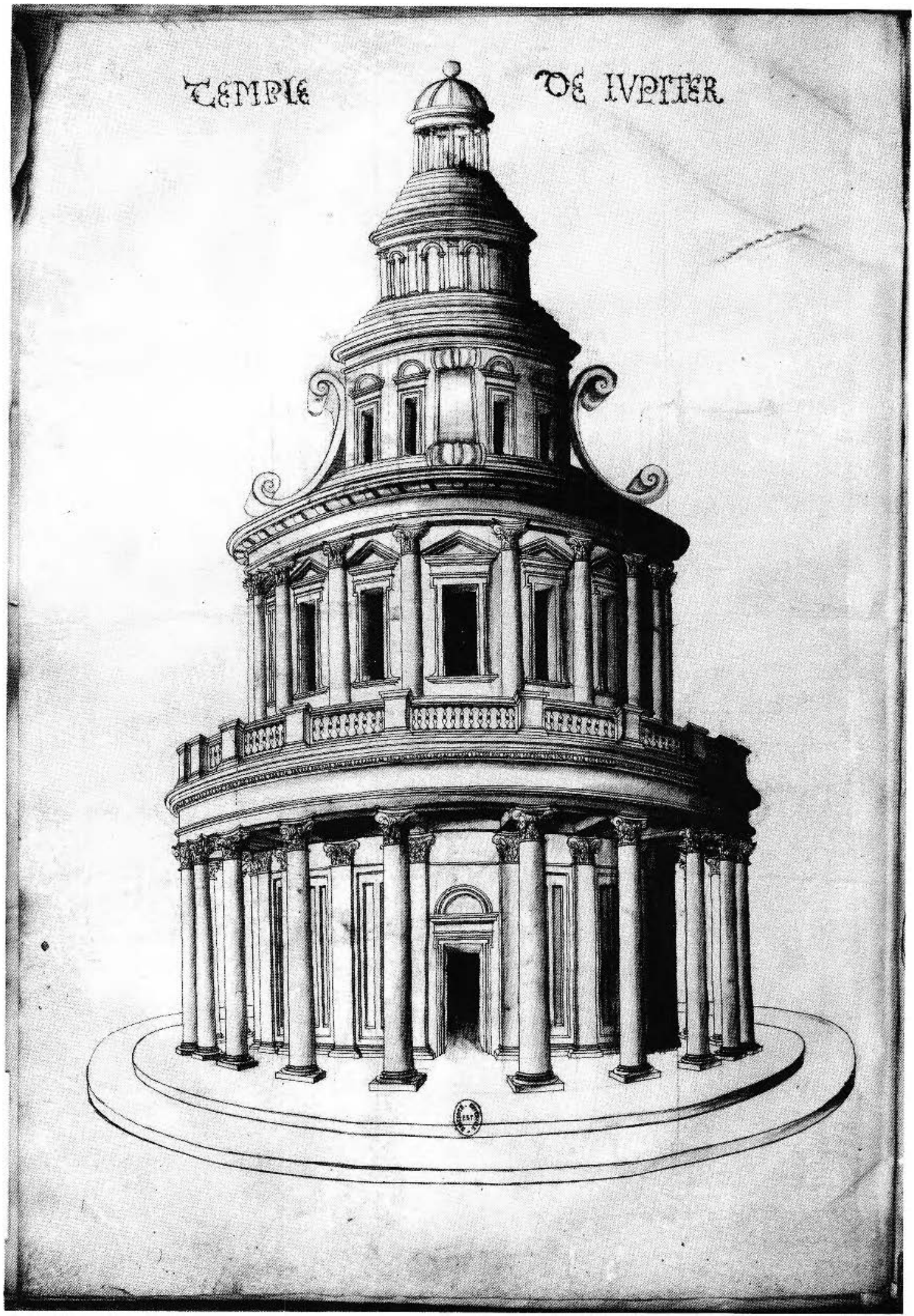

Figure 132. Workshop of Jacques Andronet Du Ccrceau, View of the So-called Temple of Jupiter, pen, black ink and grey wash on vellum, $1550-80,31.2 \times 45.2 \mathrm{~cm}$. F.d. $2 \mathrm{r}$, folio 3 verso, Paris, Bibliothèque Nationale, Réscrve du Cabinet des Estampes. 


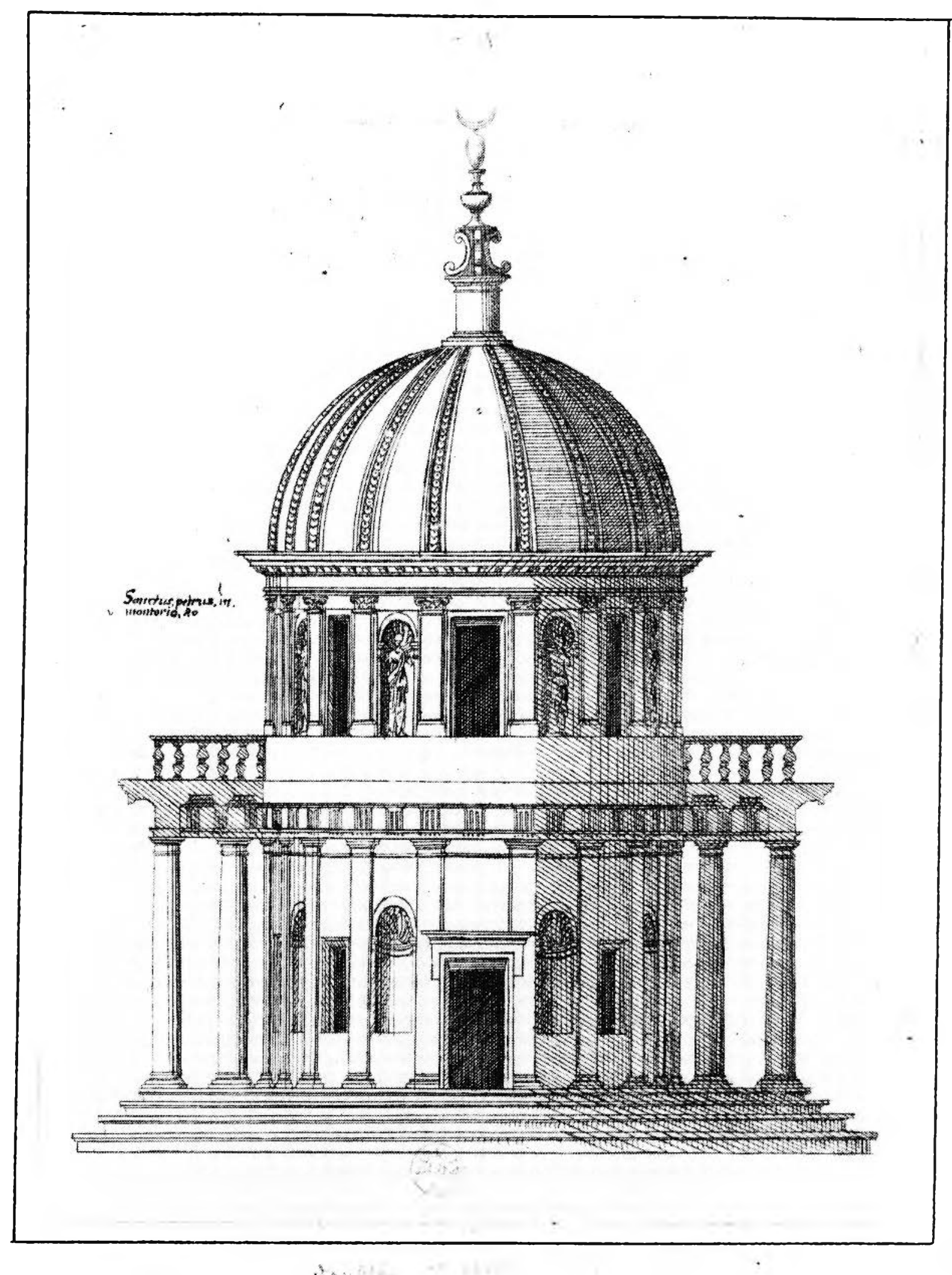

Figurf 133. Jacques Androuet Du Cerceau, France, Paris about 1520-Paris, about 1586, Moyens Temples, ()rléans, 1550, folio 5 recto, View of the Church of San Pietro in Montorio, Rome, engraving, $13.2 \times 9.5 \mathrm{~cm}$. F.d. 2c, Paris, Bibliothèque Nationale, Cabinet des Estainpes. 


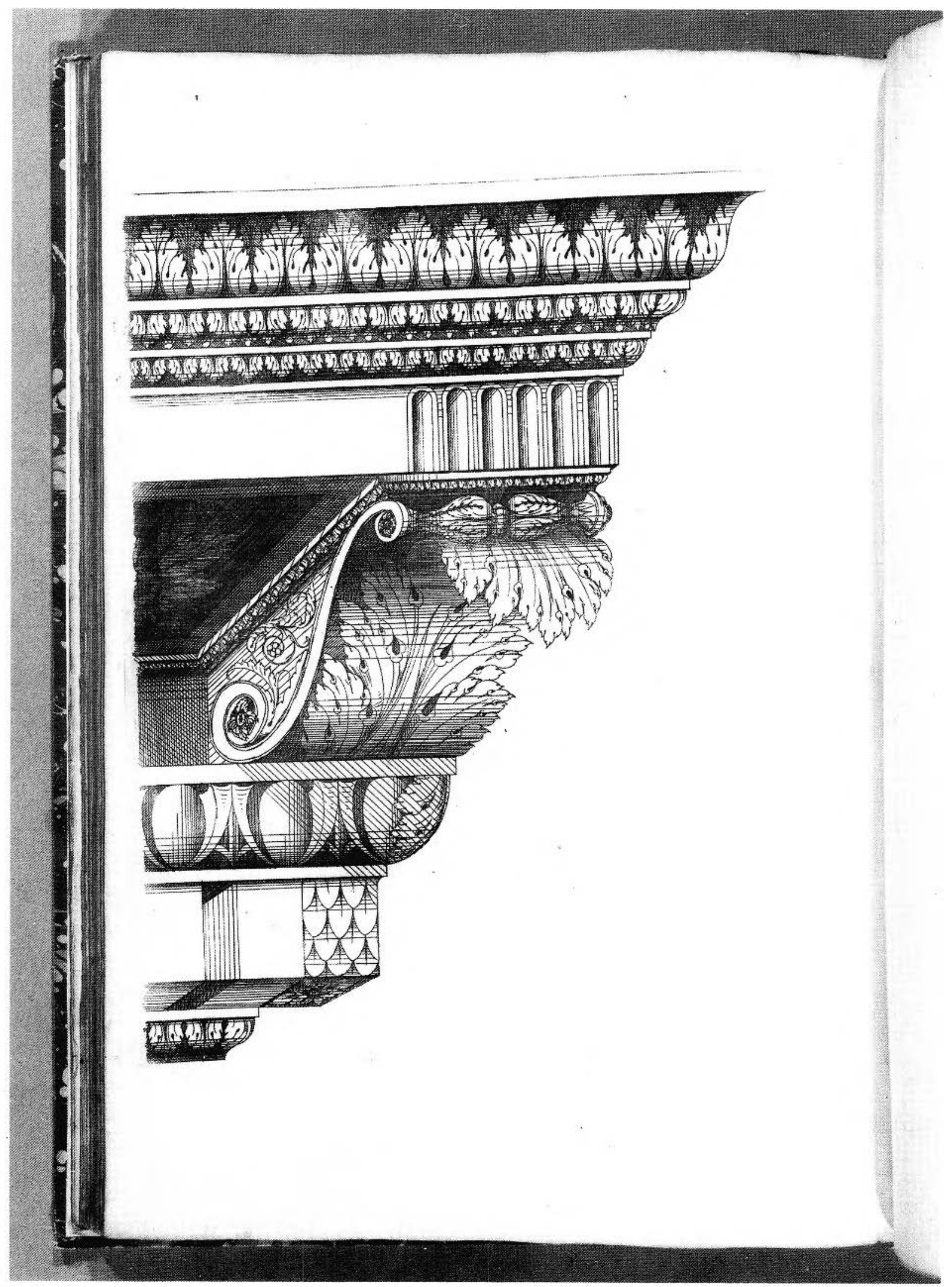

Figlikf 134. Workshop of Jac(pues Androuet Du Cerceau, Délails d'ordres d'arrhitecture, grand format, $1550-80$, folio 86 rerso, Détcil of the Comice of the Temple of Concord, Rome, engraving, $37.2 \times 24.2 \mathrm{~cm}$. IDX87-B9152, Collection Centre Canadien d'Architecture/Canadian Centre for Architecture, Montréal. 


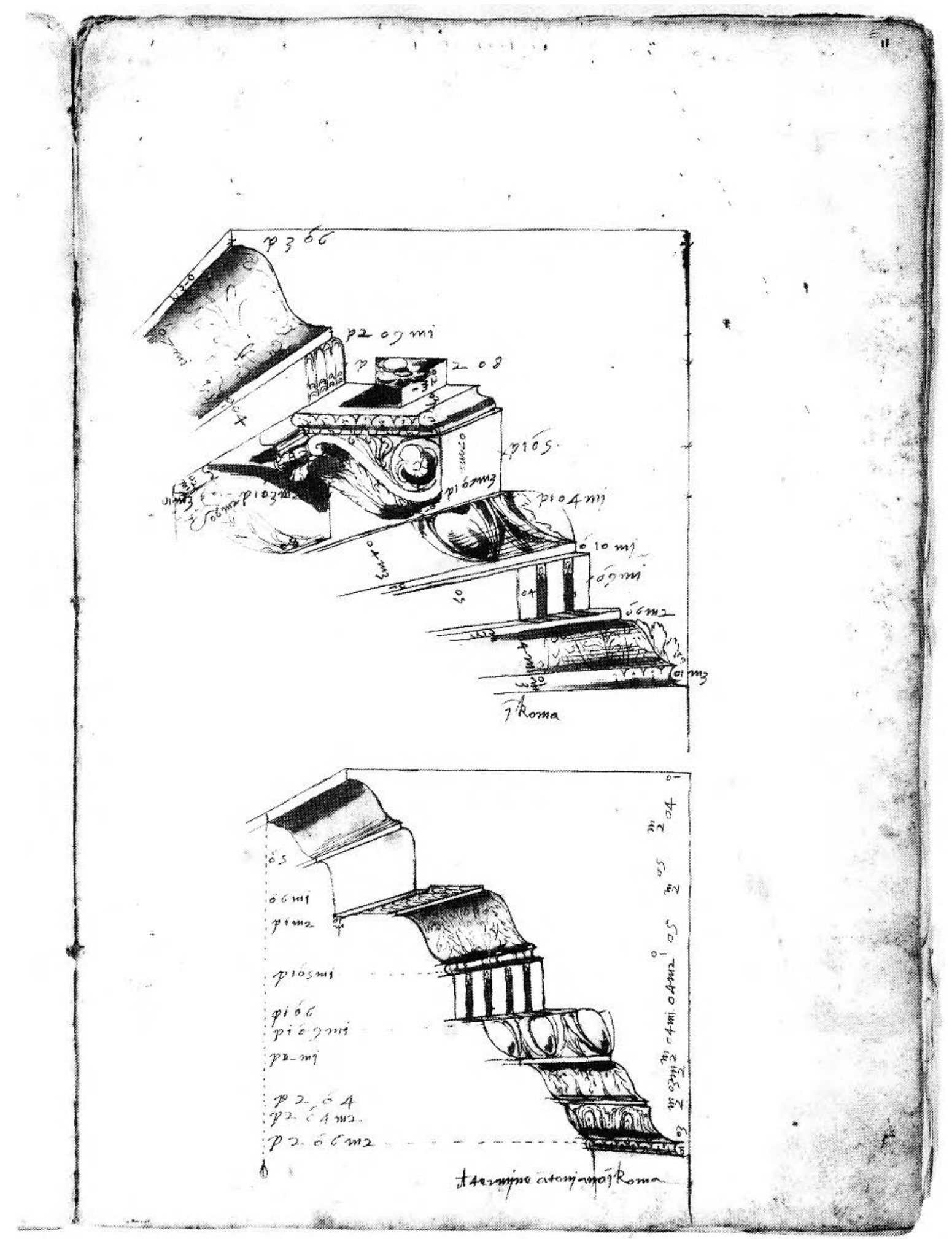

Figure 135. Unknown Italian Artist, active in Rome, first half of the sixteenth century, Detcils of Two Cornices, pen, brown ink, brown wash, over graphite and stylus underdrawing on laid paper, about $1530,32.5 \times 22.8 \mathrm{~cm}$. DR 1982:0020:009 recto, Collection Centre Canadien d'Architecture/Canadian Centre for Architecture, Montréal. 


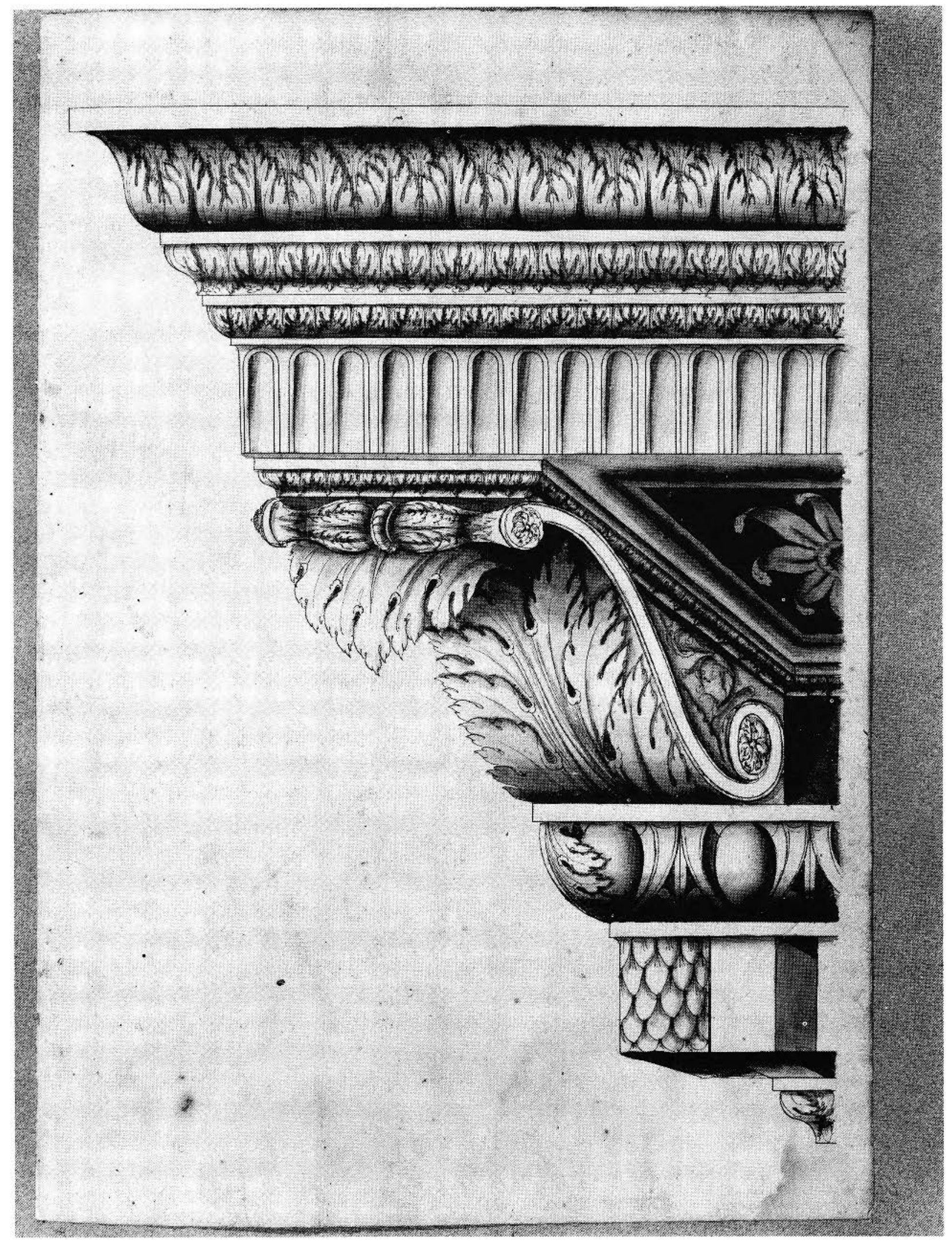

Figure 136. Workshop of Jacques Androuet Du (erceau, Detail of the Cornice of the Temple of Concord, pen, black ink. and grey wash, over graphite and stylus underdrawing on laid paper, about $1545-50,38.8 \times 27.4 \mathrm{~cm}$. I)R 1974:0001:012recto, Collection C'entre Canadicn d'Architecture/Canadian Centre for Architecture, Montréal. 


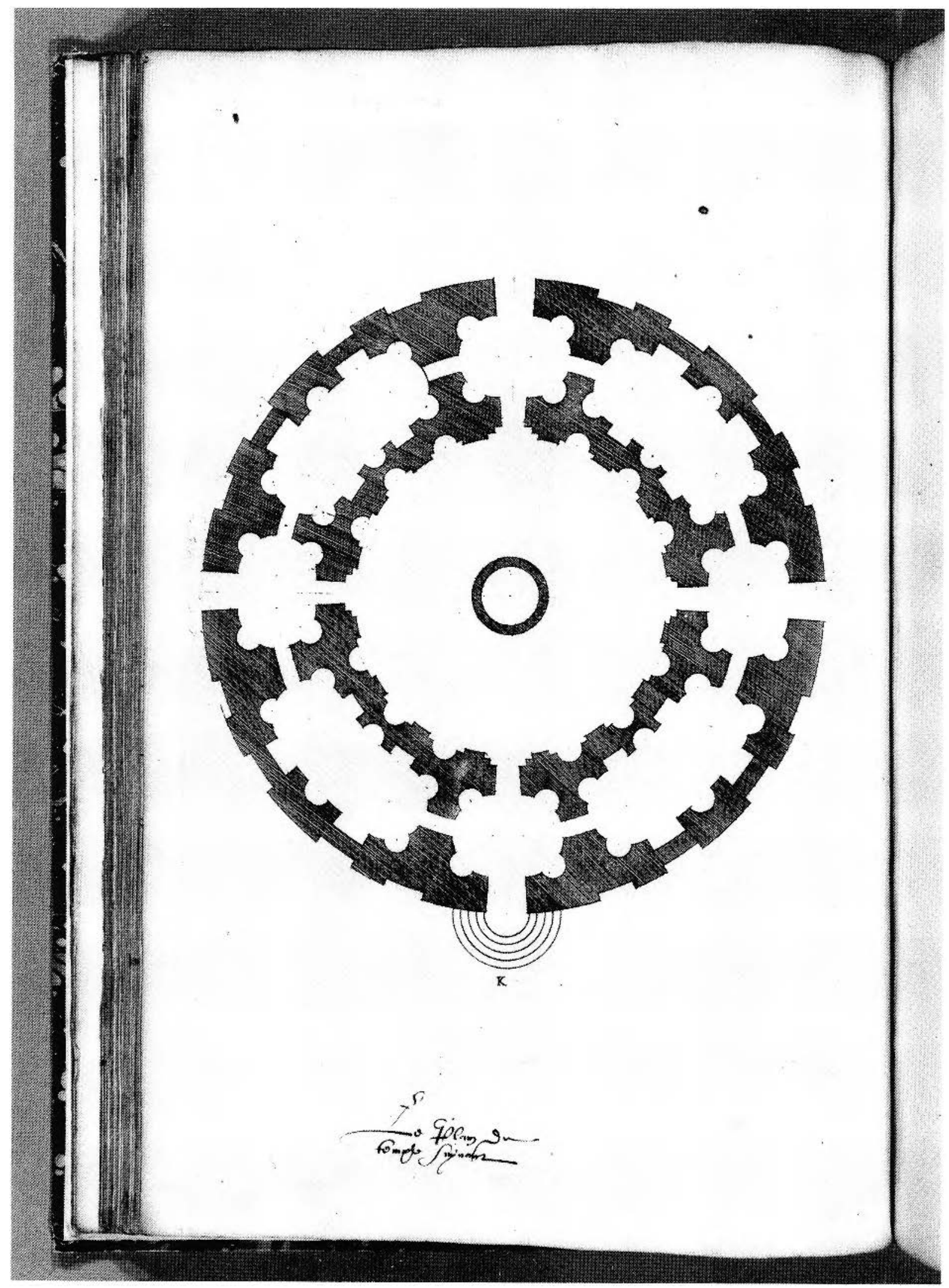

Figler 137. Workshop of Jacques Androuct Du Cercealu. Temples el habitations fortifies, 1545-50), folio 51 verso, Ground Plan of Project K, engraving, $37.2 \times 24.2 \mathrm{~cm}$. I1)X87-B9152, Collection Centre Canadien d'Architccture/ Canadian Centre for Architecture, Montréal. 


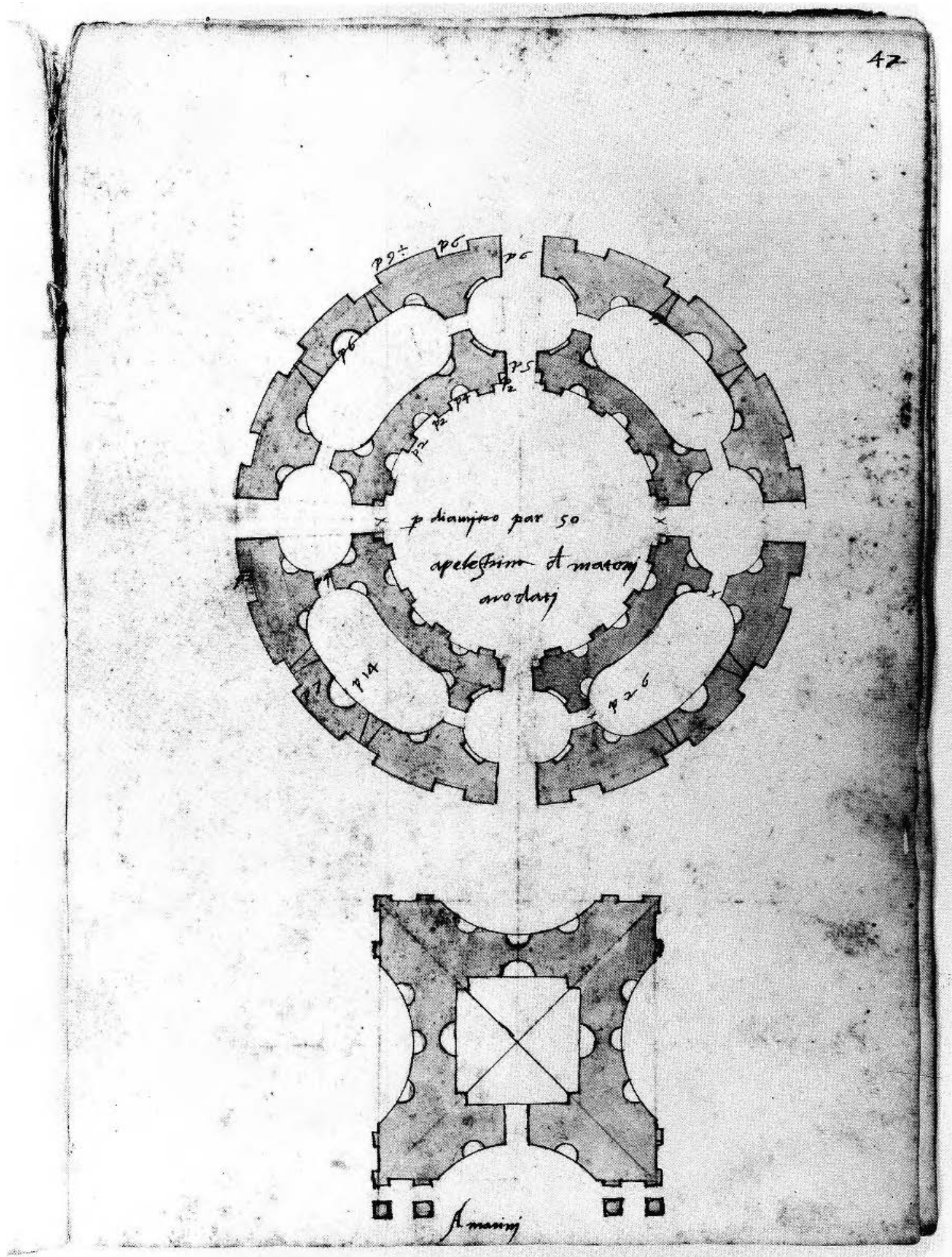

FIgURE 138. Unknown Italian Artist, active in Rome, first half of the sixteenth century, Ground Plan of a Chamber of a Roman Villa Near Palestrina and Ground Plan of the Tomb at Santa Maria Capua Vetere, pen, brown ink, brown wash, over graphite and stylus underdrawing on laid paper, about 1530,32.5 × 22.8 cm. DR1982:0020:018 recto, Collection Centre Canadien d'Architecture/Canadian Centre for Architecture, Montréal. 


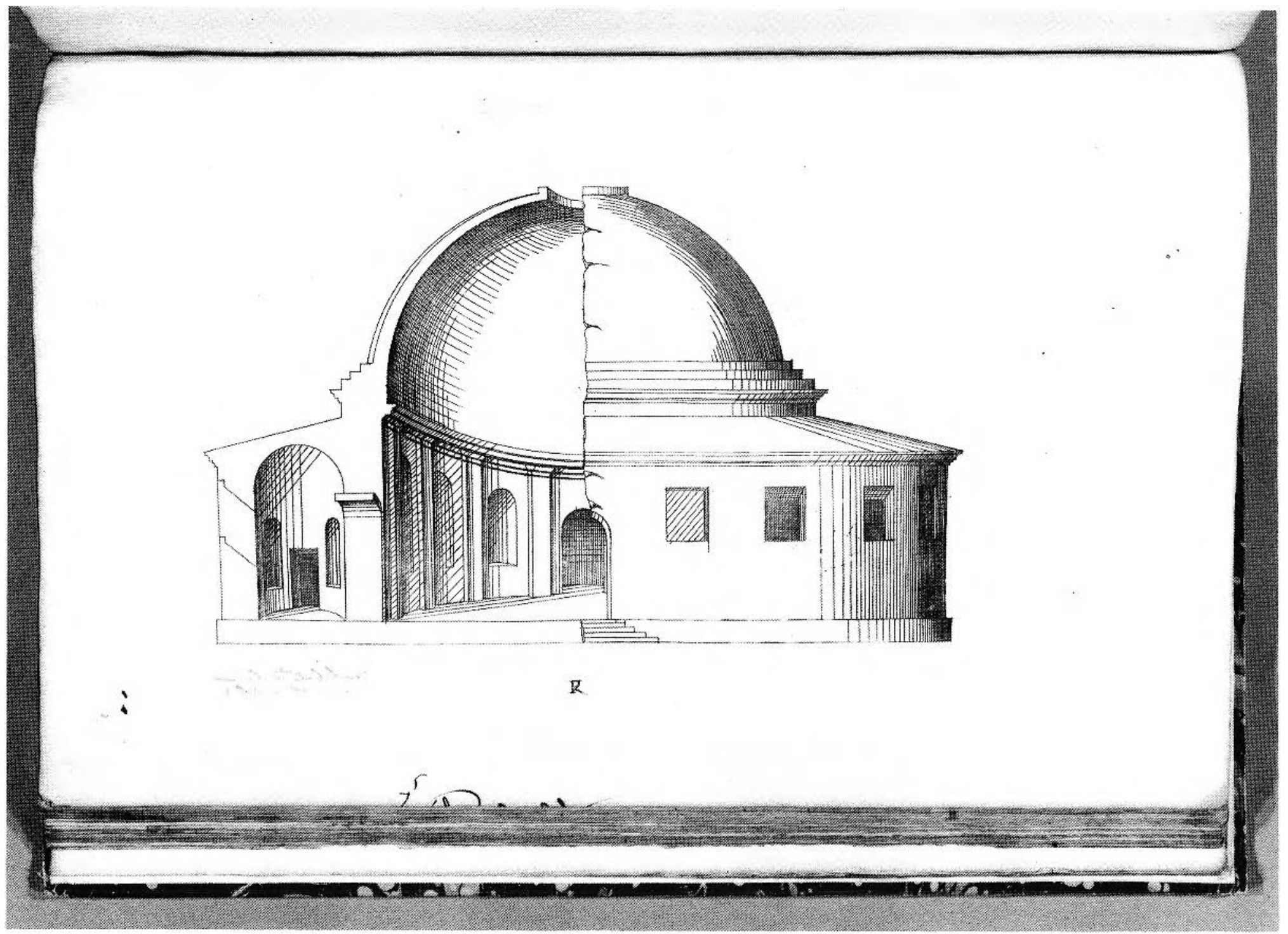

Figlre. 139. Workshop of Jacques Androuet Du Cerceau, Temples et habitations fortifiés, 1545-50, folio 52 verso, Combined View of the Interior and Exterior of Project K, engraving, $37.2 \times 24.2 \mathrm{~cm}$. IDX87-B9152, Collection Centre Canadien d’Architecture/Canadian Centre for Architccture, Montréal. 


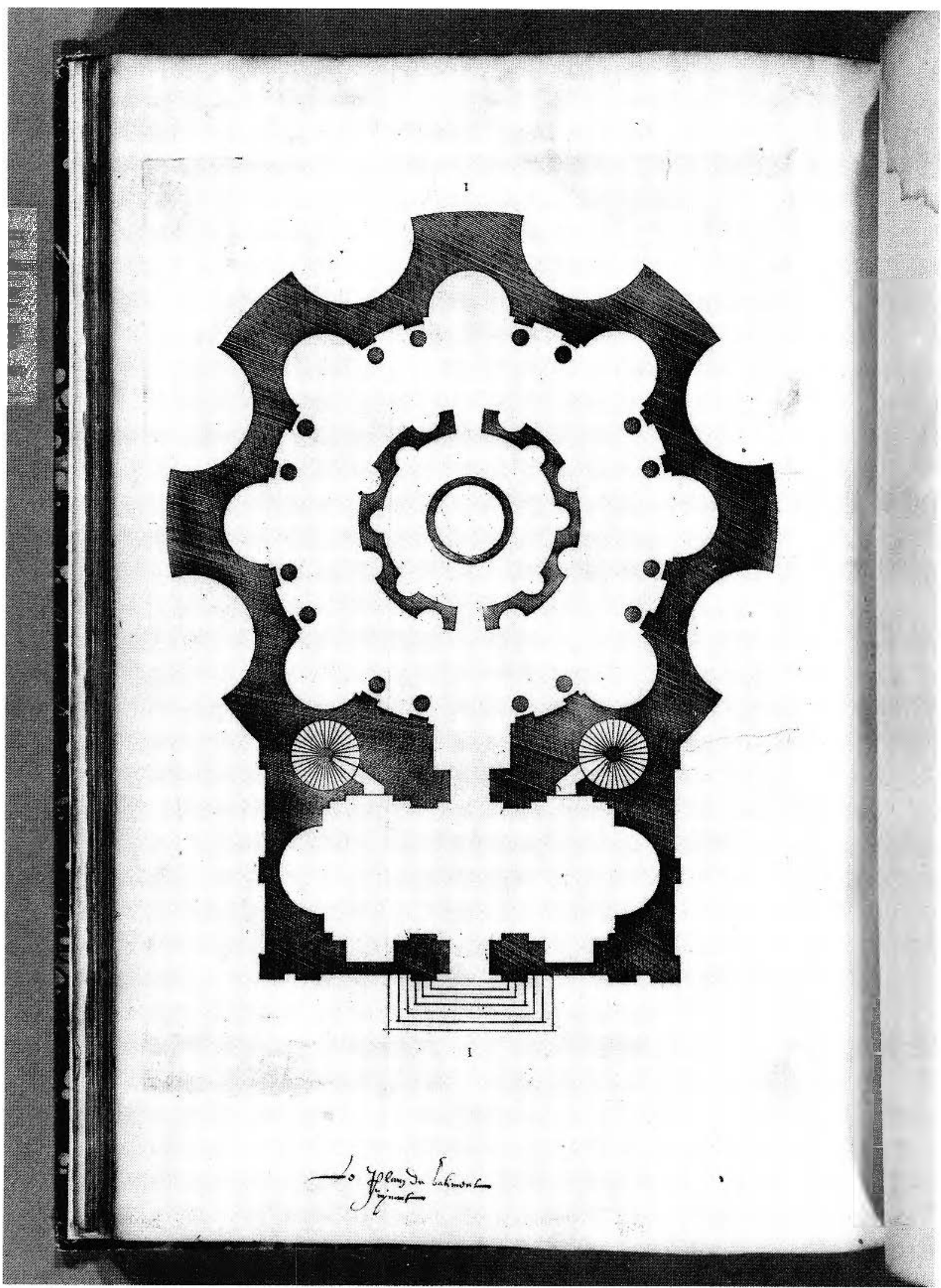

Figure 140. Workshop of Jac(ues Androuct Du (erceau, Temples et habitations fortifiés, 1545-50, folio 77 verso, Ground Plan of Projectl, engraving, $37.2 \times 24.2 \mathrm{~cm}$. II) $878-\mathrm{B} 9152$, Collection Centre Canadien d'Architecture/ Canadian Centre for Architecture, Montréal. 


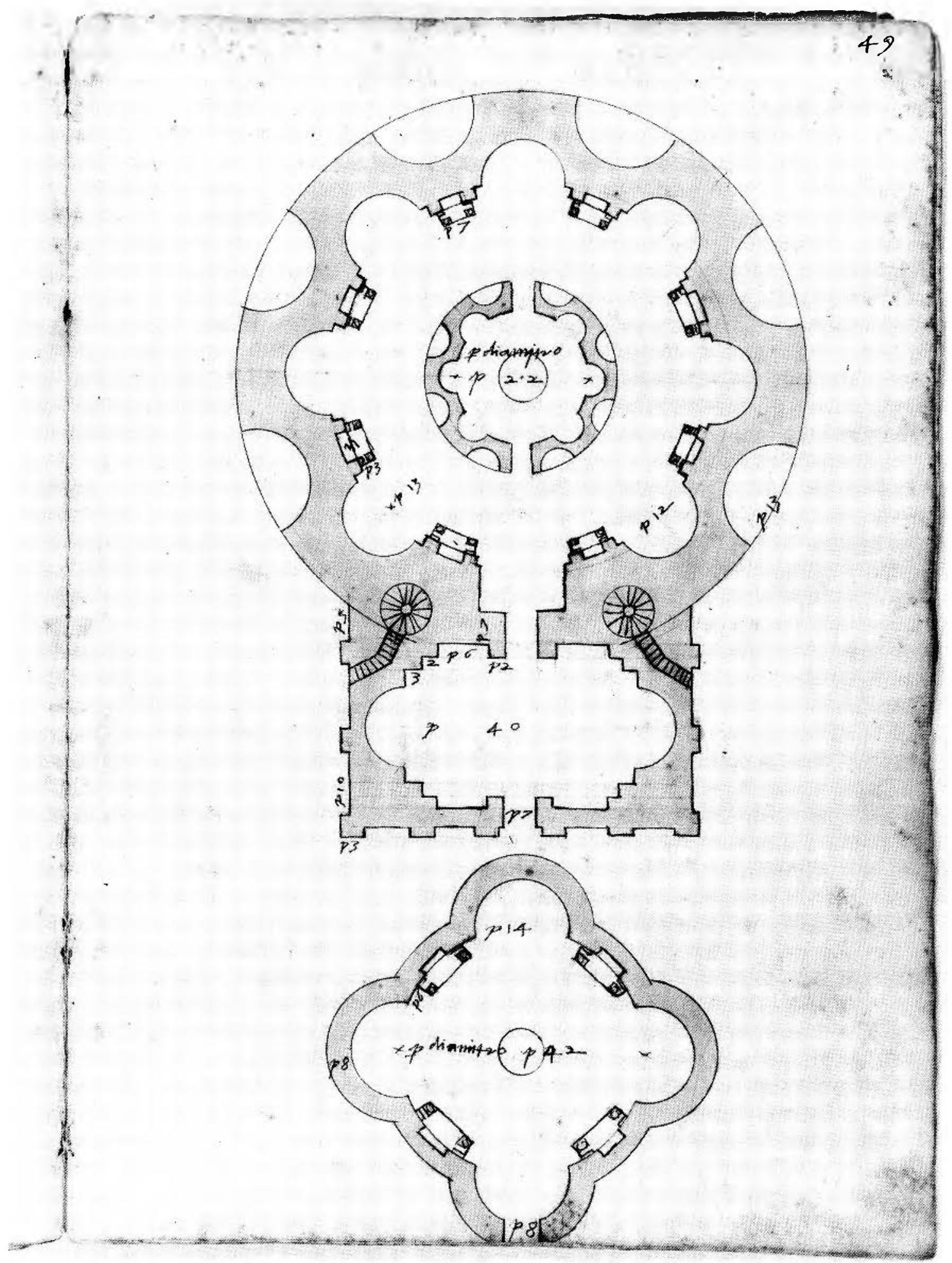

Figurf: 141. Unknown Italian Artist, active Rome, first half of the sixteenth century, Ground Plan of the Tomb of Romulus on the Via Appia, Rome, and Ground Plan of an Unidentified Structure, pen, brown ink, brown wash, over graphite and stylus underdrawing on latid papcr, about 1530, 32.5 × 22.8 cm. DR 1982:0020:()20, Collection Centre Canadien d'Architecture/Canadian Centre for Architecture, Montréal. 


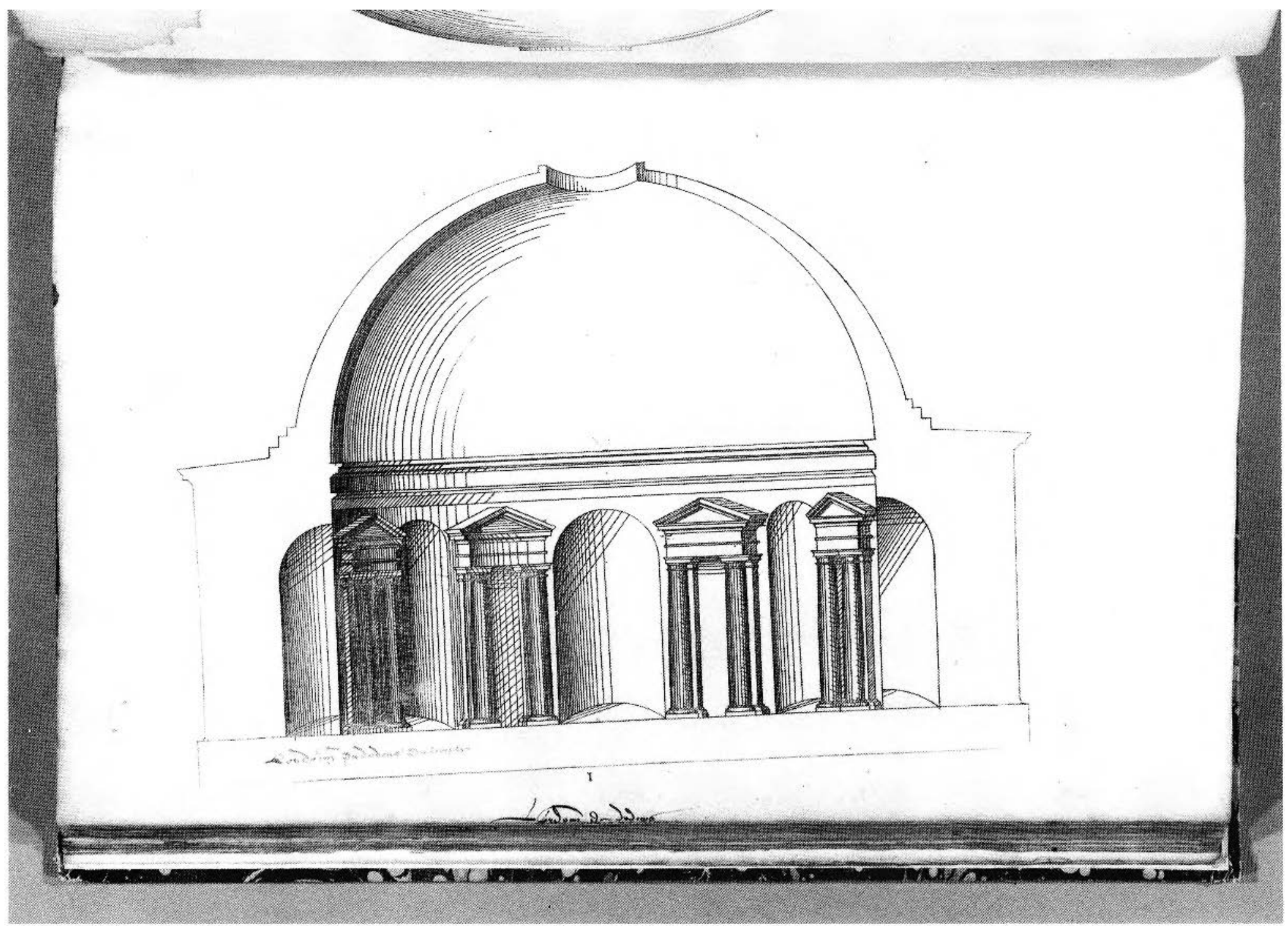

Figure 142. Workshop of Jacques Androuet Du Cerceau, Temples el habitations fortifiés, 1545-50, folio 78 verso, Cross-section of Project I, engraving, $37.2 \times 24.2 \mathrm{~cm}$. IDX87-B9152, Collection Centre Canadien d'Architecture/ Canadian Centre for Architccture, Montréal. 


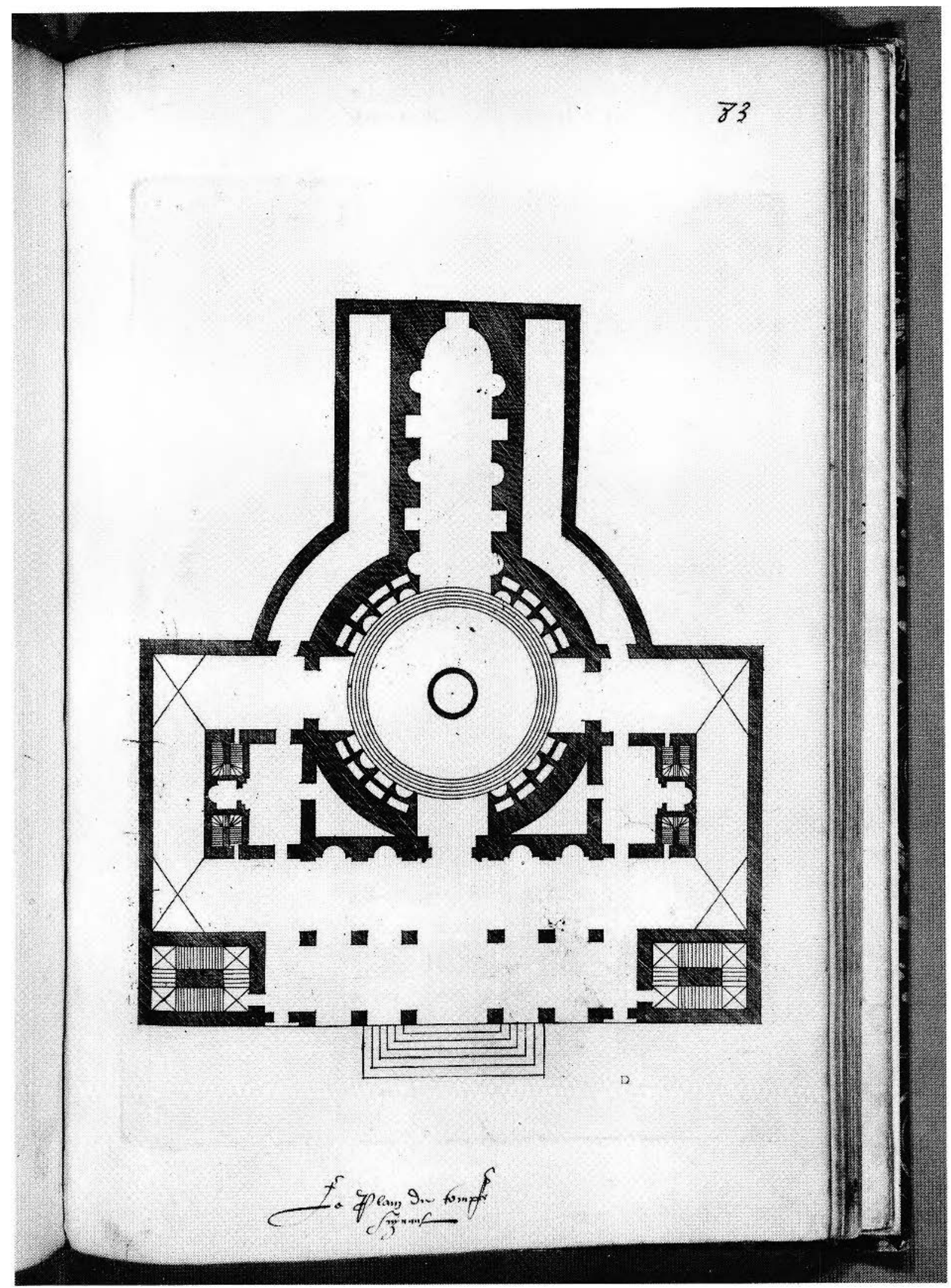

Figurf: 143. Workshop of Jacques Androuct Du Cerceau, Temples et habitations fortifiés, 1545-50, folio 8.3 recto, Ground Plan of Project D, engraving, $37.2 \times 24.2 \mathrm{~cm}$. IDX87-B9152, Collection Centre Canadien d'Architecture/ Canadian Centre for Architecture, Montréal. 


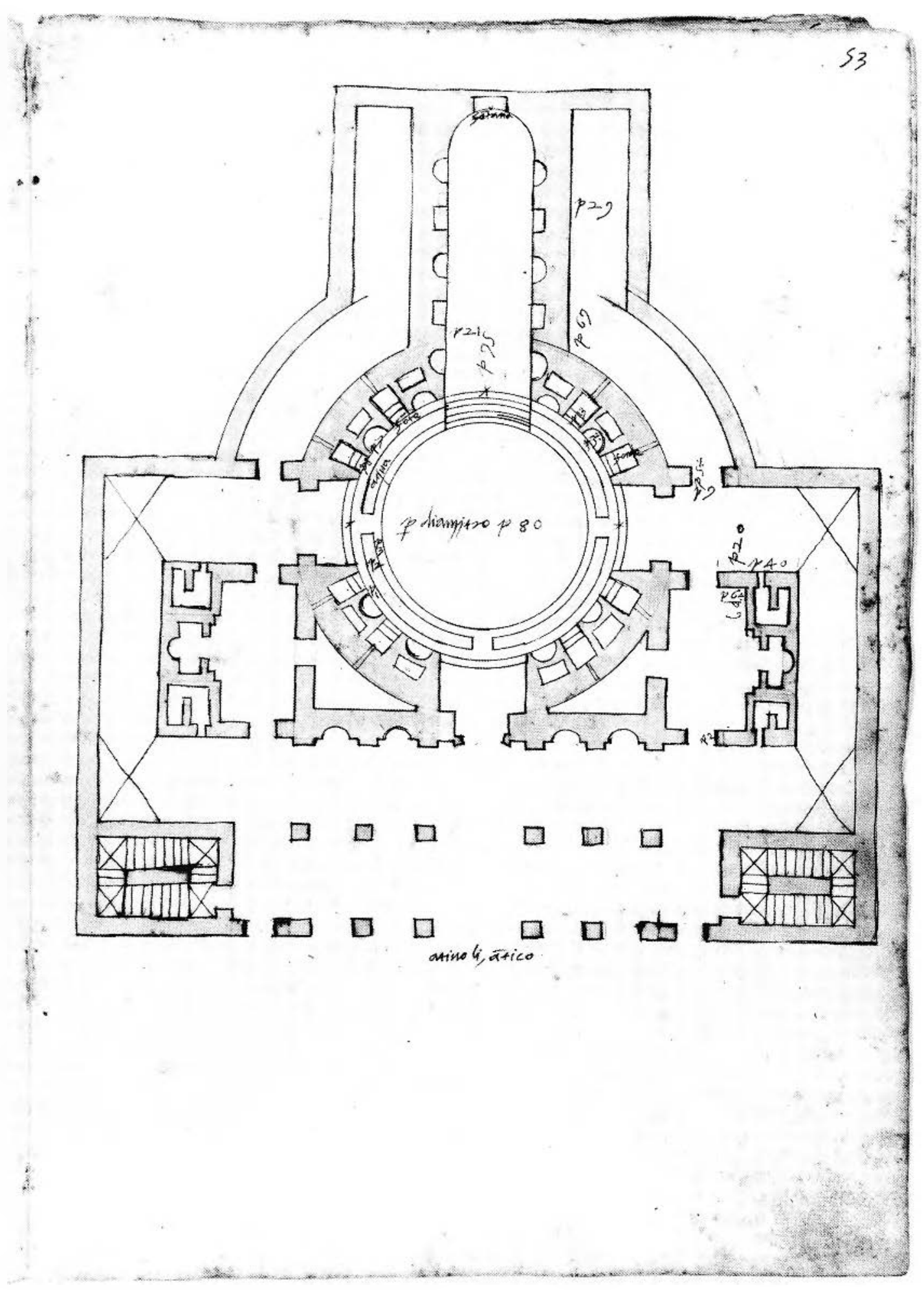

Ficitre. 144. Lnknown Italian Irtist, active Rome, first half of the sixteenth century, Ground Plan of the Serapaeum of Hadrian's Villa at Tizoli, pen, brown ink, brown wash over graphite and stylus underdrawing on laid paper, about 1530 , $32.5 \times 22.8 \mathrm{~cm}$. DR: 1982:002():024, Collection Centre Canadien d'Architecture/Canadian Centre for Architecture, Montréal. 


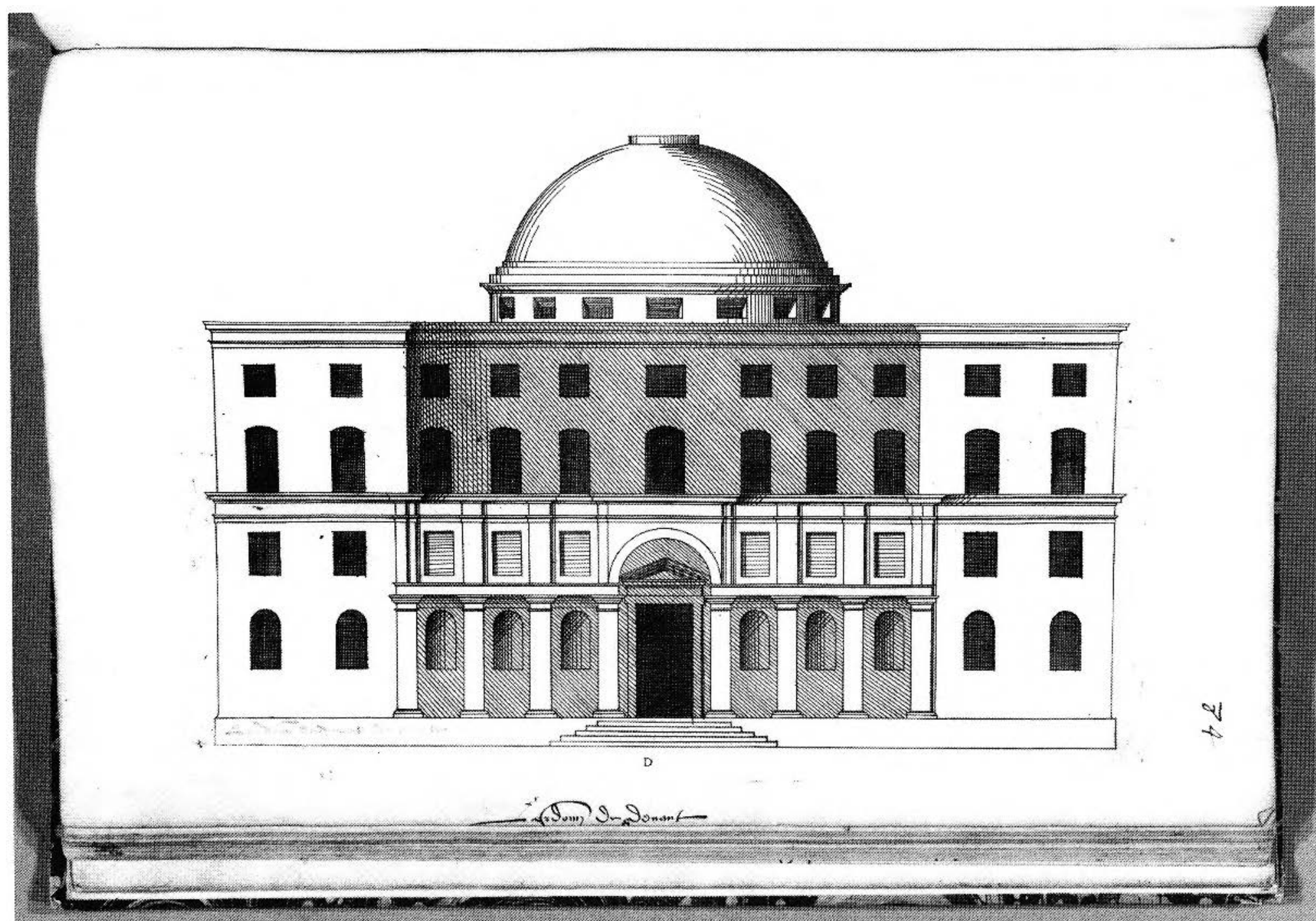

Figure: 145. Workshop of Jacques Androuce dou Cerceau, Temples el habitations fortifiés, 1545-50, follio 84 recto, Elevation of the Fasade of Project D), engraving, $37.2 \times 24.2 \mathrm{~cm}$. 11)X87-B9152, Collection Centre Canadien d'Architecure/Canatlian Centre for Architecture, Montréal. 


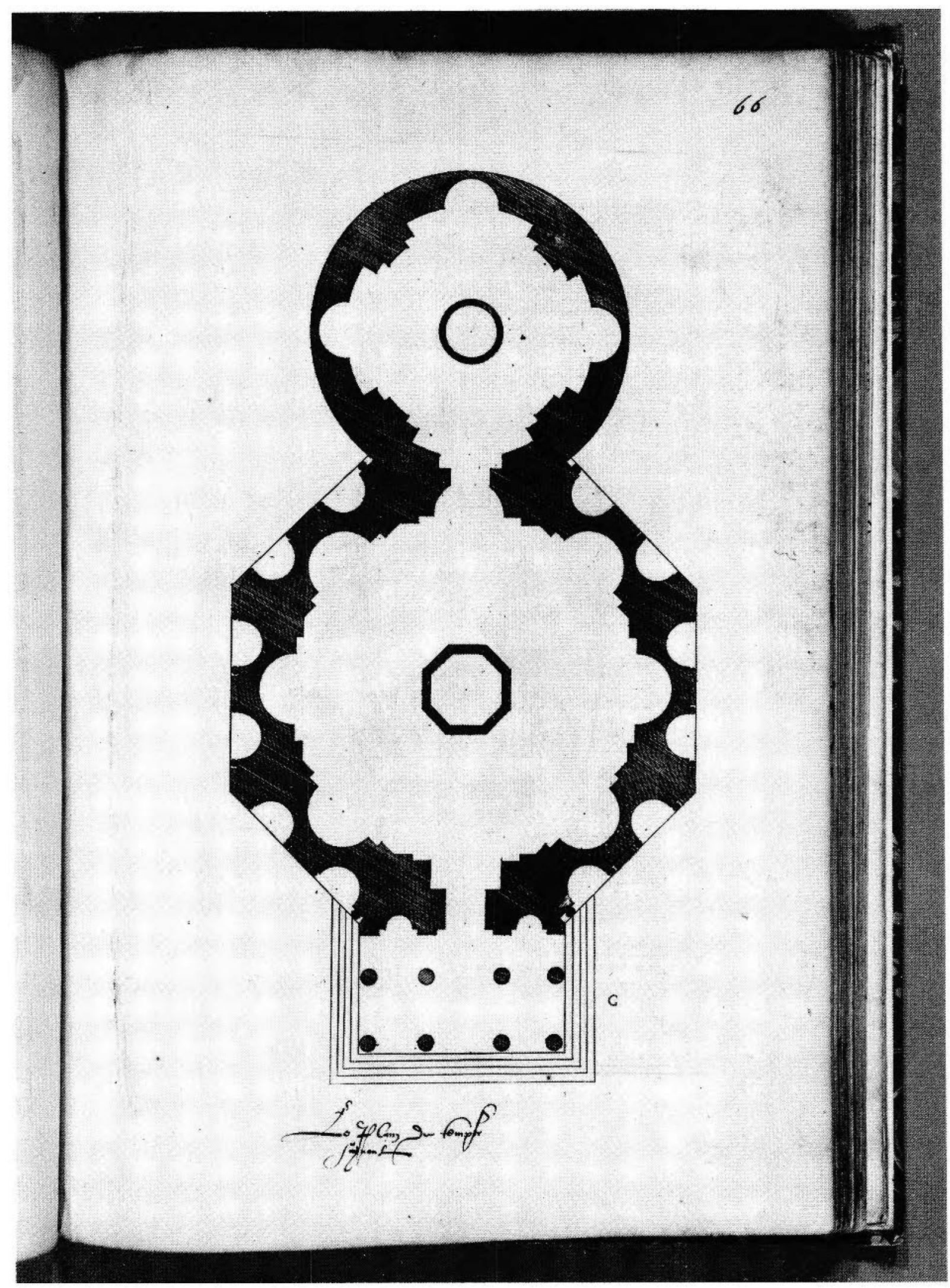

Ficiurr. 146. Workshop of Jacques Androuct Du Cerceau, Temples et habitations fortifiés, 1545-50), folio 66 recto, Ground Plan of P'roject G, engraving, $37.2 \times 24.2 \mathrm{~cm}$. IDX87-B9152, Collection Centre Canadien d'Architccture/ Canadian Cicntre for Architecture, Montréal. 


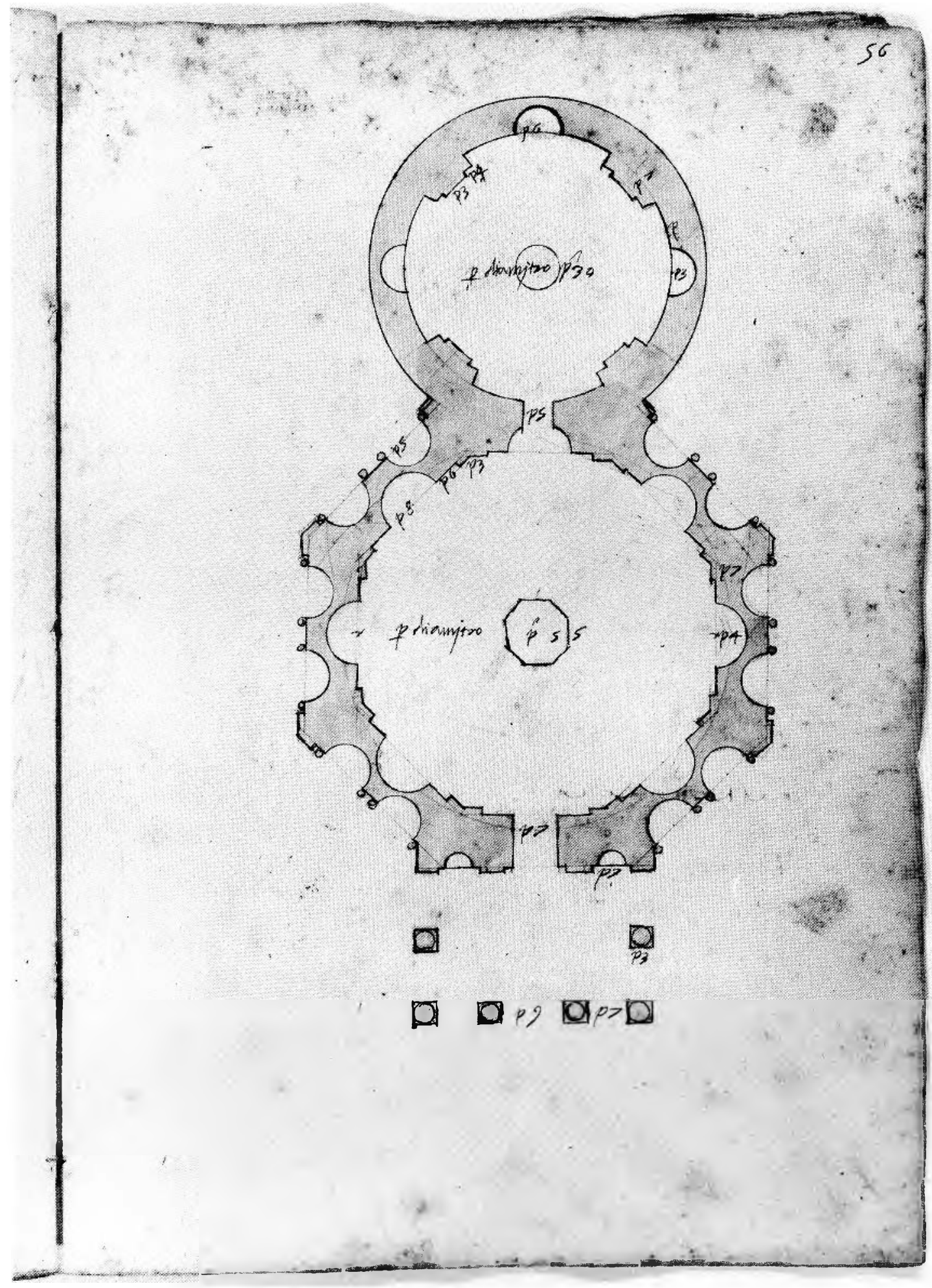

Figurf: 147. Unknown Italian Artist, active Rome, first half of the sixteenth century, Ground Plan of the Cienolaph of Antinous, Rome, pen, brown ink, brown wash, over graphite and stylus underdrawing on laid paper, about. 15.30, $32.5 \times 22.8 \mathrm{~cm}$. I)R:1982:0020:027, Collection Centre Canadien d'Architecturc/Canadian Centre for Architecture, Montréal. 


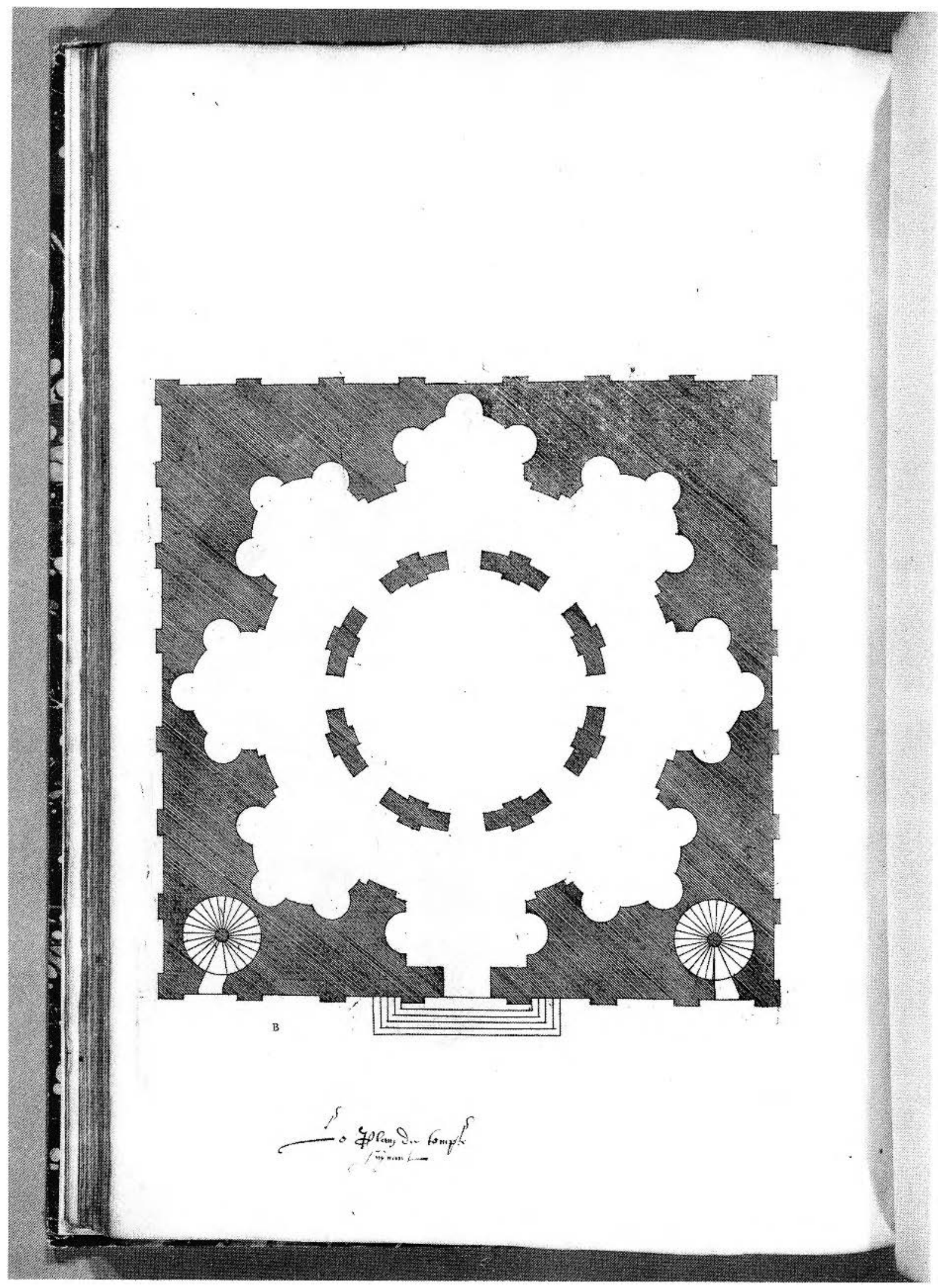

Figurt 148. Workshop of Jaçues Androuet Du Cerceau, Temples et habitations fortifiés, 1545-50, folio 75 verso, Ground Plan of Project B, engraving, $37.2 \times 24.2 \mathrm{~cm}$. IDX87-B9152, Collection Centre Canadien d'Architecture/ Canadian Centre for Architecture, Montreal. 


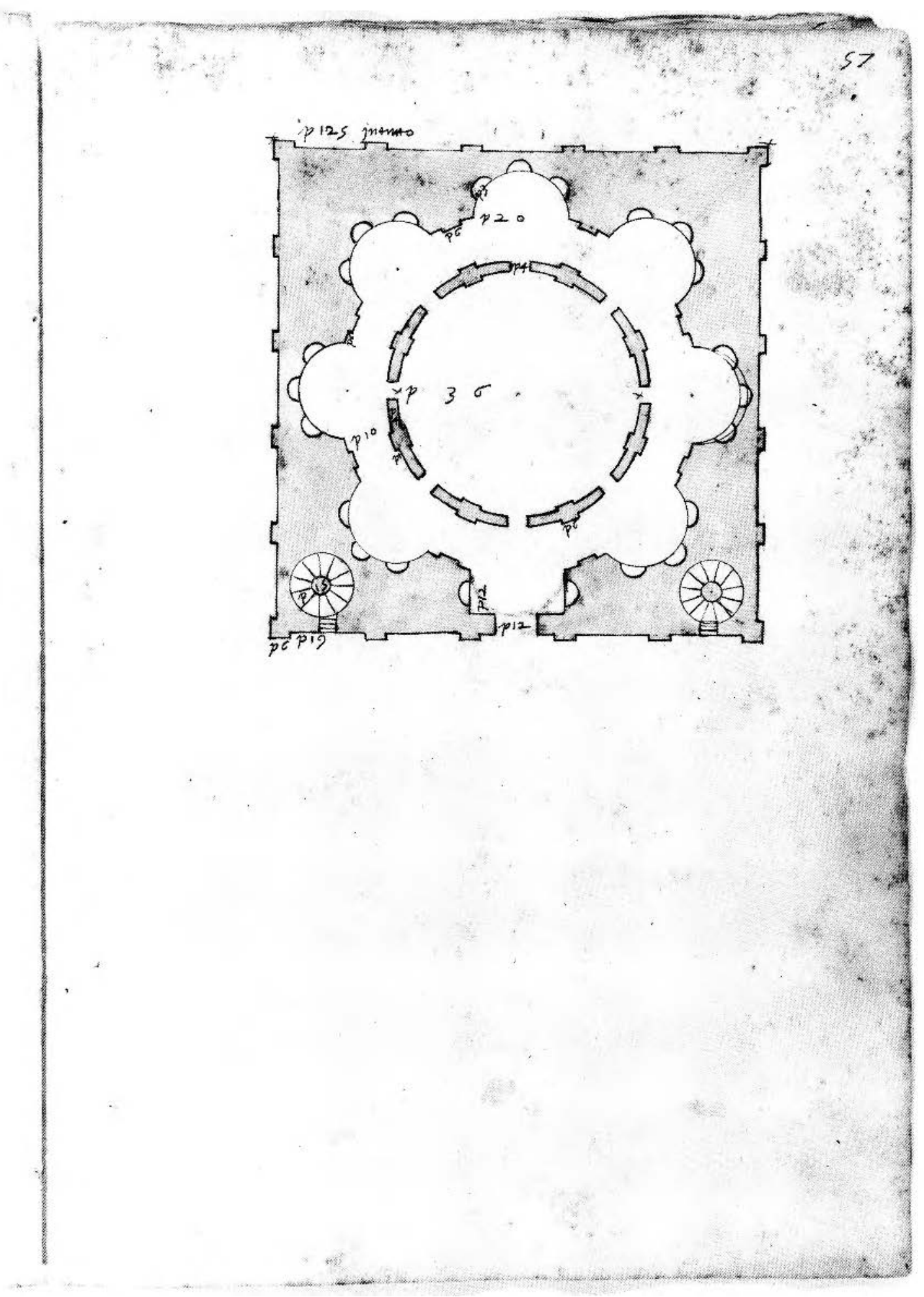

Figure 149. Lnknown Italian Artist, active Rome, first half of the sixteenth century, Ground Plan of the Church of SS. Cielso and Giuilano, Rome, pen, brown ink, brown wash over graphite and stylus underdrawing on laid paper, about 1530, 32.5 × 22.8 cm. DR: 1982:0020:(028, Collection Centre Canadien d'Architccture/Canadian Centre for Architecture, Montréal. 


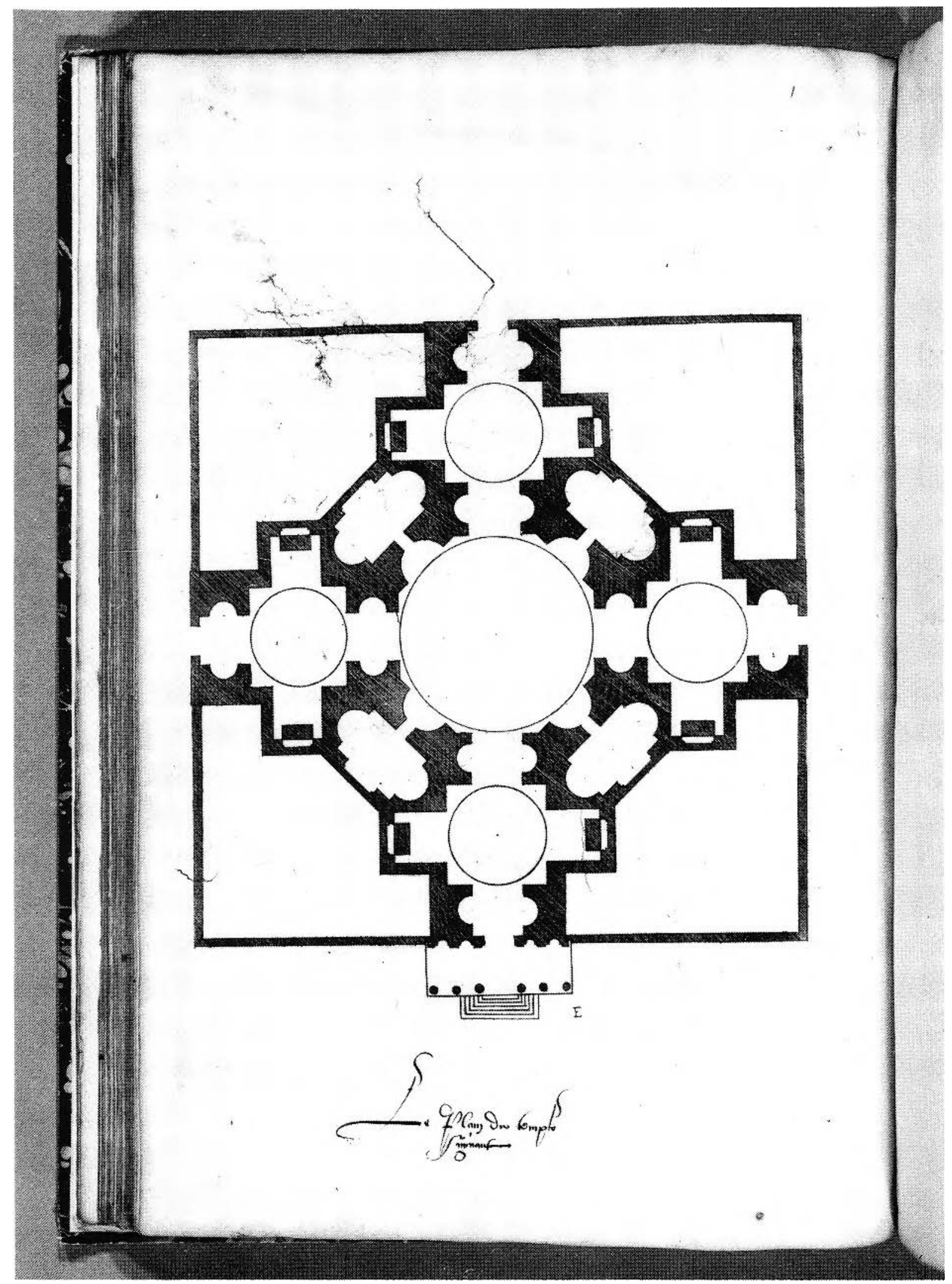

Figure 150. Workshop of Jacques Androuet Du (Cerceau, Temples et habitations fortifiés, 1545-50), folio 60 verso, Plan of Project E, engraving, $37.2 \times 24.2 \mathrm{~cm}$. IDX87-B9152, Collection Centre Canadien d'Architecture/Canadian Centre for Architecture, Montréal. 


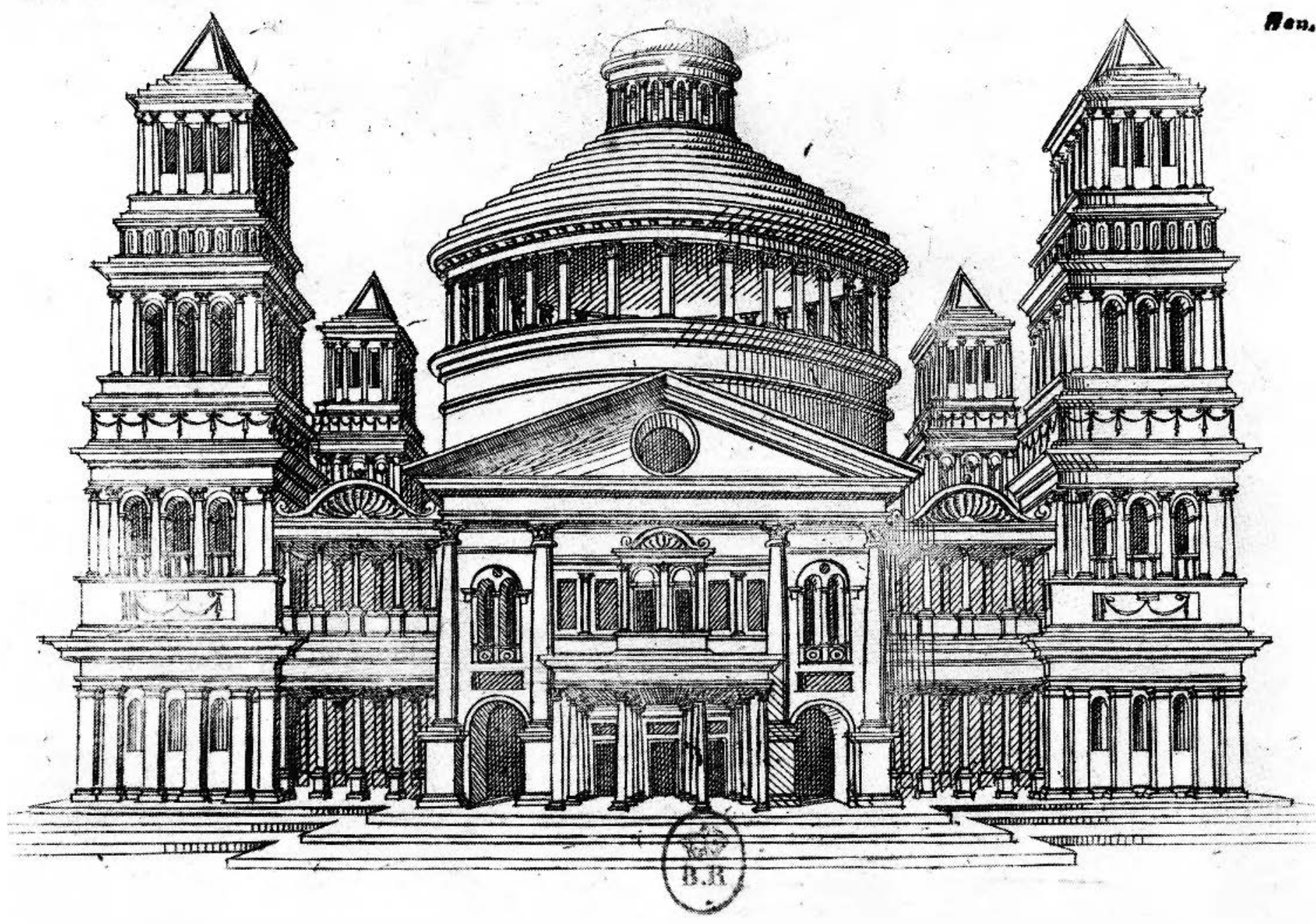

Figlre 151. Jacques Androuct Du Cerceau, France, Paris about 152()-Paris, about 1586, Moyens Temples, Orléans, 15.50), folio 24. Façade of St. P'eter's after a P'roject by Raphael, engraving, $13.2 \times 9.5 \mathrm{~cm}$. Ed. 2c, Paris, Bibliothèque Nationale, Cabinct des Estampes. 


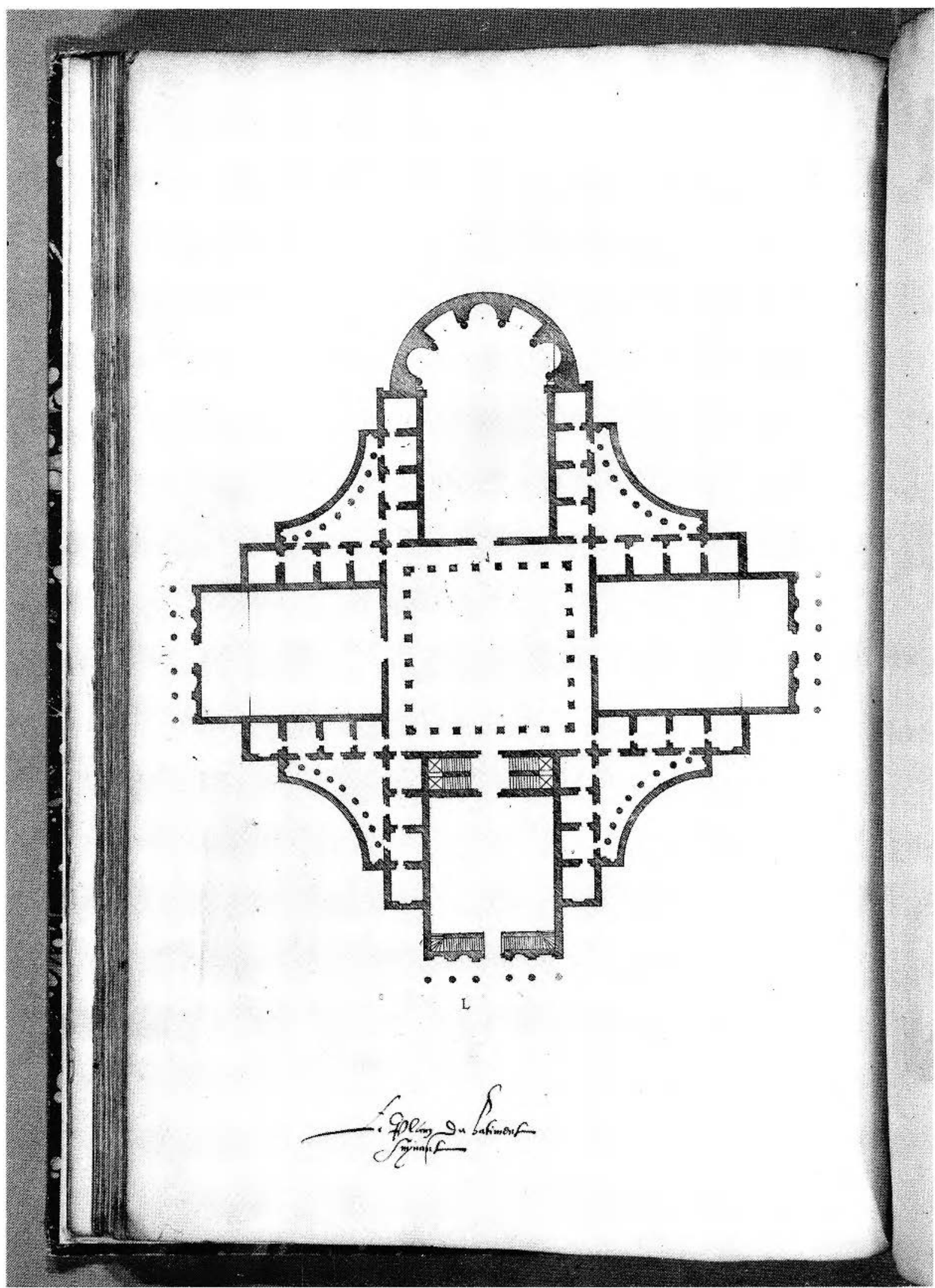

Figurf 152. Workshop of Jacques Androuet Du Cerceau, Temples et habitations fortifiés, 1545-50, folio 53 verso, Ground Plan of Project L, cngraving, $37.2 \times 24.2 \mathrm{~cm}$. IDX87-B9152, Collection Centre ('anadien d'Architecture/ Canadian Centre for Architecture, Montréal. 


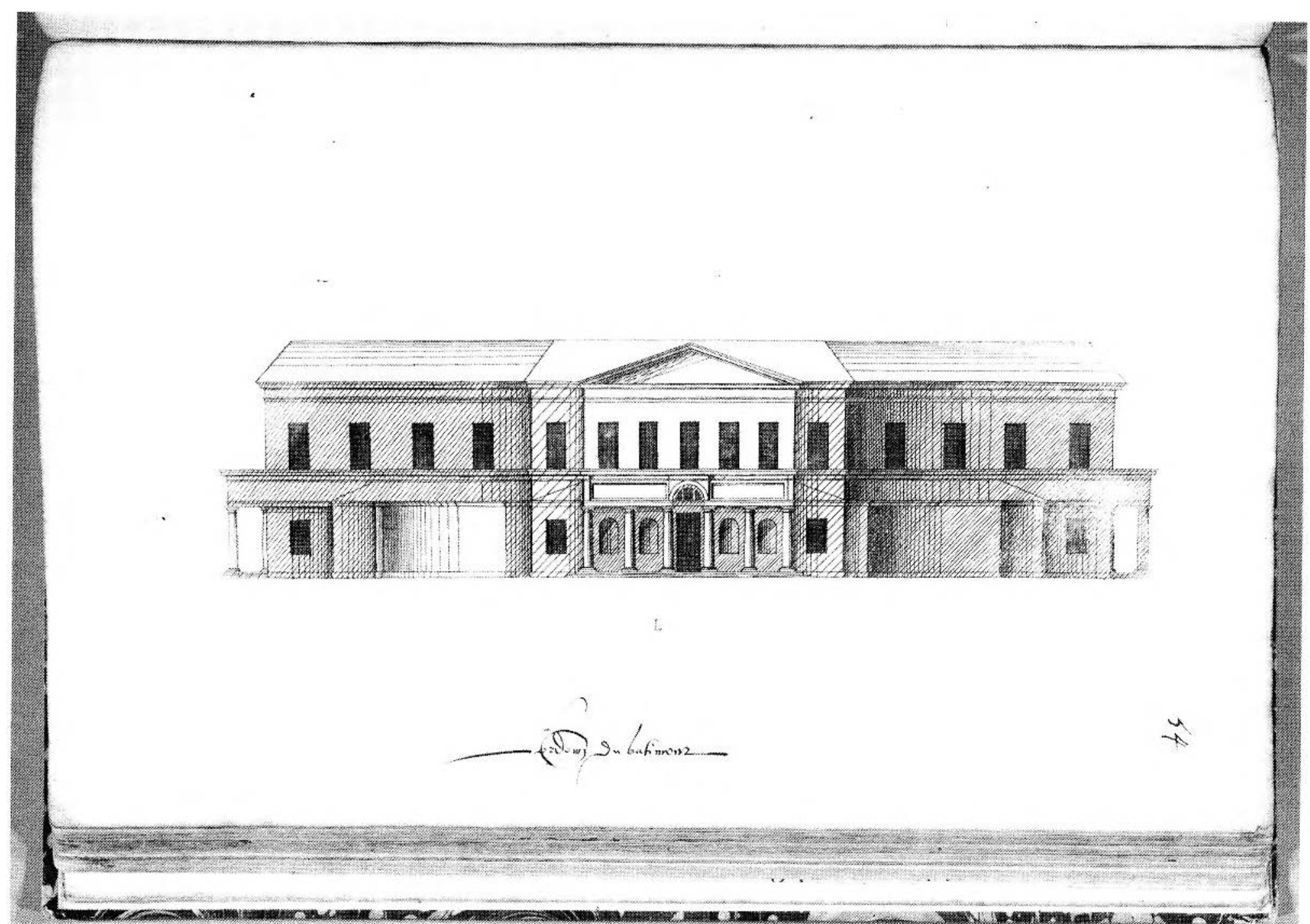




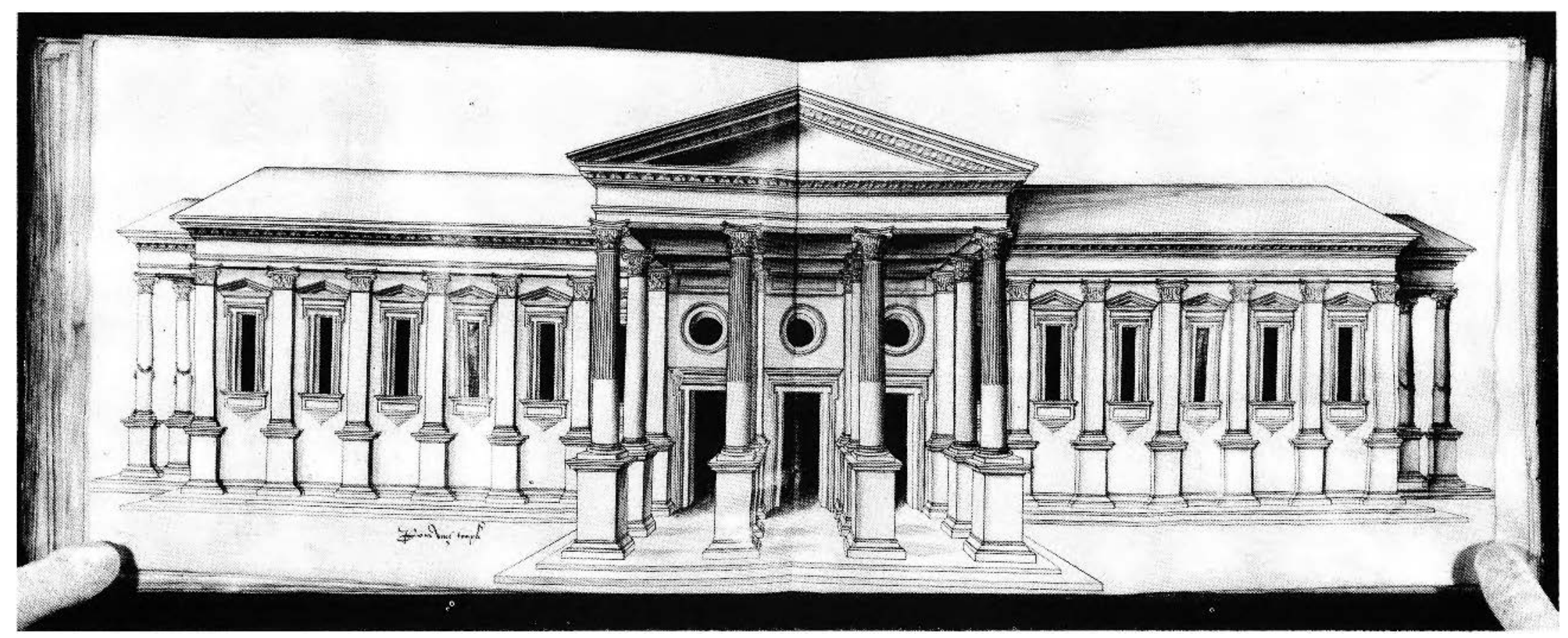

FiguRE 154. Workshop of Jacques Androuet Du Cerceau, Combined Frontal and Side Elevation of the Exterior of a Palace or Manor, pen, black ink, grey wash, over graphitc and stylus underdrawing on vellum, 1560-80, $43.6 \times 62.4 \mathrm{~cm}$ DR 1986:0108:065, Collection Centre Canadien d’Architecture/Canadian Centre for Architecture, Montréal. 


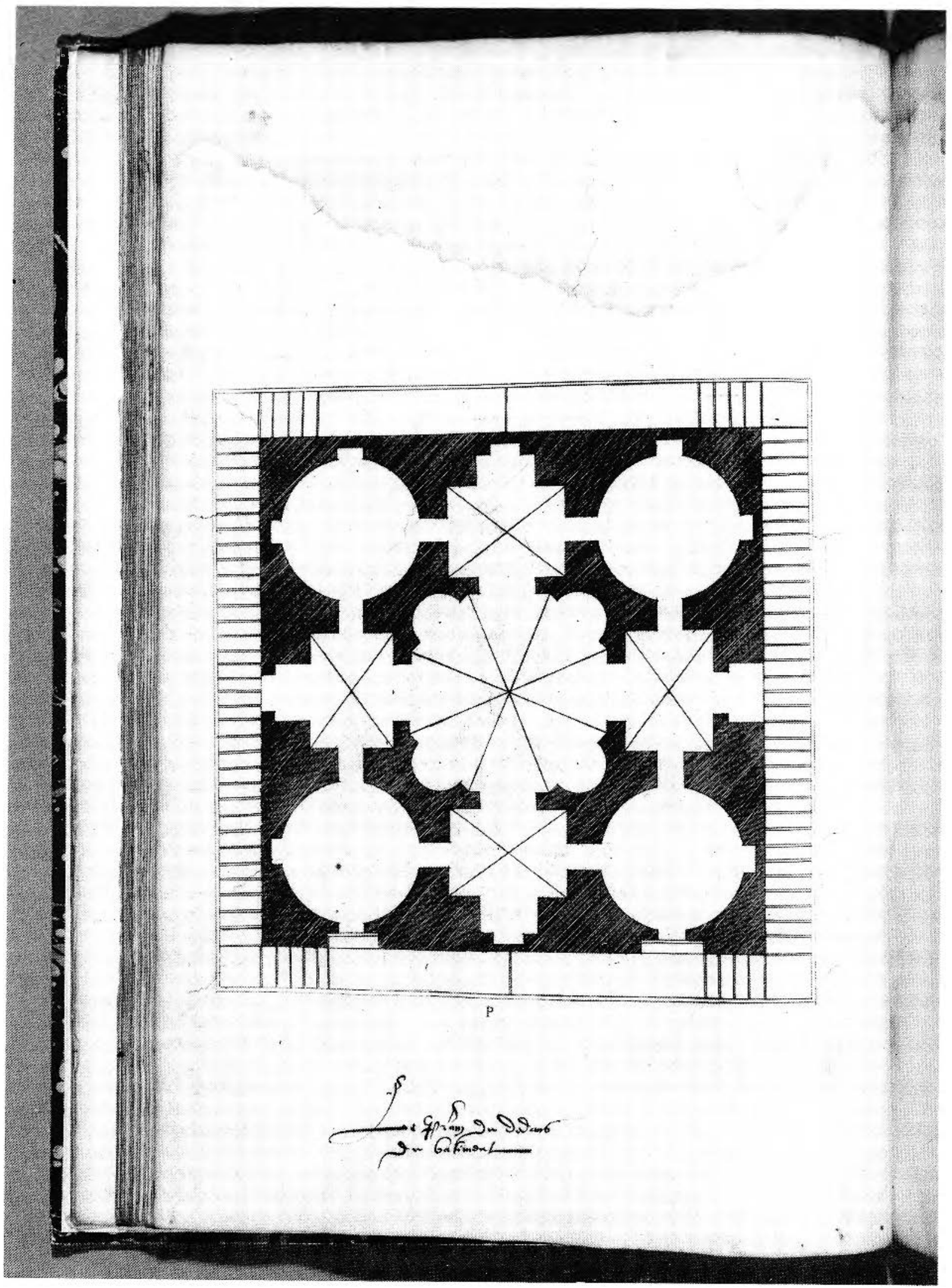

Figure 155. Workshop of Jacques Androuet Du Cerceau. Temples et habitations fortifiés, 1545-50, folio 40 verso, Ground Plan of Project P, engraving, $37.2 \times 24.2 \mathrm{~cm}$. IDX87-B9152, Collection Centre Canadien d'Architccture/ Canadian Centre for Architecture, Montréal. 


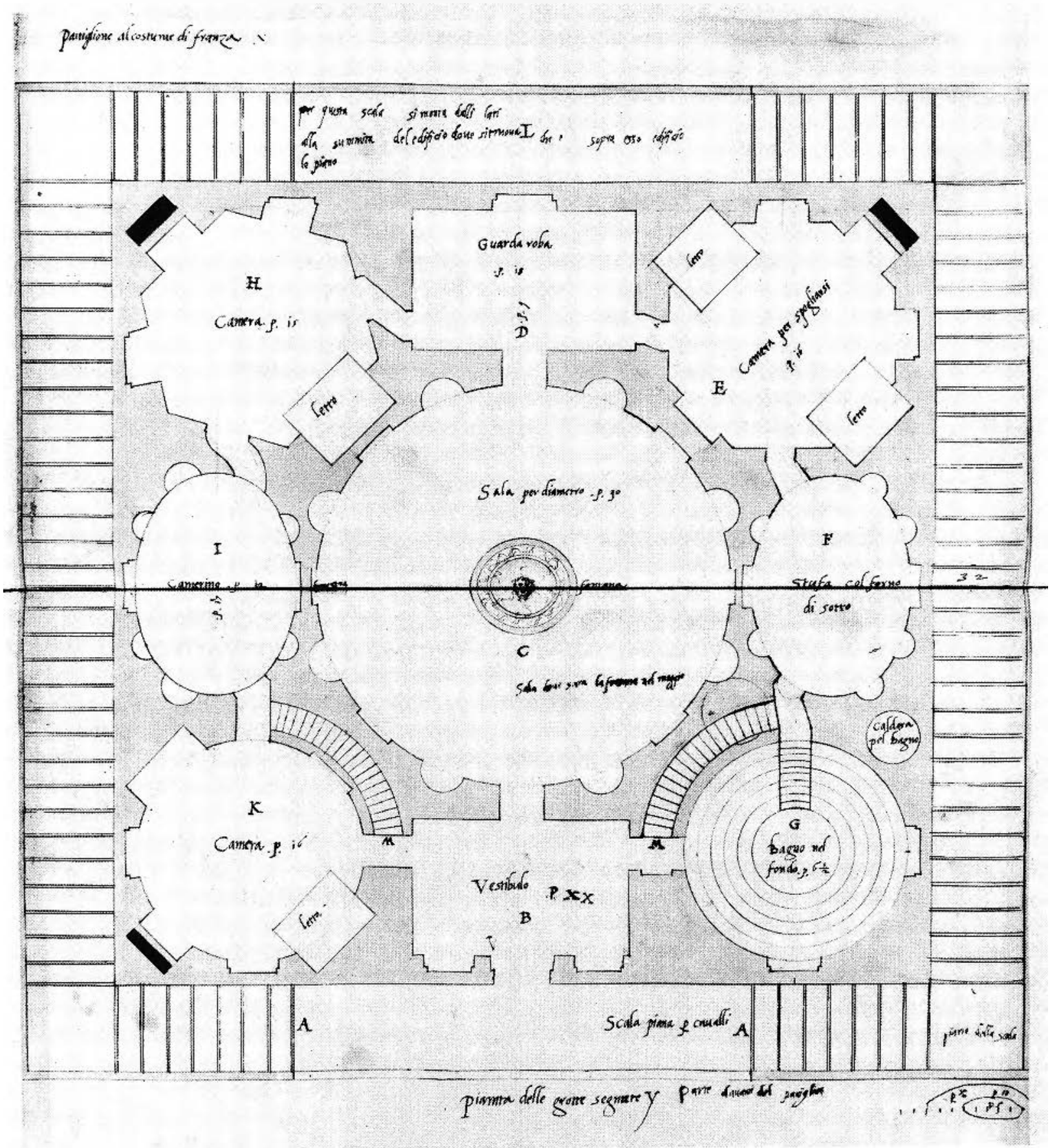

Fisure 156. Sebastiano Serlio, Bologna 1475 to Fontainebleau about 1553, Ground Plan for the ('rotte des Pins at Fontainebleau, pen, brown ink, brown wash over graphite and stylus underdrawing on laid paper, 1541-47, $38.5 \times 36.5 \mathrm{~cm}$. Folio xxxil of the manuscript for Book vi, On Domestic Archilecture, New York, Columbia Liniversity, Avery Architectural Library. 


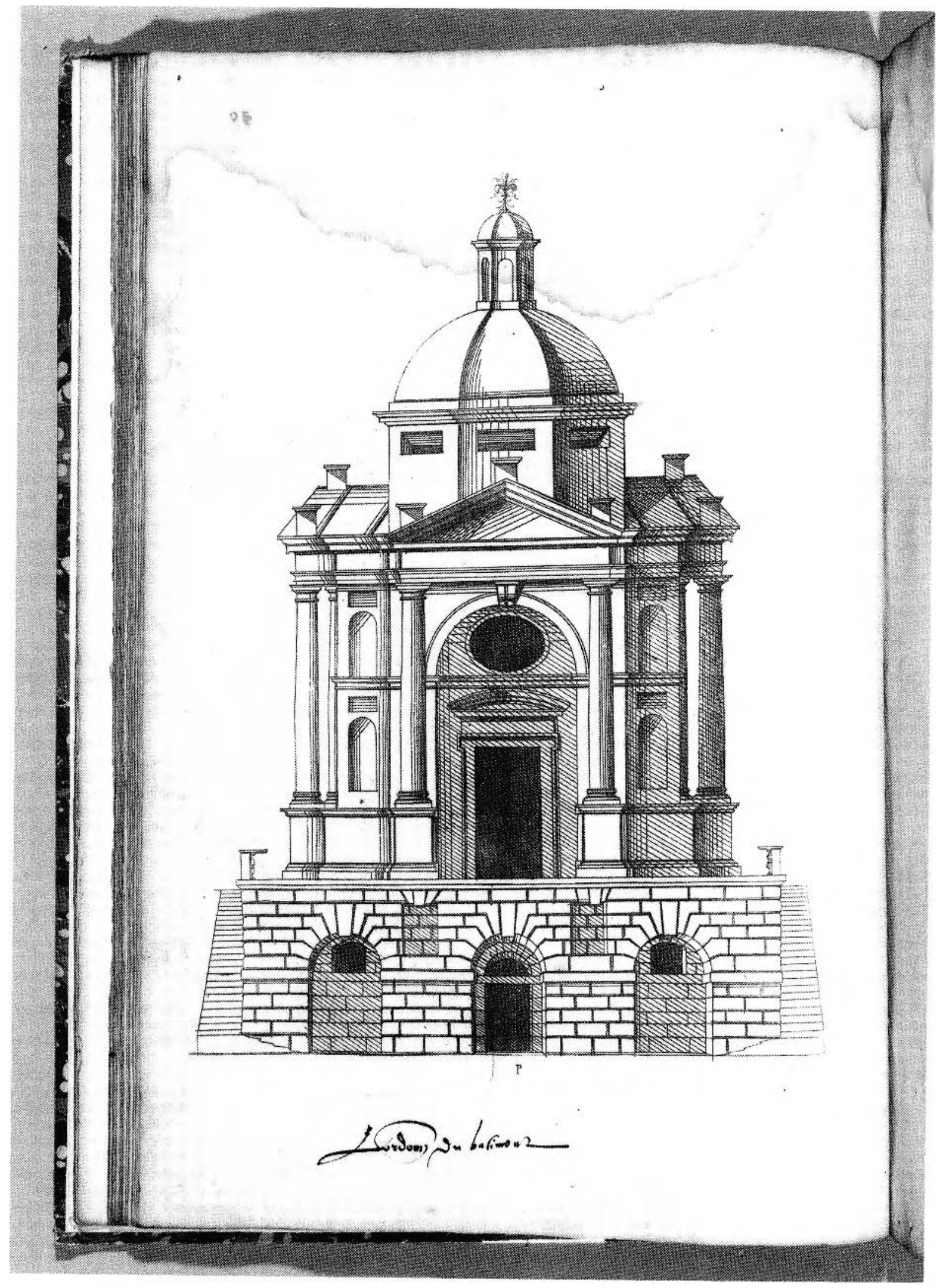

Fisiurt 157. Workshop of Jacques Androuet Du Cerceau, Temples et habitations fortifiés, 1545-50, folio 39 verso, Combined Front and Side Llevation of Project P, engraving, $37.2 \times 24.2 \mathrm{~cm}$. IDX87-139152, Collection Ccntre Cianadien d'Architecture/Canadian Centre for Architecture, Montréal. 

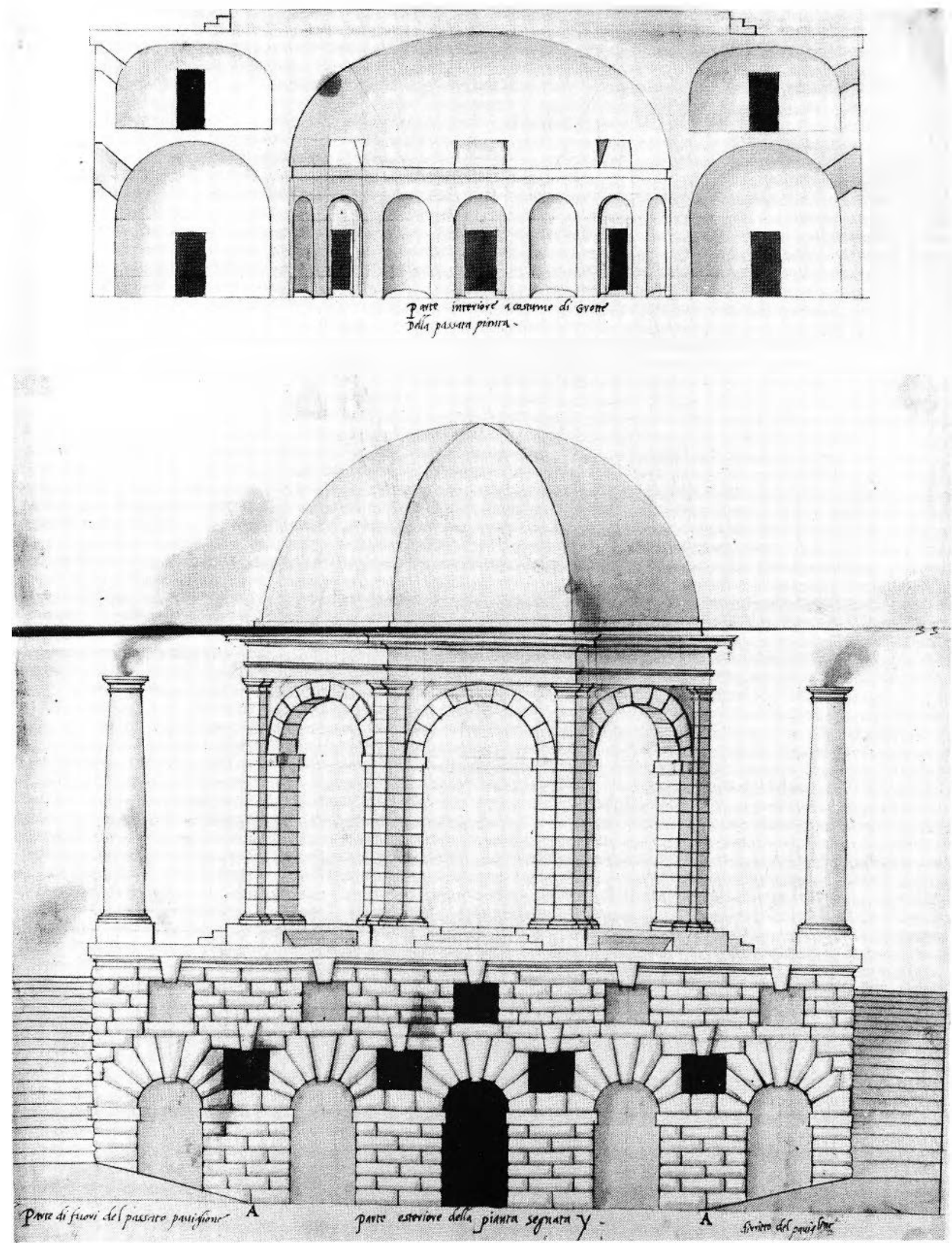

Figure 158. Sebastiano Serlio, Bologna 1475 to Fontainebleau about 1553 , Lilevation of the Exterior and View of the Interior of the Grotte des Pins at Fontainebleau, pen, brown ink, brown wash over graphitc and stylus underdrawing on laid paper, 1541-47, 38.5 × 36.5 cm. Folio xxxili of the manuscript for Book vi, On Domestic Architecture, New York, Columbia University, Avery Architectural Library. 


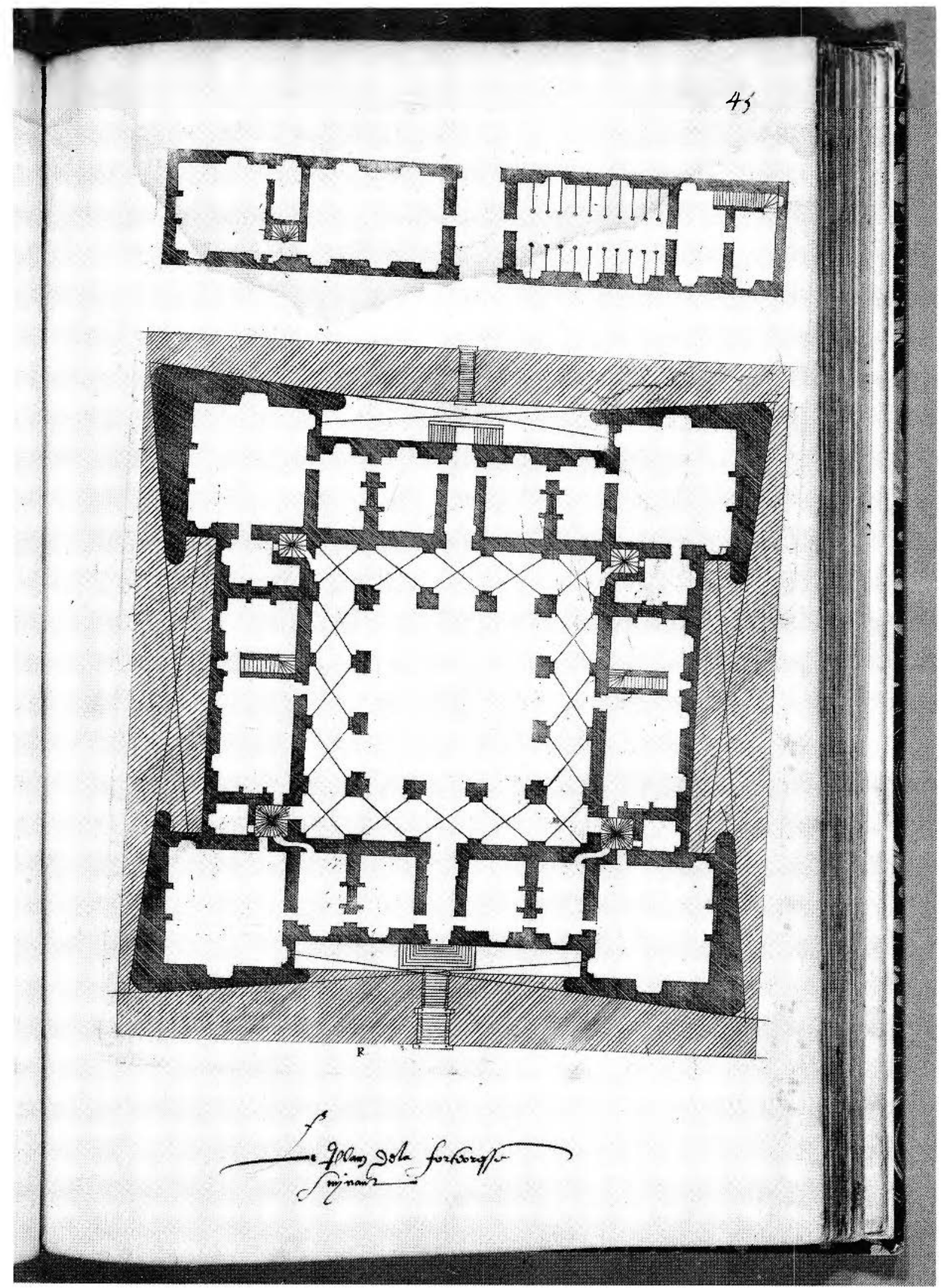

Figire 159. Workshop of Jacques Androuet. Du Cerceau, Temples et habitations fortifiés, 1545-50, folio 45 recto, Ground Plan of Project R, engraving, $37.2 \times 24.2 \mathrm{~cm}$. IDX87-B9152, Collection Centre Canadien d'Architecture/ Canadian Centre lor Architecture, Montréal. 


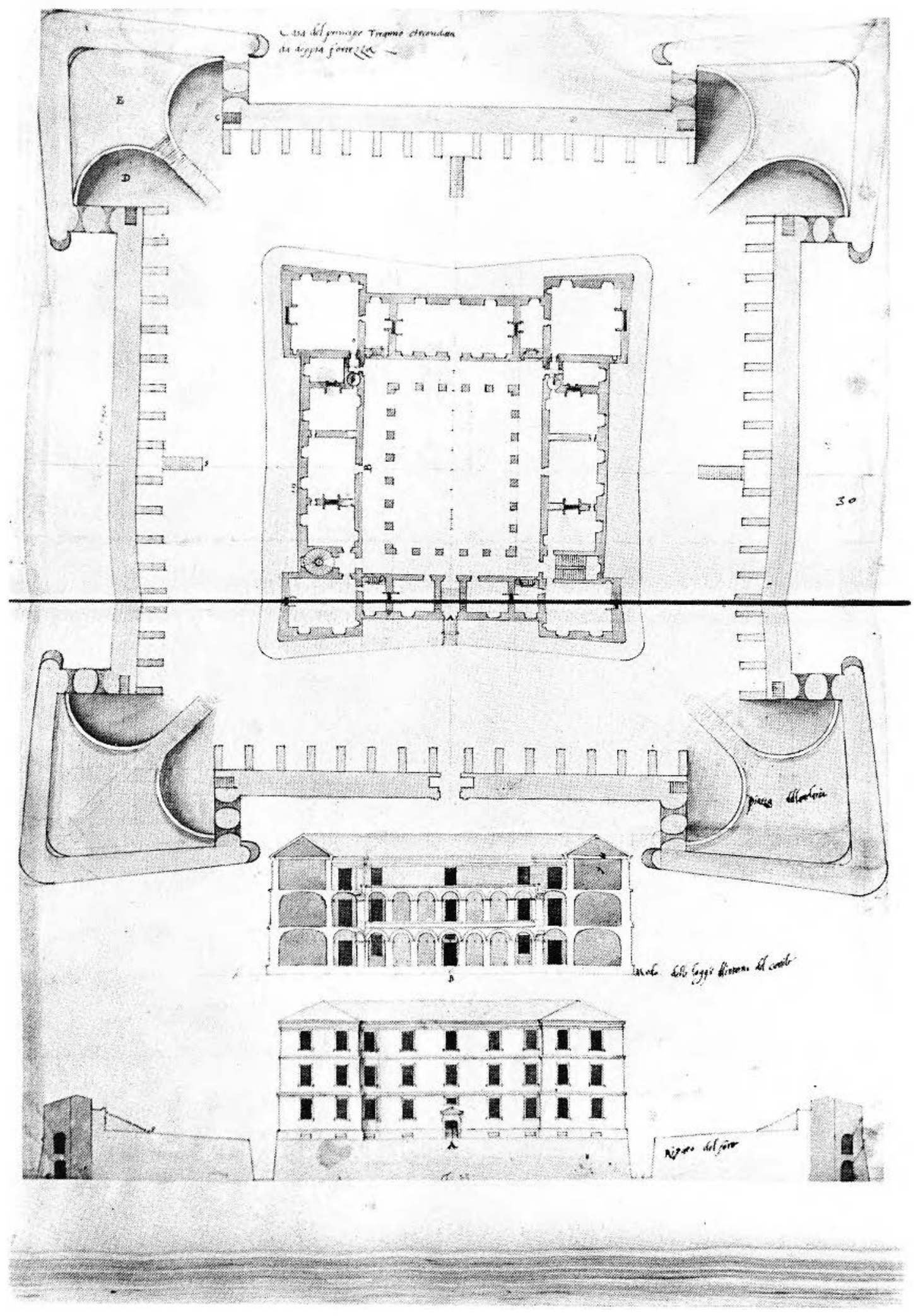

Figure 160. Sebastiano Serlio, Bologna 1475 to Fontainebleau about 1553, Ground Plan, Elevation and (iross-section of a Castle for a Tyrant Prince, pen, brown ink, brown wash over pencil and stylus underdrawing on laid paper, 1541-47, $38.5 \times 36.5 \mathrm{~cm}$. Folio xxx of the manuscript for Book vi, On Domestic Architecture, New York, Columbia University, Avery Architectural Library. 


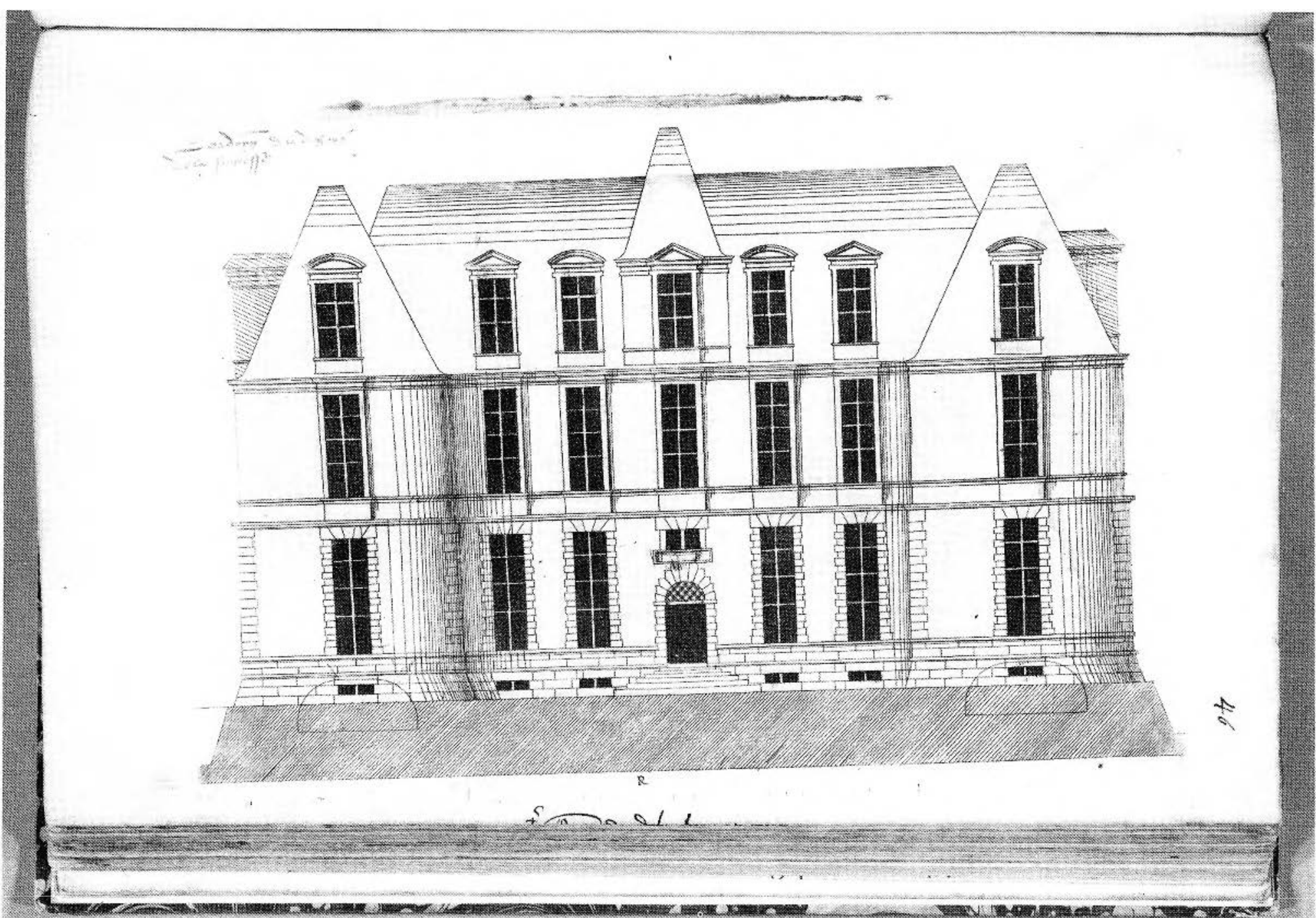

Frgitre 161. Workshop of Jacques Androuet Du Cerceau, Temples et habitations fortifiés, 1545-50, folio 46 recto, Elevation of the Facade of Project R, engraving, $37.2 \times 24.2 \mathrm{~cm}$. IDX87-139152, Collection Centre Canadien d'Architecture/Canadian Centre for Architcoture, Montréal. 


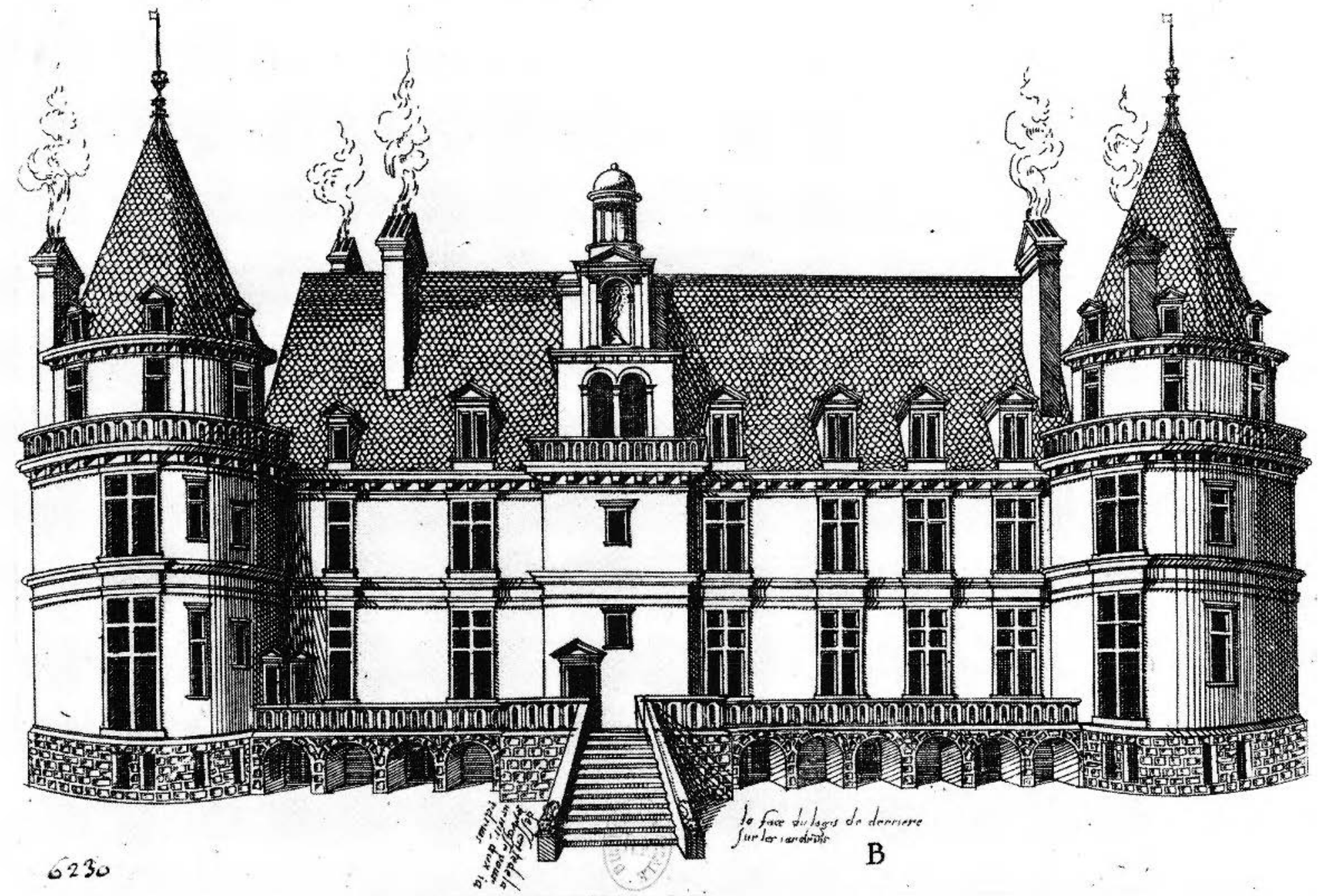

Figurf 162. Workshop of Jacques Androuet Du Cerceau, Petites habitations ou logis domestiques, 1545-50, folio 3 recto, Elevation of Manor B, engraving, $11.0 \times 15.3 \mathrm{~cm}$. Ed. 2c, Paris, Bibliothèque Nattionale, Cabinet des Estampes. 